Florida International University FIU Digital Commons

\title{
Imah on the Bimah: Gender and the Roles of Latin American Conservative Congregational Rabinas
}

Valeria N. Schindler

Florida International University, vschi001@fiu.edu

DOI: $10.25148 /$ etd.FI1 1042002

Follow this and additional works at: https://digitalcommons.fiu.edu/etd

Part of the Gender and Sexuality Commons, Other Religion Commons, Sociology of Culture Commons, and the Women's Studies Commons

\section{Recommended Citation}

Schindler, Valeria N., "Imah on the Bimah: Gender and the Roles of Latin American Conservative Congregational Rabinas" (2011). FIU Electronic Theses and Dissertations. 353.

https://digitalcommons.fiu.edu/etd/353 


\title{
FLORIDA INTERNATIONAL UNIVERSITY
}

Miami, Florida

\section{IMAH ON THE BIMAH: \\ GENDER AND THE ROLES OF LATIN AMERICAN CONSERVATIVE CONGREGATIONAL RABINAS}

\author{
A thesis submitted in partial fulfillment of the \\ requirements for the degree of \\ MASTER OF ARTS \\ in \\ RELIGIOUS STUDIES \\ by
}

Valeria Schindler

2011 
To: Dean Kenneth Furton

College of Arts and Sciences

This thesis, written by Valeria Schindler, and entitled Imah on the Bimah: Gender and the Roles of Latin American Conservative Congregational Rabinas, having been approved in respect to style and intellectual content, is referred to you for judgment.

We have read this thesis and recommend that it be approved.

Ana María Bidegain

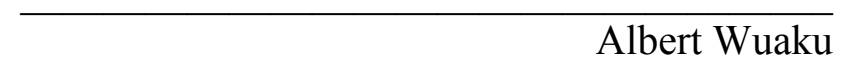

Oren Baruch Stier, Major Professor

Date of Defense: March 29, 2011

The thesis of Valeria Schindler is approved.

Dean Kenneth Furton
College of Arts and Sciences

Interim Dean Kevin O'Shea

University Graduate School

Florida International University, 2011 
(C) Copyright 2011 by Valeria Schindler

All rights reserved. 


\section{DEDICATION}

I dedicate this thesis to my parents, Daniel and Graciela Cababié for instilling positive values as well as love for Judaism in me since a very young age. To my husband Ozzie Schindler for all of his support and understanding. And to my daughters Daniela and Gylian Schindler for their unconditional love and incredible amount of patience. 


\section{ACKNOWLEDGMENTS}

First of all, I would like to express my deepest gratitude to the major professor on my thesis committee, Dr. Oren Baruch Stier who had faith in this project from the very beginning, providing a great deal of guidance and support. His knowledge on diverse areas of Judaism and his own passion for teaching were a great influence on my work. I am very proud and lucky to have been able to learn from him. I am thankful to Dr. Ana María Bidegain who as a Latin American immigrant to the United States, taught me the importance of recovering the history of women and religion in Latin America, because both matter. Her knowledge and expertise in the area of women in Latin America was a source of inspiration to me. And I am indebted to Dr. Albert Wuaku whose proficiency in fieldwork helped me shed light on my own experience, providing useful advice before and after my interviews. His insights on how to organize and contextualize all the information gathered were extremely helpful.

I would like to express my gratitude to the Tinker Foundation Inc. for awarding me a fieldwork grant in 2010. Without their generous financial support I would have not been able to personally meet the rabinas and interact with people of their congregations. Furthermore, I would like to thank Florida International University and the Latin American and Caribbean Center for introducing the Tinker Foundation Grant and for their support on this research. I am also grateful to the Department of Religious Studies and its professors for providing a stimulating and thoughtful curriculum.

I would like to express my appreciation to Rabinas Analía Bortz and Sandra Kochmann, who even though they are not part of this work (they are currently working in the United States and Israel), were extremely helpful and supported my research. Also 
Rabinos Ariel Avruj, Daniel Goldman, Abraham Skorka, and Rami Pavolotzky who generously shared their stories as well as their views on rabinas with me. I would also like to thank Rabino Adrian Gottfried for facilitating my introduction to Rabina PajeckiLederman and supporting this research.

And finally I cannot thank enough Rabinas Margit Baumatz, Silvina Chemen, Karina Finkielsztein, Graciela Grynberg, Luciana Pajecki-Lederman, Daniela Szuster, and Sarina Vitas who have been kind enough to share their personal stories, opening their hearts, congregations, and even their homes to me. I appreciate their participation and cooperation and they have been great supporters throughout my research. I would have not been able to present this work without them. 
ABSTRACT OF THE THESIS

IMAH ON THE BIMAH:

GENDER AND THE ROLES OF LATIN AMERICAN CONSERVATIVE CONGREGATIONAL RABINAS

by

Valeria Schindler

Florida International University, 2011

Miami, Florida

Professor Oren Baruch Stier, Major Professor

The aim of this research is to analyze the impact of gender on the work of Latin American rabinas within Conservative congregations in Latin America. The fact that women's roles in Latin America and in Judaism have been traditionally linked to nurturing and caring serves as the point of departure for my hypothesis, which is that the role rabinas play within their congregations is also linked to those traits. In this research I utilize a social scientific approach and qualitative methodology, conducting personal interviews with the rabinas. While this work proves that Conservative congregations in Latin America are gendered, my research demonstrates that this gendered division of labor does not have a negative impact on the work of rabinas. On the contrary, by embracing attributes of womanhood and motherhood rabinas become imah (mother) on the bimah (pulpit), educating, caring, and nurturing their congregations in a special and unique way. 


\section{TABLE OF CONTENTS}

CHAPTER

PAGE

INTRODUCTION 1

I. FEMINISM: Its Development, Ideas, and Influence ………….......................16

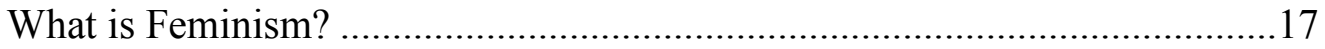

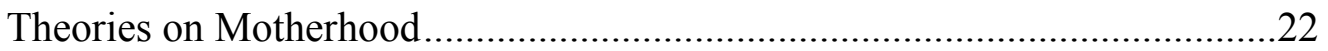

II. JUDAISM: Jewish Denominations and Jewish Feminism .............................26

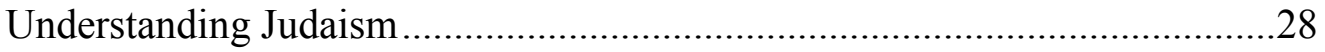

Understanding Jewish Denominations...............................................................

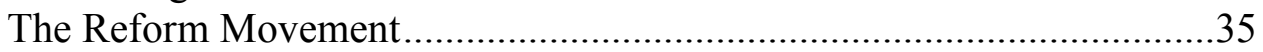

The Orthodox Movement...........................................................................36

The Conservative Movement....................................................................38.

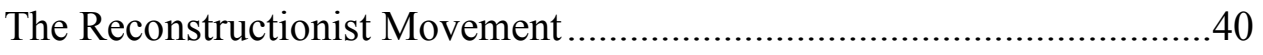

Jewish Feminism....................................................................................

Understanding the Basics of Jewish Feminist Thought......................................42

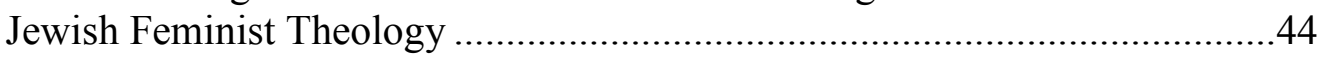

The Halakhah from a Feminist Perspective .......................................................46

Women and the Synagogue ...................................................................47

Women, Prayers, and Ceremonies .............................................................49

Women Ordained as Rabbis in the Conservative Movement ............................56

III. LATIN AMERICA: Understanding the Region in Context ...........................62

History of Women in Latin America ...............................................................64

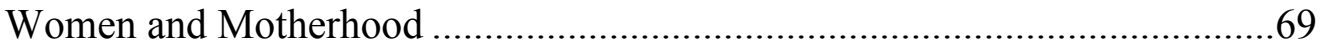

Feminism in Latin America: a Brief History ………………………................71

Jewish Migration to Latin America ..................................................................78

Religious Considerations: The Conservative Movement ................................85

The Seminario Rabínico Latinoamericano .......................................................8

IV. $\quad$ MEETING THE RABINAS: My Fieldwork Experience ................................93

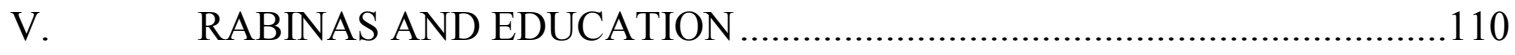

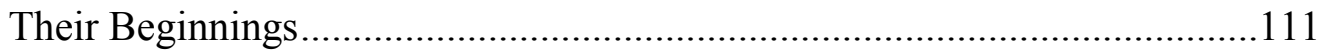

Educational Work as Rabinas ......................................................................115

The Importance of Women and Education ...................................................119

VI. RABINAS: Public Roles and Private Lives..................................................124

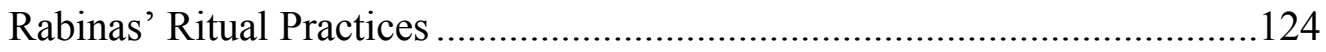

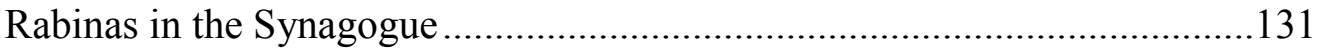

Rabinas and their Participation in Ceremonies ..............................................133 
Innovation of Rituals and Ceremonies.....................................................136

Rabinas Outside the Synagogue and their Congregations ..........................139

Rabinas on Family and Motherhood ...........................................................142

Rabinos' Thoughts on the Importance of Rabinas' Work ...........................150

VII. ME, A FEMINIST? Rabinas' Understandings of Feminism.......................154

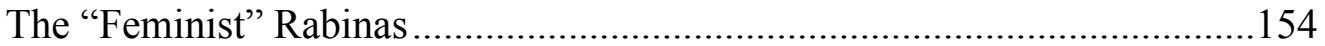

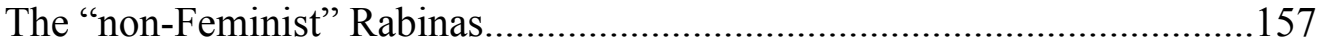

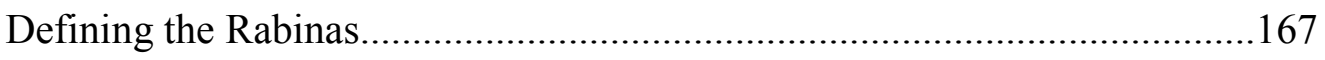

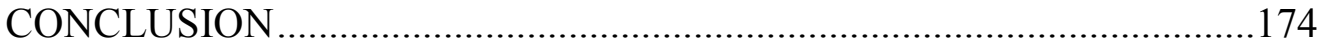

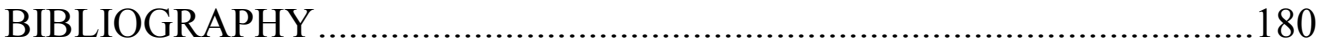




\section{LIST OF FIGURES}

FIGURE

PAGE

1. Women's enfranchisement dates in Latin America ................................................68

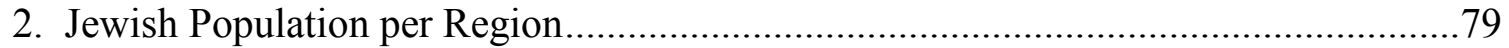

3. Total and Jewish Populations of Latin America, by Country 1960 and 2005 ...........84

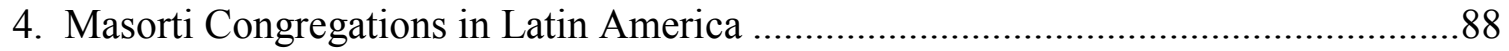

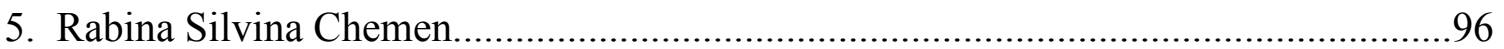

6. Rabinas Sarina Vitas and Margit Baumatz ..................................................... 100

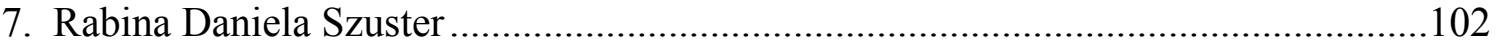

8. Rabina Luciana Pajecki-Lederman and Rabino Adrian Gottfried ............................104

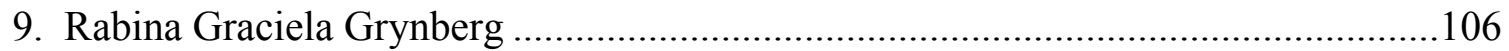

10. Rabina Karina Finkielsztein and Rabino Alejandro Avruj ..................................108 


\section{Introduction}

The ordination of women as rabbis within the Conservative movement is a fairly new phenomenon. The first ordination took place in the United States in May of 1985 when Amy Eilberg became “Ha'Rav Chana Beyla," rabbi, teacher, and preacher in Israel (Nadell 1998, 214). Nine years later, in August of 1994, Margit Baumatz became the first woman ordained as rabbi at the Seminario Rabínico Latinoamericano in Buenos Aires, considered the academic, cultural, and religious center of the Conservative Jewish Movement for Argentina and Latin America. Two months later, in October of 1994, Analía Bortz was ordained at the same institution. Between 1995 and 2006 seven other Latin American women were ordained at the Seminario and one at the Jewish Theological Seminary (JTS) in New York City. Currently, ${ }^{1}$ three of them are working in congregations in the United States and Israel, six in Latin American congregations, and one is retired. In September of 2009, I visited the library of the Seminario Rabínico Latinoamericano in order to conduct research on women ordained as rabbis in Argentina. The library claims to be the "most complete and accurate in Judaic science in Latin America" (Baril), however I was unable to find scholarly reports documenting this important milestone, nor any information on women ordained as rabbis within the Conservative movement. There were several newspaper articles hung on the walls announcing some of the ordinations that took place at the Seminario, but no other source of information. In contrast, stories about women's fight for equal rights within Conservative Judaism in the United States and the ordination of the first woman rabbi in

\footnotetext{
${ }^{1}$ This research was written between the end of 2010 and the beginning of 2011.
} 
1985 have been documented in books, articles, scholarly works, and even textbooks (Falk; Geller; Gordis; Nadell; Novak; Pearlmutter; Rubin Schwartz). I was intrigued by the lack of information on the topic and sought to explore the reasons behind it and to make the stories of Latin American rabinas ${ }^{2}$ (women rabbis) known.

There are seventy-one Congregations belonging to the Masorti movement ${ }^{3}$ in Latin America, and only six rabinas are currently working in them. The lack of labor opportunities for rabinas in the Latin American Conservative movement ${ }^{4}$ can be attributed to the enduring influence of patriarchal ideas in Latin America, like that the man is the breadwinner and the one active in the public sphere, while the woman fulfills domestic roles and is active in the private sphere. ${ }^{5}$ These ideas facilitate persistent stereotypes about men and women in Latin American culture. Moreover, domestic structures are reproduced within the workplace (Acker 1990; Abassi and Lutjens; Craske). Motherhood, which has always been closely associated with womanhood in Latin America, can constrain women and contribute to their unequal treatment (Chant and Craske; Craske; Stepan). Additionally, in traditional Judaism the role of the woman

\footnotetext{
${ }^{2}$ I will clarify below.

${ }^{3}$ Conservative Congregations outside the United States are affiliated with this movement. For the purposes of this work, I will use Masorti and Conservative as synonyms. The World Council of Conservative/Masorti Synagogues (Masorti Olami) "builds, renews and strengthens Jewish life throughout the world, with efforts that focus on existing and developing communities in Europe, Latin America, the Former Soviet Union, Africa, Asia and Australia." It conducts activities within the context of the overall Conservative/Masorti movement "in close cooperation with brothers, sisters and affiliated organizations in North America and Israel” (DevArt 2010).

${ }^{4}$ This fact was emphasized by all the rabinas I interviewed who reflected on their own frustration with the issue. Rabina Baumatz explained to me that as director of rabbinical placement for Latin America it was extremely hard for her to find jobs in Latin American congregations for rabinas.

${ }^{5}$ Even though nowadays women in Latin America participate and are active in the public sphere.
} 
as mother and wife is extremely important, for at the Jewish core is the family unit (Adler; Greenberg; Hyman). I believe these stereotypes are also emphasized in religious organizational structures in Latin America when it comes to the distribution of tasks within the institution. These stereotypes are so pervasive that each rabina is an "Imah on the Bimah" (mother on the pulpit), with all the attributes and traits that "mother" comes with.

When analyzing the roles and the distribution of tasks within an organization, gender is an extremely important analytical tool, and emerged as such in the late twentieth century (Scott, 1066). Gender is the primary way in which people are categorized, perhaps because it is manifested in all aspects of our lives - from the way we dress, to our daily activities, even to boxes we check off on official forms. This categorization is usually made on the presumption of biological differences and based on observations, therefore "our social understandings about gender differences thus enter into sex categorization" (Acker 1992, 566). In the last few decades, the study of gender has been expanding thanks to the impact of research in the social sciences and humanities. After World War II, Simone de Beauvoir wrote The Second Sex in which she argues that female subordination is a consequence of patriarchy as a historical event rather than a natural cause. She asserts that "one is not born, but rather becomes a woman"6 (Barrancos, 13). De Beauvoir defines woman as the Other and man as the One, or the norm, who created the cult of 'feminine' to maintain the oppression of women. Therefore women are "taught how to be women, i.e., passive, object-like, free beings

\footnotetext{
${ }^{6}$ My own translation.
} 
mystified into believing that they are confined to particular 'natural' roles which limit freedom" (Scholz, 68).

Feminists like de Beauvoir felt the need to differentiate between the biological identity associated with each $\operatorname{sex}^{7}$ and the ways those differences were treated within society (Freedman, 18). Thus sex is related to nature while gender is associated with nurture (Acker 1992, 565). It is important to understand that female gender is not synonymous with "woman." As explained in the Encyclopedia of Religion, gender studies should not relate to one gender only; indeed, there are growing movements of "men's studies" as well as of “women's studies." Gender studies were first developed in the social sciences in the 1960s and 1970s and aimed to investigate human sexual differences and roles, beginning with a distinction between "sex" and "gender." While sex came to mean the biological differences between man and woman, gender distinguished between the "historically and culturally developed interpretations of what it means to be a man or a woman in different societies and cultures" (King, 3296). What is assumed by this formulation is that "[s]ex is real and gender artificial or sex is an ahistorical (outside of history) natural fact of human nature, while gender is a social and historical construction built upon the natural fact" (Juschka, 230). Understood in this way, gender becomes a category for analysis related to social and historical issues, while sex is something fixed and determined by nature.

Gender is used to determine social relations between the sexes, and its use "explicitly rejects biological explanations, such as those that find a common denominator

\footnotetext{
${ }^{7}$ These can also be defined as the "natural" differences between men and women.
} 
for diverse forms of female subordination in the facts that women have the capacity to give birth and men have greater muscular strength" (Scott, 1056). Thus gender becomes an element of social interaction derived from perceived differences between the sexes and becomes the primary signifier of power in relationships. On the other hand, sexual differences are also set by society, which determines roles determined by sex. Joan Acker indicates that feminist work had produced an enormous amount of research and literature showing that gender divisions and pattern of power, "while extremely diverse, exist wherever one looks" (Acker 1992, 567).

Recognizing gender as a category of analysis is important for the purposes of this work because it helps in the understanding of gendered division of work within institutions. It is also a helpful tool for explaining why I have chosen to use the Spanish word, "rabina," when referring to Latin American women rabbis. The term "woman rabbi" is linguistically incorrect. Spanish words are gendered, so in keeping with the spirit of this work, I shall use "rabina" for a woman rabbi and "rabino" for a man rabbi. Nevertheless, it is interesting to note that the term "rabina," while widely used in everyday language, does not exist in the Diccionario de la Real Academia Española (Real Academy Spanish Dictionary). The term "Rabba" (female of Rabbi in Hebrew) does not exist either. ${ }^{8}$ I have chosen this terminology as both a way of conveying sex and gender

\footnotetext{
${ }^{8}$ Rabina Chemen explained to me that even though some women have chosen to have the term "rabba" written in their Hebrew ordination, she decided to have "Rav be Israel Titkarev" written in her Hebrew ordination, meaning "and she will be called rabbi," because she wanted to be something that exists.
} 
simultaneously when referring to women rabbis and as a way to establish a sense of equality ${ }^{9}$ between both men and women rabbis.

One question I sought to answer with this study was whether rabinas are treated differently than rabinos because Conservative congregations in Latin America are gendered. Furthermore, it would be hard to define the rabinas as feminists, or not, because the term itself is understood differently in Latin America (Craske). It must be considered that the Latin American culture and Jewish background of rabinas is part of the construction of their identities, and that those identities are associated with and defined by different variables than those variables present in the United States. In this case, womanhood and motherhood act as positive attributes that enable rabinas to fulfill certain roles and perform certain tasks within their congregations. Therefore the work they perform is validated through their womanhood and motherhood (Belucci; Montesino; Nadell).

To understand the issue of gendered organizations I am using Joan Acker's theory, in which she explains that organizations are said to be gendered when "advantage and disadvantage, exploitation and control, action and emotion, meaning and identity, are patterned through and in terms of a distinction between male and female, masculine and feminine" (Acker 1990, 146). No organization is gender neutral, and Acker argues that hierarchies assume a disembodied and universal worker who is actually a man, and that

\footnotetext{
${ }^{9}$ Rabbi Lynn Gottlieb shows her discomfort in her essay, "Women Rabbis in Spiritual Leadership," saying that despite the apparent consensus among women rabbis using the term "rabbi" when referring to themselves, the term is masculine. She therefore finds a good deal of irony in using the masculine form of identification "so that [women rabbis] can maintain a sense of our equality" (Gottlieb, 31-32).
} 
images of male bodies and masculinity pervade organizational processes, marginalizing women, favoring men, and contributing to the maintenance of gender segregation within the organization (Acker, 1990; Acker, 1992). She defines the term "gendered institutions" as being present in the "processes, practices, images and ideologies, and distributions of power in the various sectors of social life," concluding that "Most of the institutions in the United States and other societies are organized along lines of gender, in which women have been absent." However, she argues that the only institution in which women have had a central, defining, although subordinate role, is the family (Acker 1992). Acker argues that interaction between individuals is the medium for institutional functioning, decision making, and production. This way, people "do gender" as they do the ordinary work of the institution. Each institution has internal processes in which individuals "engage as they construct personas that are appropriately gendered for the institutional setting" (Acker 1992, 568). Religious congregations are not only places of worship, but places of work as well; therefore I consider them gendered institutions. My main question is to what extent Conservative congregations' structures in Latin American have been formed by and through gender. I propose that Conservative Congregations in Latin America are gendered and as such, there are gendered expectations for rabinas' who work within the congregation and for the way tasks are carried out by them. Since Latin American and traditional Jewish cultures tell us that women are nurturers in charge of caring and educating others, caring work becomes gendered work and considered to be a responsibility of women. In this context I argue that rabinas working within Conservative congregations in Latin America tend to reenact the traditional role of women within their 
congregations, becoming "mothers" of the congregation, and working as educators who nurture and protect their congregants with a "sensitivity" that they feel men lack.

In addition to Acker's theory, I will rely on Stuart Hall's theory of cultural identity because it helps to make sense of the rabinas' identification with particular roles. In his article, "Cultural Identity and Diaspora" Hall makes the point that cultural identity is a matter of "becoming" as well as "being." He recognizes that "there are also critical points of deep and significant difference which constitute 'what we really are;' or rather- since history has intervened — "what we have become"” (Hall, 225). Furthermore, "Far from being grounded in a mere 'recovery' of the past, which is waiting to be found, and which, when found, will secure our sense of ourselves into eternity, identities are the names we give to the different ways we are positioned by, and position ourselves within, the narratives of the past" (Hall, 225). Instead of using culture to identify oneself with what historically has been part of our heritage, we have to consider other events in history. Therefore we cannot generalize Jewish cultural identity as being the same throughout the entire world and we cannot generalize the history of women as being the same either. This mix of Latin American culture and Conservative Jewish woman helps construct an image of a rabina that is different from that of a woman rabbi in the United States. While the scope of this research is not a comparison between the two, since women rabbis in the United States were the precursors of rabinas, I think is important to understand the reasons behind their similarities and differences.

There are numerous works written on gendered organizations (Acker 1990, 1992; Chant and Craske; Gorlier and Guzik; Lebon and Maier), as well as on Jewish feminism 
(Adler; Geller; Greenberg; Grossman and Haut; Plaskow, Safra), on women in Latin America (Bidegain; Femenías; Navarro and Korrol; Jaquette; Leacock), and on Jews in Latin America (Elkin Laikin; Seymour Liebman; Monk), but there has been no attempt to explore the intersectionality ${ }^{10}$ of these subjects. The aim of this thesis is to determine how social and cultural factors related to the role of women in Latin America and in traditional Judaism influence the work rabinas perform within their congregations, the perception others have of them, and how that role influences the dynamics of the duo "rabino-rabina" of the congregation.

Theoretical tools utilized in my work come from the fields of religious studies and sociology. Since human socio-cultural behaviors are based on social meaningsintentions, motives, rules, beliefs, etcetera, I utilize a social science approach giving me access to the "meanings" that guide human behaviors in these specific contexts. I use a qualitative methodology in which the data come from personal interviews conducted with the seven rabinas and with the rabinos who work with them. ${ }^{11}$ I use an auto-ethnographic approach to analyze the data as an attempt to practice self-reflexivity, meaning that I place myself within the social context by connecting the personal and the cultural

\footnotetext{
${ }^{10}$ I use this term here as it is used in the fields of women studies, feminist theory, and literary criticism, in which the intersections or intersectionalities of race, class, and gender are accepted realities (Holvino, 248).

${ }^{11}$ In September of 2009, upon approval from the FIU Institutional Review Board, I interviewed Rabinas Chemen, Vitas, and Baumatz for a research paper for one of my graduate courses. That December I was awarded a Tinker Field Research Grant to perform fieldwork in Latin America; with a draft of this proposal I obtained approval from the IRB and traveled to Costa Rica, Brazil, and Argentina to interview the rabbis. On this trip I interviewed Rabinas Szuster, PajeckiLederman, Grynberg, Baumatz, Vitas, and Finkielsztein, and Rabinos Skorka, Pavolotzky, Goldman, and Avruj. I was also able to interact with members of Congregation B'nei Israel in Costa Rica, and Comunidad Bet-El in Argentina.
} 
(Christiane). In this thesis I use a first person narrative to show how people act and react in different circumstances, inserting my own voice as well as those of the rabinas' in the text. I believe it is important to do so because my own history as a Latin American Jewish woman raised within the Conservative movement is part of the framing of this research. The voices of the rabinas helped me to analyze the information, and I have tried to echo the passion they showed when sharing their stories with me, including their struggles for acceptance, the work they perform, and the love they feel for Judaism and education. Each one of them has a different story that helps construct a collective Latin American feminine identity within Conservative Judaism, enriching it in a very unique way. The conclusions produced by this work are part of my own analysis and understanding of the rabinas and their words, therefore I can only be responsible for that.

In order to better understand the circumstances surrounding the rabinas as well as some concepts and terms I repeatedly use throughout my work, I need to explain several concepts before beginning with their stories. Thus this work is divided in two main parts; in the first part (chapters I through III), I explain concepts and theories in the areas of feminism, Judaism, and Latin America. This will enable the reader to understand my analysis and interpretations of the rabinas' discourses in the second part of this work.

In chapter I, I deal with issues of feminism. I will begin by providing a general summary of its development as a movement including its main ideas, and the influence those ideas have in the fight for women's rights. I will then provide a historical timeline of its development through a description of feminism's beginnings and subsequent evolution marked by different "waves." Feminism is not a unified movement and 
therefore encompasses different approaches molded by several schools of thought. In an attempt to understand the main differences between theories, I will provide a description of the most relevant differences and some of the theories they produced. I will end the chapter with some theories on motherhood produced within the framework of several schools of thoughts. Knowing these theories is important because it will enable the reader to understand, in a theoretical and systematic way, the thoughts rabinas share regarding motherhood and womanhood and how these roles help make them better rabinas.

Conservative Judaism is an integral part of this work, but in order to understand its conception and history, it is important to first understand Judaism in general. In chapter II, I will first explain basic notions of Judaism, including concepts that are essential to the understanding of Conservative Judaism such as Halakhah (Jewish law) ${ }^{12}$ and its interpretation, as well as some rituals and customs. I will then provide a chronological timeline of the development of Judaism including the main characteristics of each period, and the role Jewish women have played accordingly. Once the basics of Judaism are covered, I will explain the circumstances under which the Reform, Reconstructionist, Conservative, and Orthodox movements were established and the main differences between them, including the dates when women were able to receive ordinations as rabbis. The second part of chapter II deals with Jewish feminism and its impact on women's search for equality within the religion. I will begin by defining the goals of Jewish feminism and the dates and circumstances of its development. Jewish feminism impacted different areas of the religion in different ways. I will continue by

\footnotetext{
${ }^{12}$ Halakhah-literally, the path that one walks - is the Jewish law and is an integral part of the religion that comes from the Torah, as well as laws institutionalized by rabbis, and customs.
} 
noting the areas in Judaism impacted by Jewish feminist thought as well as how and what changes were implemented as a consequence. The chapter will cover feminist theology and its impact in Biblical and post-Biblical interpretation through the lens of feminist halakhic (from Halakhah) interpretations that ultimately enabled the ordination of women as rabbis. Furthermore those halakhic interpretations facilitated other changes for women within the synagogue in order to provide an egalitarian position such as, for example, changes and innovations in rituals and ceremonies. I will end the chapter dealing with the issue of women's ordinations: its beginnings, the first women to drive the issue, changes that were necessary for the ordination of women, and when the first ordination took place. Finally I will present a chronological account of events and issues related to the ordination of the first woman rabbi, Amy Eilberg, in the Conservative movement in the United States.

Chapter III will contextualize chapter I by placing feminist concepts and ideas within a Latin American framework. I will begin by explaining the history and the progress of women's place in Latin America. In doing so, I will explore the subjects of womanhood, motherhood (in the continent) and Latin American feminism. In the second part of Chapter III, I will explore the issue of Jewish migration to the continent and the development of the Conservative movement in the region. In this section, I will recount the story of the establishment of the Seminario Rabínico Latinoamericano, its function, and the circumstances surrounding its creation. Explaining the Seminario's role is vital to understanding the way Conservative Judaism works in the region and its support of the ordination of rabinas. 
The first two chapters provide basic information and theory establishing a foundation for chapter III, in which I will place he information in the context of Latin American. Understanding feminism, Conservative Judaism and their interplay in Latin America will enable me to set the stage for chapter IV in which I will introduce the rabinas. In that chapter, I will detail our encounters, the circumstances in which we met, how those circumstances influenced my interaction with them, and provide a brief background on each rabina. This chapter is shaped by their voices and feelings about the decision to become rabinas, the support (or not) they received throughout their studies, and the reception they were given by their respective congregations after their ordinations.

Chapters V, VI, and VII will explore the various roles and tasks of rabinas within their congregations as well as outside the Jewish community. Education has been a predominantly female profession in Latin America and Judaism, and the rabinas are no exception. Besides affording them higher status in society, education plays an important role in their day-to-day lives. In chapter V, I will examine the influence of education on the rabinas and how that motivated them in their decisions to join the rabbinate. I will continue by describing the work they do as educators from their rabbinical position. I will end the chapter by analyzing the parallels between the history of education and women within the Conservative Movement and the history of the rabinas. To do so, I will compare the experiences of rabinas with those of women in the United States, especially of feminists pushing the issue of women's ordinations. 
In chapter VI, I will cover other functions rabinas perform within and outside their congregations and the impact those functions have on the way congregants see them. I will cover issues such as religious and ritualistic practices of rabinas, their role in the synagogue and prayers, and activities they perform as rabinas in non-Jewish contexts. I will end the chapter with their own thoughts on motherhood. This final exploration will help me support the thesis that gender becomes extremely important for rabinas, and that motherhood distinguishes them from rabinos. Furthermore, I include rabinos' views on the importance of having rabinas because their views confirm the practice of gender differentiation in the assignment of tasks. As explained in chapter III, in Latin America, the designation of roles based on gender are rooted in the culture.

I consider feminism an important part of my research, because the movement's impact resulted in greater rights and equality for women in Latin America and Conservative Judaism. Throughout my interviews I was able to learn that the majority of rabinas currently working in Latin America do not consider themselves feminists in the sense feminism is understood in the United States. Moreover, they expressed harsh words concerning the movement. In chapter VII, I will attempt to reconcile their work-which I consider to be feminist—with their "non-feminist" claim and redefine what and the rabinas are.

In the last chapter, I will provide conclusions and suggest related topics for further research. Although many feminists have argued against the practice of gender differentiation within workplaces and organizations, I believe that the case of rabinas in Latin American Conservative congregations is different, because gender differentiation is 
what facilitates their present leadership positions. Each rabina is an "Imah on the Bimah," mothering her congregation with love and passion. My work is an attempt to present the lives, struggles, and fights of rabinas, and to demonstrate that their embracing traditional characteristics of womanhood earns them the respect of peers and their congregations, as well as a position of leadership. 


\section{Chapter I}

\section{Feminism: Its Development, Ideas, and Influence}

Feminism has been around for many decades encompassing a diversity of ideas, many of which are not unified within the movement. The beginnings of the Feminist movement can be traced to Europe and North America, but its ideas influenced women's movements worldwide, including Jewish and Latin American women. As a result of the influence of second-wave feminism, the Reform, Conservative, and Reconstructionist movements became more inclusive of women. ${ }^{13}$ During the 1980 s, feminist ideas even penetrated Orthodoxy, influencing some women within that movement as well. ${ }^{14}$ In order to better understand the changes within Latin American Judaism triggered by the feminist movement, chapter I will provide a brief introduction to feminism. Since the diversity of ideas within the movement makes providing a general definition of the term very difficult, I will attempt to define feminism by outlining some of its main ideas and the waves of its historical progress, as well as some schools of thought within the movement. I will also discuss feminist theories on motherhood and how they play out in the lives of modern women. Theories on motherhood will be useful to understanding the role of rabinas within their congregations.

\footnotetext{
${ }^{13}$ In her essay, "Women and American Judaism," Nadell asserts that the impact of social revolution is evident in the empowerment of Jewish women and the changes they effected toward greater inclusivity and equality within the religion. Once second-wave feminism "burst forth and stormed American Judaism, change cascaded over the American Jewish landscape. Second-wave feminists sought to give power to one half of the people. In doing so, they gave American Jewish women the power to transform all of American Judaism" (Nadell 2009).

${ }^{14}$ See Blu Greenberg's On Women and Judaism: A View from Tradition (Greenberg 1981).
} 


\section{What is Feminism?}

Feminism can be generally defined as a movement searching for equal political, economic, and social rights of women. Feminism concerns itself with the inferior position of women within a society and the discrimination encountered by women because of their sex. Furthermore, Freedman argues that "[all] feminists called for changes in the social, economic, political, or cultural order, to reduce and eventually overcome this discrimination against women" (Freedman, 1). In order to reformulate questions and articulate different methodologies, feminist theorizing has attached itself to ideas of liberalism, Marxism, psychological theory, environmentalism, and post thinking of all sorts, accepting some of their foundational assumptions as well as producing new answers (Abbassi and Lutjens, 4).

The first women's movements in the United States and Britain in the $1840 \mathrm{~s}^{15}$ did not call themselves feminists. Feminism is a term that emerged long after women started to question their lower status. Furthermore, many women's rights organizations in the late 1960s and early 1970s deemed the term 'feminism' restrictive, because it could be interpreted as related only to specific concerns and specific groups (Freedman, 3). Therefore it is important to differentiate feminism and feminists from those who are just generally concerned with women's issues.

A historical time line of distinct feminist movements throughout time can be used to create some kind of classification. These different periods are defined as "waves" that were generated by historical events. The first wave began in the United States and Europe

\footnotetext{
${ }^{15}$ These first movements were basically searching for liberty, equality, and the right of suffrage.
} 
at the turn of the twentieth century and was a consequence of the abolitionist movement in the early to mid-1800s in the United states which "furthered the feminist cause there, providing some of the rhetoric and forums for public discussions of the role of women in society" (Scholz, 5). The main focus of the first wave was on the de jure or officially mandated inequalities, primarily concentrating on gaining women's right for suffrage. The second wave refers to feminist activity between the1960s and 1970s that was mainly spurred by civil rights activism. It focused on overturning official legal inequalities, de facto, and unofficial inequalities, such as those in the workplace, within the family, and women's own reproductive rights. The wave in the $1960 \mathrm{~s}-70$ s also sought to create solidarity among women in the experience of oppression, forming a kind of sisterhood ${ }^{16}$ among them. It was in this second wave that theoretical feminism defined the difference between gender and sex. The changes that occurred after the 1970s might be considered more drastic and are defined as third wave feminism, which recognized that women come from different ethnicities, races, nationalities, and religious background, and therefore tried to accommodate diversity and change. ${ }^{17}$ The last wave does not represent a single feminist idea but employs different theories and practices to challenge dominant ways of thinking and introduces new elements into personal and cultural consciousness (Scholz, 7).

\footnotetext{
${ }^{16}$ Sisterhood was argued to be a powerful political force to bring about change. Scholz remarks that later on, second wave feminism recognized the limitations of a common basis in experiencing oppression, because of differences between women, such as race and class that influence the way they perceive that oppression (Scholz, 7).

${ }^{17}$ The idea of a sisterhood among women is therefore rejected in this wave.
} 
Feminists were faced with the issue of theorizing differences intrinsic to women and dealing with the consequences of these differences in practice, and doing so was central to all different strands of feminist thought (Freedman, 7). Therefore, another way of classifying feminism is by schools of thought, in which different feminists attempt to define where sexual differences come from and the impact of those differences on the practical application of feminist ideas. I believe a basic understanding of the more widely-known schools of thought is important to my work, particularly the theories on motherhood that were articulated within some of the schools. I consider motherhood a very important trait of the rabinas and one that helps them to effectively perform their congregational duties.

In its beginnings, the feminist movement was influenced by socialism and Marxism, and the first two schools created within the movement were Liberal and Marxist feminism. With roots in social contract theory, Liberal feminism focuses on freedom for the individual, meaning that each person should be free in order to pursue her own version of good life. Feminists in this school believe that the oppression of women is built on their lack of legal rights and equal opportunities. Marxist feminism argues that oppression of women is a consequence of the material conditions of life rather than the legal barriers. It blames capitalism for the inequality of women in society.

Radical feminism draws on the idea of patriarchy ${ }^{18}$ as a way of controlling women's bodies and considers the roots of women's oppression to be sex-based, meaning

\footnotetext{
${ }^{18}$ I use the term patriarchy as defined by the Encyclopedia of Gender and Society as an "organization, institution, or society in which power, social control, material wealth, and high social status accrue predominantly to males rather than females" (Hill).
} 
it is grounded on biological roles, in reproduction, and in the place of women within a sex-divided society. Theorists of this school suggest a number of extreme solutions, ${ }^{19}$ provoking us to think in different ways about social interactions and gender (Scholz, 19). Socialist feminism attempts to blend the critique of patriarchy and capitalism. While some argue that capitalism and patriarchy are indistinguishable, others consider them two different systems that oppress women in different ways. This school proposes that ending patriarchy and capitalism is the only way to end women's oppression.

Cultural feminism focuses on gender and argues that the root of women's oppression is specifically in the feminine attributes that are devalued within any society. This school of thought provides some arguments that help build on my thesis. According to Scholz:

In most Western societies, caring or nurturing capacities are unappreciated, unacknowledged or excluded from politics and morality generally. This devaluation of caring oppresses women because women are traditionally the primary providers of care within families and society. To devalue care is to devalue women who do the caring. As one might guess, women are in something of a double-bind. The caring work they do is not adequately acknowledged or appreciated and yet society relies on it and often faults women who fail to fulfill it. Moreover, there is an extension of this critique to epistemology as well. Women's ways of knowing —often identified as intuitive or maternal—are excluded from those categories of knowledge claims that are considered valid sources (Scholz, 26).

Cultural feminism argues that failure to appreciate care and nurturing as central to human existence is a way of oppressing women. Indeed, "[m]any of the obstacles to women's

\footnotetext{
${ }^{19}$ For instance, one of the solutions they proposed in order to free women from the "tyranny of reproductive biology" is to use technological advances in order to replace biological reproduction. One example could be using artificial insemination and incubate infants in machines instead of the mother's womb. According to Radical Feminists, "abolishing biological reproduction would go a long way in abolishing the sex and gender roles in society" (Scholz, 20).
} 
participation in public and political life revolve around an assumption that women's compassion would get in the way of acting rationally" (Scholz, 28). But for cultural feminists rationality and compassion are not mutually exclusive, and liberation can only be achieved if men and women are free to care within any social context.

The last three schools of thought are womanist theory, postmodern feminism, and third world and postcolonial feminism. The first rejects the name 'feminism' proposing a re-examination of the term which recognizes that women's lives are affected by other social factors besides sex and gender, considering instead how these intersect with race and class. Postmodern feminism refuses to contemplate a single explanation for oppression and draws on a collection of ideas ${ }^{20}$ in order to understand where oppression comes from. Lastly, third world and postcolonial feminism traces the roots of oppression to the history of colonialism, exploitation, imperialism, sexism, and racism. Moreover, feminists within this school of thought are very critical of many dominant feminist ideas of the Western world, arguing that race is not adequately considered in these theories. Third world and postcolonial theories, on the other hand, place an emphasis on history, memory, and narrative.

A historical understanding of the movement is critical to a comparative analysis of its development in Latin America, where it had different implications and unfolded at a different pace. Even though Latin American feminism has been influenced by American and European feminist ideas, it has intrinsic particularities that make it a distinctive movement. In chapter three I will discuss the characteristics that give the

${ }^{20}$ See phallologocentrism, psychoanalysis, and sexual difference (Scholz). 
movement in Latin America its uniqueness. Understanding feminists' general ideas and historical process will also help guide the understanding of the development of the feminist movement within Judaism, and with it, the articulation of its main ideas and changes implemented within the Jewish mainstream. ${ }^{21}$ Within some schools of thought, the relevance of motherhood is extremely important, therefore I will provide important arguments for understanding motherhood, a key issue in my thesis because of its relevance in Latin America and traditional Judaism.

\section{Theories on Motherhood}

Women's biological ability to reproduce and bear children has been one of the key issues within feminist movements. Some see this capacity as the source of women's oppression; ${ }^{22}$ others embrace it as a key difference between men and women. Moreover, this difference influences a woman's social standing, sometimes becoming a burden on her, sometimes acting as an advantage to performing certain activities and professions outside their homes. According to Freedman, "Mothering is not only about biological reproduction but about a set of attitudes, skills, and values that accompany it, and some feminists argue that it is these attitudes, values, and skills which constitute the distinctness of femininity and which should be given a more central place in our societies" (Freedman, 21). It therefore becomes important to understand why women

${ }^{21}$ This issue will be developed in chapter two.

${ }^{22}$ See Betty Friedan's The Feminine Mystique (1963), Shulamit Firestone's The Dialectic of Sex (1970), Jessie Bernards' The Future of Motherhood (1974), and Mary Daly's Gyn/Ecology (1978). Defining reproduction as a site of oppression that ultimately see motherhood as a burden from which women have to free themselves was especially prevalent in the early years of secondwave feminism. Feminists believed that the only way to escape that oppression was by gaining control over their own bodies, and some advocated for birth control and reproductive technology as a way of gaining that control. 
mother. In her book, The Reproduction of Mothering (1978), Nancy Chodorow rejects the idea that mothering is an innate and natural instinct or a result of social conditioning, because that would imply that women who bear children had a choice in whether or not become mothers. She argues that gender identity is grounded in the children's identification with their primary caregiver. Thus girls become mothers and nurturers by emulating their own mothers, while boys learn, that in order to be males, they have to differentiate from their primary caregiver mother and become not-females (Kinser, 84). Thus for Chodorow, the desire to be a mother is associated with a desire to be feminine rather than with the biological function of women.

Adrienne Rich's book Of Woman Born (1976), distinguishes between the institution of motherhood and the experience of mothering. Rich tries to find a common ground between the radical feminist argument that motherhood is oppressive and incompatible with happiness, and the dominant culture's insistence of motherhood as the pinnacle of womanhood and femininity, without which is impossible to find happiness. Rich's work offered feminists an understanding of how motherhood could sometimes be oppressive but was not inherently so. What is oppressive is the institution of motherhood that is created by equating womanhood with motherhood. ${ }^{23}$ Furthermore, some even argue that if the oppressive structures of motherhood are dismantled, the experience of mothering could be "fulfilling and interesting" (Kinser, 85).

\footnotetext{
${ }^{23}$ Kinser defines this equation as: "The expectation that women should be economically dependent on men, the unequal distribution of household and social, and the limitations of women's access to gratifying work and education outside the home" (Kinser, 85).
} 
In her book, Maternal Thinking (1995), Sara Ruddick defines maternal thinking as a type of thinking a mother ${ }^{24}$ uses, in particular while engaging in the practices of protection, nurturance, and training. Mothering then becomes a discipline crafted by the interaction with children. Ruddick also argues that mothering is not grounded in a biological force, but rather in the intellectual and physical labor that characterizes the day-to-day practices of motherhood. Therefore mothering does not derive from a biological instinct, but is acquired through one's hard work, "discipline, focus, and persistent effort" (Kinser, 20-21).

Finally, Patrice DiQuinzio offers yet another perspective on essential motherhood, defining it as an ideology that "specifies the essential attributes of motherhood and articulates femininity in terms of motherhood so understood" (DiQuinzio, xii). According to DiQuinzio, mothering is a natural and biological function inevitable in women. The maternal function requires attention and care for children as well as psychological and emotional capacities for empathy, awareness of the needs of others, and self-sacrifice. Because these psychological and emotional capacities are natural in women, "[their] desires are oriented to mothering and [their] psychological development and emotional satisfaction require mothering." (DiQuinzio 1999, xiii). She also argues that essential motherhood represents women's sexuality in terms of mothering, so that the primary goal of women's sexuality is motherhood rather than pleasure. Essential motherhood therefore dictates that all women want to, and should be, mothers and that those who do not and are one, remain deviant or deficient as women (DiQuinzio, xiii).

\footnotetext{
${ }^{24}$ Ruddick is careful to remark that "mothers" are those fulfilling a particular role in childbearing, not only biological mothers, but biological fathers, caretakers, step parents, and adoptive parents among others.
} 
While there are different stances and theories on the issue of motherhood, what I want to highlight in this chapter is its centrality to women's roles, rights, and obligations. Knowing some of the arguments used to build on these theories is important to understanding motherhood as the traditional role of women within Latin America and Judaism. In my research, I stress the positive attributes of motherhood, not deeming them as undermining or as a means of oppression to women, because motherhood is what most distinguishes Latin American rabinas from rabinos. Thus, motherhood has a real influence on their as leaders of their congregations.

An understanding of feminism and its origins is crucial to my work, because the feminist ideas of the United States and Europe influenced women in Judaism and their search for equality. It is also important to know the history of its development, because it did not evolve at the same rate in Latin America, though it did function as a catalyst for the changes that would later bring equal rights to women in the region. I have chosen to focus on the school of thought that embrace motherhood, because of the significance of motherhood in the lives of Latin American women in general, and particularly in the rabinas' lives. Later in my research, this understanding of feminism will facilitate an analysis of how its ideas are linked (or not) to the actual lives, thoughts, and experiences of the rabinas. 


\section{Chapter II}

\section{Judaism: Jewish Denominations and Jewish Feminism}

"Every time I let myself be lulled into thinking that I as whole person am a member of this community, some event lets me know in no uncertain terms that I am wrong." Judith Plaskow (Shulman, 108).

Conservative Judaism is one of the main components of this thesis, and in order to better understand it, is important to first understand some basic concepts. This chapter begins with an explanation of the concept of Halakhah (Jewish law) because of its importance in Judaism and because its interpretation had a major impact on Conservative Judaism. New interpretations of the Halakhah have led to the progressive "equalization" of women within Judaism. I will also present the development of Judaism through different historical periods, including the general changes implemented in each period, as well as an overview of the role of women within the religion throughout time. Examining the historical role of women will enable the reader to understand the importance of tasks traditionally related to women, such as education, nurture, and care, and their impact on the lives of rabinas.

Present-day Jewish practices are a result of centuries of transformation within the faith; moreover, today, there are different denominations with diverse practices, beliefs, and halakhic interpretations. Until the mid-1800s, "Jews throughout the world were bound by a common dedication to the Halakhah despite ethnic differences in practices" (Ariel, 172). However, some people felt the need to adjust to modern times, and around 
1850, Reform Judaism was founded as an alternative to traditional Judaism. Orthodoxy was established as a response to this change and aimed to preserve those "traditional" ways. Between these denominations arose the Conservative movement, designed to strike a balance between old and new practices. This proliferation continued, producing Reconstruction ${ }^{25}$ as yet another alternative. It is important to understand the main differences between these movements in order to appreciate the impact of feminist ideas on each denomination, especially because their ideas led to the ordination of women rabbis. $^{26}$

The creation of the Jewish feminist movement was a process that started in the late 1800s. In her book, Women Who Would be Rabbis, Pamela Nadell tells the story of a Jewish communal activist, Mary M. Cohen, who in 1889 published a short story titled "A Problem for Purim,” on the front page of the Philadelphia's Jewish Exponent. In the story, the female protagonist raises the question, "Could not—our women—beministers?" (Nadell 1998, 2). The character presents different arguments to support the idea of women ministers; one of them was that women rabbis would not feminize the profession and make it unattractive to men. "Instead, [having women rabbis] promised to raise the quality and status of all rabbis by raising the excellence of the entire field" (Nadell 1998, 5). Many innovations had been, and were still being, introduced in American Judaism, thus Cohen prophesied that this "thing will be," it was just a question of when. By the mid-1900s, women had started to gain access to Jewish education;

\footnotetext{
${ }^{25}$ Reconstruction is another movement within Judaism whose ideas could be placed between those of the Conservative and Reform movements.

${ }^{26}$ In the Reform, Conservative, Reconstructionist and Modern Orthodox movements only, though the impact on each was different.
} 
egalitarian synagogues emerged, and women became more involved in leadership roles within their congregations. The ideas of Jewish feminists influenced women differently in each denomination, but were able to help them all find a "more equal" place. As previously noted, the question of women rabbis was raised at the end of the nineteenth century, but the answer was a long time coming.

\section{Understanding Judaism}

Defining Judaism and how it started is an extensive task well beyond the scope of this thesis. Though I am not providing much background information, there are aspects of Judaism which must be explored in order to understand the role of rabinas. It is usually anachronistic to refer to Judaism as the biblical religion of Israel, because there were no Jews (members of the tribe of Judah) in the formative period of the Bible. Furthermore, later Judaism is distinct from its earlier form in features, ideas, and worship. Judaism is based on three pillars: God, Torah, and the people of Israel. Different approaches to the Halakhah (Jewish law) lead to different ways of practicing Judaism, especially in the Conservative and Orthodox movements, and I will expand on this subject later. According to Judaism, God is a transcendent being who created and sustains the world, and gives its people free will. Torah is expressed in code and includes not only the text but its interpretations. Traditionally, it is said that the Torah she be al peh (oral Torah), a code of ethics and behaviors, was given to Moses along with the Torah she bikhtav (written Torah). What this dual Torah shares with the concept of Halakhah is an ongoing interpretation. By accepting the Torah, Israel became the "treasured people" of God, "a holy nation in the services of the Holy God," entering into a covenant that calls for 
obedience on their part and protective providence on the part of God (Katz, 138). In doing so, the people of Israel chose to obey and follow the Halakhah. The Torah, as the will of God, is immutable, and sages of rabbinic period used it as precedence for moral principles (Katz, 141-142).

Jewish history can be roughly divided in different periods. For the purposes of this thesis, I will follow Cohn-Sherbok's chronological timeline (Cohn-Sherbok, 9-11). The chronology I am offering is specific to tracking changes in women issues but the dates might slightly vary when delimiting the periods according to different authors.

The Biblical period (from c. 1900 B.C.E. to c. 450 B.C.E.) is characterized by Jewish sovereignty in the land of Israel. The picture of women in the Bible that emerges over this period is a mix of female vulnerability, oppression, rivalry, deceit, courage, loyalty and wit. Even though the Bible offers stories of exceptional women who enjoyed roles as prophetesses, judges, and military leaders, they are not central characters in the narrative. The biological function of women is central to female narratives in the bible; conception is a source of joy, while inability to conceive becomes piety and desperation. The Hebrew word isha in the Bible means both woman and wife, suggesting that a woman's identity was virtually inseparable from her status as a married woman. Carol Meyers believes it would be incorrect to assume that women were dominated by and made subordinate to men in all aspects of life, because the family functioned as a workforce, and with few resources outside the household, marriages were based on complement and interdependence. The primary care of young children was the mother's 
responsibility, and she was expected to train them in the duties of household life, teach appropriate behavior, and transmit cultural values (Meyers, 157-159).

The Rabbinic period (from around 450 B.C.E to the sixth century) is characterized by political elements and religious creativity. This period saw the codification of the Torah as well as the creation of other rabbinic scriptures. The Halakhah became very important during this period. Halakhah comes from the Hebrew word lalekhet (to go), and the rabbis of the Talmud explained that Moses was told by God to "make for the people the way they are to go (Exodus 18:20)" (Ariel, 161). According to Blu Greenberg, the Halakhah is a "way of living... that is as near perfect as a way of life possible" (Greenberg, 43). It is "near perfect" because it is a fluid and dynamic system that has to be perfected continually. Halakhah is considered to come from the Torah, but is actually a product of rabbinic Judaism, encompassing its comments and customs. The mitzvot (commandments) can be divided as mitzvot d'oraita (Aramaic for "from the Torah") or mitzvot d'rabbanan (Aramaic for "from the Rabbis"). A mitzvah deriving from a custom is called minhag. The mitzvot prescribe actions and behaviors for the Jewish way of life (Ariel, 159). There are 613 mitzvot, consisting of 365 prohibitions or "negative mitzvot" (things that one should not do) and 248 positive mitzvot (things one should do). The Talmud explains that the number 365 corresponds to the days of the year while the number 248 corresponds to parts of the human anatomy. This suggests that the mitzvot include every area of human behavior (i.e., 248) that occurs within time (i.e., 365) (Ariel, 163). The mitzvot can also be categorized as time-bound or not time-bound, depending on whether they have to be performed at a specific time or not. This constraint 
distinguishes what is obligatory for both men and women or for men only. Women are exempt from all time-bounding mitzvot (except in a few specific cases) ${ }^{27}$ because their daily schedules cannot be subjected to such limitations. Over time, different Halakhic approaches and interpretations (by sages and rabbis) led to alternative approaches to the law, and it was ultimately these different approaches that led to the differences between each Jewish denomination.

In this period, other scriptures were created, such as the Mishnah, six volumes of discussions and interpretations of the Bible by sages between 100 B.C.E and 220 C.E, and the Tosefta, composed of additional records that were not included in the Mishnah, which helped into de ongoing interpretation of the Halakhah.

The authors of the rabbinic period did not see Jewish women as equal to men, and they located the inequality in the narratives and injunctions of the Hebrew Bible ${ }^{28}$ (Ilan, 161). In Rabbinic literature, women are derogated as sources of "sexual temptation and menstrual impurity," classifying them as "subordinated and immature" (Raphael, 3352). Thus women become objectified and considered sources of sexual impurity. Rabbi Simeon Ben Shetah instituted the ketubbah, or marriage contract, during the Second Temple period (536 B.C.E. - 70 C.E.), which was considered a great innovation and provided women several legal rights in marriage that were binding in a written document

\footnotetext{
${ }^{27}$ Such as lighting the Shabbat candles and listening to the Megillah reading in Purim, among others.

${ }^{28}$ Mainly, women's subordination was understood as a consequence of Eve's role in Genesis 2:43 as a secondary creation. Moreover, contemporary concerns and Hellenistic influence merged with the biblical justification for women's subordination (Ilan, 161).
} 
including financial support for widows or divorcées ${ }^{29}$ (Ilan, 162-163). Rabbinic literature is not uniform; for example, while the Mishnah is more restrictive towards women, the Tosefta reveals a less rigid attitude towards them (Ilan, 165). The study of Torah was an important part of men's everyday lives; however, there are records of a woman named Beruriah, known to be very knowledgeable, as well as others. Society in rabbinic times was patriarchal and androcentric. Women were second in class and, generally dependent on a male relative (usually the father or the husband). Independent women (widows or divorcées) were seen as potentially disruptive and were encouraged to re-marry and "return to male control" (Ilan, 165).

The Medieval period (c.700-1700) was an extremely violent period during which the hopes of resettling in the land of Israel were shaded by expulsions and crusades. Jewish exile saw the need to exist and survive as a minority religion and culture in the different regions in which they had settled. The canonization of the Talmud, comprising selections from the Mishnah and the Gemarah (commentaries and discussions of rabbis), took place at the beginning of this period. The Medieval period is also characterized by Jewish diversity. The situation of Sephardic ${ }^{30}$ Jews was not the same as that of

\footnotetext{
${ }^{29}$ Nevertheless, Jewish feminists regard the ketubbah as a restrictive document for women. For example, in her book, Jews and Feminism: The Ambivalent Search for Home, Laura Levitt questions the historical claim that the ketubbah is made in order to protect women, and asks why women needed protection on the first place. She argues that "By naturalizing Jewish women's vulnerability as wives, the ketubbah both creates and justifies precisely this situation" (Levitt 1997, 43). She concludes that the text of the ketubbah reveals certain "Rabbinic preoccupations with control and authority as well as a series of fantasies about sex, violence, and pleasure and that wives are defined as utterly dependent (Levitt 1997, 48).

${ }^{30}$ Term applied to the Jews who fled Spain and Portugal after the expulsion of 1492 and went to other places of the world. Jews that come from the Arab world are also referred as Sephardim.
} 
Ashkenazi ${ }^{31}$ Jews; nor was the situation in Europe the same as in the Middle East, therefore it is hard to generalized the overall circumstances of women. Numerous letters from Genizah ${ }^{32}$ provide information about Jewish women living in the Arab world and also prove that there were women who were literate. ${ }^{33}$ In Medieval Ashkenazi societies women started to acquire more knowledge of the laws, and in some cases, rebelled against religious authority ${ }^{34}$ (Levine Melammed, 167). A few takkanot (rabbinic rulings) offering greater protection to women indicate they had a higher status than in periods before. ${ }^{35}$ In Medieval Christian Europe, many responsa ${ }^{36}$ show that legal authorities still relegated females to secondary positions. In addition, Jews were also influenced by their non-Jewish neighbors, assuming many of their social practices including views on what constituted appropriate female behavior. The position of women improved, and they

\footnotetext{
${ }^{31}$ In the Middle Ages, this term was applied to Jews living along the Rhine River in Northern France and Western Germany; then the core of Ashkenazi Jews moved to Poland and Lithuania, and finally spread all over the world.

${ }^{32}$ The period from 950 to 1250 is known as the classical Genizah period.

${ }^{33}$ Renée Levine Melammed writes in her essay, "Women in Medieval Jewish Society," about two groups of women: women living in medieval Mediterranean society known as the Genizah society, and crypto-Jews who were expelled from Spain in the $15^{\text {th }}$ and $16^{\text {th }}$ centuries. She notes the importance of communication between women and their families and friends during a period in history when women were largely illiterate. The importance of being able to find these writings and hear women's voices directly is extremely important (Levine Melammed, 93). She provides excerpts of letters that help the reader understand the life women lived back in those times.

${ }^{34}$ Known as the "Mikveh (place for a ritual bath) Rebellion," it happened when women (Egyptian Jews) in the $12^{\text {th }}$ century, discontinued bathing in the ritual bath because they wanted to wash their bodies under more pleasant conditions that the mikvaot (plural for mikveh) apparently afforded (Levine Melammed, 167).

${ }^{35}$ For example, a takkanah attributed to Rabbi Gershom Ben Judah in the eleventh century, forbade polygyny for Jews in Christian countries. Another example is a takkanah which states that no woman could be divorced against her will (Levine Melammed, 170).

${ }^{36}$ Responsa are written decisions and rulings of sages that expand the interpretation of the Halakhah.
} 
enjoyed a wide range of private and public roles including participation in the economy and religion. Jewish women played a vital and often "autonomous role in their family's economic life $[\ldots]$ allowing them to achieve almost unprecedented status and power in Jewish communal life" (Baskin 2007, 170). Women supplied part or most of the family income, allowing their husbands to study. This economic success empowered Jewish women in their domestic lives as well as in the communal and religious realm, as they engaged in commercial operations and occupations. Their domestic skills were also important, and included not only cooking, needlework, and housework management, but knowledge of the rules of rabbinic Judaism applicable to the home and marriage (Baskin 2007, 172).

Influenced by the Enlightenment as well as urbanization and secularization, the Modern period (1700 to present) is characterized by even more religious creativity. In general, there were two different trajectories within Judaism during this time: one strictly towards Halakhah (mostly recognized as the Orthodox movement), and the other towards adaptation to the modern times that defines what is nowadays known as the different denominations.

Within the Sephardic Diaspora there were powerful and empowered women who performed philanthropy and supported Jewish culture and learning ${ }^{37}$ (Baskin 2007, 174). The advent of the printing press in the fifteenth century gave women access to written material as well as the opportunity to publish tkhines (women's prayers), thus deepening the sense of religion and piety in the lives of Jewish women in Central and Eastern

\footnotetext{
${ }^{37}$ For example Benvenida Abravanel and Doña Gracia Nasi who continued the work of their deceased husbands, helping and protecting Jews in threatened communities (Baskin 2007, 174).
} 
Europe (Baskin 2007, 175-176). I will expand on this subject later on in this chapter. Women enjoyed a greater public presence, especially following the European Enlightenment, but they also needed to take care of their homes and families. It is also during this period that Jewish denominations were founded and the feminist movement emerged, both bringing about many changes in Judaism and in the lives of women.

\section{Understanding Jewish Denominations}

\section{The Reform Movement}

The Reform movement came as a historical response to the dramatic events of the eighteenth and nineteenth centuries in Europe ${ }^{38}$ From a religious point of view, "many Jews felt a tension between Jewish tradition and the way they were now leading their lives" (Kaplan, 165). Many responded to this situation by having even less regard for tradition, while others tried to reconcile their religious heritage with their surroundings by reforming it. By the early 1840 s a trained Reform rabbinic leadership emerged in Central Europe. Reform Judaism does not hold that either the written law (Torah) or the oral law (Talmud) were direct revelations from God to Moses. It accepts biblical and other historical criticism as legitimate, "understanding Scripture and tradition as a human reflection of revelation rather than its literal embodiment" (Meyer, 7665). Reform Judaism does not believe that the Halakhah is binding, and emphasizes the ethical purpose of Judaism over ritual practices. Rabbi Isaac Mayer Wise is considered the father of the Reform movement in the United States, the founder and driving force of the three major institutions of Reform movement: The Union of American Hebrew College

\footnotetext{
${ }^{38}$ Such as the increasing political centralization of the late eighteenth and early nineteenth centuries and the Enlightenment (Kaplan, 165).
} 
(UAHC, later the Union for Reform Judaism, URJ), founded in 1873, Hebrew Union College (HUC) founded in 1875, and the Central Conference of American Rabbis (CCAR) founded in 1889 (Kaplan, 167). After World War II, religious practices for the most part became more traditional as Jewish law was understood not as authoritative but as a way of life. Religious services incorporated more Hebrew (rather than reading the English translations) and ritual practices became as important as social action. Nonetheless, Reform Judaism is still radically different from Conservative and Orthodoxy in some issues ${ }^{39}$ (Meyer, 7672-7673). Regina Jonas, a German woman, was ordained as Reform rabbi in Germany in 1935. In the United States, the movement ordained the first woman, Sally Priesand, in 1972, and is nowadays considered egalitarian.

\section{The Orthodox Movement}

Orthodox Judaism (from the Greek orth, "correct" and doxa "believe") is the branch of Judaism that most strictly adheres to the Halakhah. The Orthodox movement sees itself as the authentic carrier of Jewish tradition since ancient times (Zohar, 462). It first developed in Germany and Hungary in response to the "changes which occurred in Western and Central Europe in the first half of the nineteenth century: Reform [Judaism], the Haskalah (Jewish Enlightenment), and trends toward secularization" (Katzburg, 493). Orthodoxy maintains that the Torah was revealed to Moses on Mount Sinai, directly from

\footnotetext{
${ }^{39}$ According to Orthodox Halakhah, a child born to a Jewish mother is considered a Jewish child. Reform Judaism, for example, made an incredible change by implementing the recognition and acceptance of children from mixed religious parentage (whose father is Jewish but mother is not, say) as Jewish. According to the Reform movement, this measurement not only gives equality in religious leadership to gays and lesbians but also seeks to make non-Jews married to Jews feel welcome in the synagogue (Meyer, 7673).
} 
God, that the Halakhah derives "directly or indirectly from an act of revelation," and that Jews have to live according to the Halakhah "as interpreted by rabbinic authority" (Liebman 2005, 6898). Orthodoxy has expanded all over the world, and its most important centers are in Israel and the United States. The movement can be divided into two major groups: the "ultra-orthodox" or Haredi (awestruck), and Modern or NeoOrthodox. The Haredim (plural of Haredi) usually live isolated from the secular world, in groups in which men are devoted to studying Torah while women are mainly in charge of the care of their homes and children. Modern Orthodox people work and participate in the secular world but live a strictly religious life. For the purpose of this thesis, whenever I use the term Orthodox, I am referring to Modern Orthodoxy since it is currently being influenced by Jewish feminists' ideas and is thus closest to the topic of my thesis. The Orthodox rabbis who interpret laws believe that the "Torah does not have to be afraid of modernity since there is no challenge that the Torah cannot cope with" (Rackman, 497). Some Orthodox organizations are the Rabbinical Council of America (founded in 1923) and the Union of Orthodox Hebrew Congregations (founded in 1926).

Women's roles in orthodoxy have been defined as "equal but different" (Raphael, 3353), and they are excluded from active participation in public ritual. Women are by custom, not law, in charge of nurturing a sense of Jewishness in children and infusing their homes with a Jewish atmosphere. Men and women's religious practices are considered complementary. Furthermore, Orthodoxy considers women to be on a higher spiritual plane than men, therefore orthodox women do not need a fixed schedule to pray and connect with God (Raphael, 3353). This is another issue I will expand on later in this 
chapter. Most recently, the controversial Orthodox Rabbi Avi Weiss from Riverdale, New York, ordained the first orthodox woman rabbi, Sara Hurwitz, in February 2010. The majority of the Orthodox world does not recognize her as a rabbi, since this is its first and only case. Nevertheless, I believe that in the future, Orthodoxy will be faced with these issues more frequently as Orthodox feminists are slowly trying to expand their rights.

\section{The Conservative Movement}

The Conservative movement sought a balance between tradition and modernization, understanding that times change but that in adapting to those changes, people need to also preserve Jewish tradition. The Conservative movement is considered to have evolved from the ideology of German Rabbi, Zacharias Frenkel. In 1845, he broke with his more radical colleagues at the Rabbinical Conference of Frankfurt (Reform) over the issue of retaining Hebrew as the language of prayer. In 1854, he founded the JüdischTheologisches Seminar of Breslau as a way to concretize his conservative yet flexible approach to Judaism (Golinkin and Panitz, 171). In 1885, the radical Reform wing passed its Pittsburg Platform, dismissing biblical and rabbinical rituals regulating diet and dress as anachronisms. As a response, moderate rabbis and scholars called for the establishment of a new rabbinical seminary "more hospitable to traditional Judaism" (Golinkin and Panitz, 172). By January 1887, the Jewish Theological Seminary (JTS) was established in New York City for those Jews who would both "uphold Mosaic law and adhere to a historical Judaism resting upon the great interpretations of rabbinic literature codified in works like the Talmud" (P. Nadell 2005, 1958). 
The JTS graduated fourteen Conservative rabbis and three cantors between 1894 and 1902, and in 1901 the graduates founded an alumni association which grew into what is known today as the Rabbinical Assembly. Solomon Schechter became the JTS's president in 1902, and under his leadership the seminary fulfilled its mission "among American Jewry by producing religiously observant and intellectually open-minded rabbis" (Golinkin and Panitz, 172). In 1913, twenty-two congregations joined to form the United Synagogue of America, which embraced Schechter's vision, welcoming congregations that were not avowedly Reform and promising moderate reforms to Judaism. In 1918 Solomon Shechter's widow, Mathilde Schechter, founded the National Women's League of the United Synagogue of America, the umbrella for the "sisterhoods that flourished as gendered spaces in these new synagogues" (P. Nadell 2005, 1959). After World War II, Conservative Rabbis were faced with the fact that the processes of modernization, secularization, and Americanization had affected Jewish attachment to Halakhah. Since they understood the Halakhah must govern Jewish life, they believed they needed to reshape it in order to find a proper balance between tradition and change. In 1947 the JTS established its West Coast branch, the University of Judaism in Los Angeles, and in 1957 the World Council of Synagogues was established to extend the Conservative vision to the world. The Seminario Rabinico Latinoamericano in Buenos Aires, Argentina opened its doors in 1962, and in 2003 the Masorti (traditional) movement was established in Israel. Nowadays, Conservative Synagogues are considered egalitarian, and women participate in rituals and the synagogue alongside men. In 1985, Amy Eilberg was the first woman in the movement to become ordained as rabbi. Because of the already struggle within the movement on how to balance modernization and 
tradition, rabbis were uncertain to what extent the ordination of women would have a positive impact within the movement. Hence the debate was much more extensive than it had been within the Reform and Reconstructionist movements.

\section{The Reconstructionist Movement}

The Reconstructionist movement originated in the philosophy of Mordecai Kaplan (18811983) in mid-1900s America, as a way to make Judaism meet the needs of children of Eastern European immigrants who had arrived in the early twentieth century and of those born later in the United States. Kaplan, a rabbi with Conservative training, wanted to create a "blueprint for a new way of being Jewish," combining the best features of traditional Judaism with the American way of life. Choosing the term Reconstruct, indicating both respect for tradition and an awareness of the need to remodel it to fit American life, he saw his plan as a contrast to Reform Judaism (which according to him lacked a connection to Jewish traditional practices) and rejected the idea that Judaism needed to be conserved without change (Alpert, 7635). In 1968, the Reconstructionist Rabbinical College (RRC) was founded. The movement now includes Hasidic, Kabbalistic, meditative practices, and teachings broadening the spectrum of spirituality. The movement also had to "grapple with creating positions and practices that if not exactly couched as a return to Halakhah, meant a serious engagement with Halakhah" (Hirsch, 148). Reconstruction ordained the first woman rabbi, Sandy Eissenberg Sasso, in 1974, and these days is considered egalitarian.

After understanding the basics of Judaism and how different denominations emerged as a response to specific needs of people in different times, I will now introduce 
Jewish feminism. Jewish feminists identified with different denominations were able to bring up the question of equality within each movement as well as facilitate change.

\section{Jewish Feminism}

It is hard to clearly define the beginnings of the Jewish Feminist movement. Some argue that the push for the emancipation of women in Western Europe by the Haskalah (Jewish Enlightenment) had a religious impact on the emancipation of women in liberal Jewish communities ${ }^{40}$ sharing its complexities and contradictions (Raphael, 3354; H. Safrai 1992, 59; Prell, 5). In the United States, second wave feminism gave women greater access to Jewish education; as a consequence, women became more knowledgeable in issues of Judaism, and new voices emerged in Jewish scholarship and theology. Once American Jewish feminists turned their attention towards Judaic cultural heritage and contemporary Jewish societies and institutions, big changes started to occur. Even so, Jewish feminists are not a monolithic group, and have several different areas of primary interests. ${ }^{41}$ For many, the greatest impact of Jewish feminism was epitomized by the

\footnotetext{
${ }^{40}$ Freidenreich illustrates this in her essay, "How Central European Jewish Women Confronted Modernity," where she tells us how, with the introduction of the Haskalah movement in the late $18^{\text {th }}$ century, Jewish women in Germany, especially the wealthy, started to distance themselves from the traditional role of women as wives and mothers, gained more acceptance in German intellectual and social circles, and came to be known as "salon women" by the early $19^{\text {th }}$ century (Freidenreich, 133).

${ }^{41}$ Sylvia Barack Fishman highlights some examples in her essay, "Women's Transformations of Contemporary Jewish life," which included but were not limited to (1) marking women's lifecycle events with Jewish sacralizing and/or ceremonies and rituals; (2) Including women in worship as leaders and active participants; (3) upgrading Jewish education of girls and women; (4) promoting Judaic scholarship by Jewish women and about Jewish females in classical texts and throughout history; (5) creating gender-inclusive liturgy; (6) reclaiming and publishing materials about women experiences historically and today; (7) examining religious texts, laws, and customs through lenses of feminist theory and equality; (8) creating religious and secular legislations to end religious mandated unequal power in relationships; (9) creating inclusive Jewish attitudes and environments for Jews living in non-traditional households; (10)
} 
appointment of women to religious leadership roles that culminated with the ordination of women rabbis in the Reform, Reconstructionist, and Conservative movements. In order to understand the basic claims of Jewish feminists and how their ideas influenced the change in the status of women within Judaism, I will be focusing on the American Jewish feminist movement. I do so because I believe that it was American Jewish feminism that had the greatest impact on Conservative Jewish Latin America for two reasons: First, the Conservative movement was introduced in the region through American influence, importing its beliefs, practices, and ideas. Second, the ideas of American Jewish feminists had the greatest influence in bringing equality to women within Conservative Judaism and pushing for the ordination of women as rabbis. Therefore I consider that the ordination of Latin American Conservative rabinas is a consequence of the impact the American Jewish feminist movement had on the leadership of the Conservative movement in the United States.

\section{Understanding the Basics of Jewish Feminist Thought}

As with the feminist movement in general, Jewish Feminism encompasses many different points of views. Orthodox feminism shares the same important assumption with feminists from other denominations: Judaism is not gender-equal. One can generally define Jewish feminism as a movement which seeks the right for Jewish women to participate fully in Judaism and Jewish life, something denied to them prior to the last century. The idea of equality is emphasized within the movement, therefore "Jewish feminism challenges the assumptions on which Judaism is based, including that gender is a key principal in

incorporating women's theological and philosophical challenges into a predominantly patriarchal religious culture (Fishman, 186). 
determining Jewish rights and obligations" (Prell, 5). Jewish feminists claim that since men were historically the normative religious authority, women became secondary in status. Some feminist scholars argue that this turns women into the Other, because men are always the definers and women always the defined (Plaskow 1989, 2). Post-biblical texts were aimed at men, written and influenced by the male perspective (H. Safrai, 61), and Jewish feminists claim that therefore the Halakhah regards women as second-class citizens. According to Rabbinic Judaism, a woman's role is centered on the marital home (Raphael, 3352). This argument is clear in that many of women's mitzvot (commandments) revolve around the house and its chores. ${ }^{42}$ Others argue that these laws are designed to protect women because of their perceived "vulnerability".

Influenced by second wave feminist thought, by the end of the 1960s, Jewish feminism had made a great impact on the leadership, practices, organizations, and beliefs of Judaism, remaining a "broad cultural umbrella under which to gather the ideas, institutional and communal structures, aesthetics, political activism, ritual and liturgical innovations, theologies, and new sacred objects associated with it" (Prell, 1). Jewish feminism challenges the patriarchal nature of Judaism and demands recognition of women as full persons rather than defining them only in relation to men (Shulman, 109). Influencing all denominations of Judaism, the movement was able to push for the inclusion and equality of women. Still, the changes impacted women differently in each denomination and were (and still are) ${ }^{43}$ implemented with certain controversy and

\footnotetext{
${ }^{42}$ Such as lighting Shabbat candles, baking the Challah, and keeping a Kosher home, among others.

${ }^{43}$ In the case of Orthodoxy.
} 
reluctance from male leadership. Some of the areas affected by Jewish feminism were theology, Halakhic interpretations, the synagogue, and rituals. I will provide some examples of the exact changes and how they were implemented.

\section{Jewish Feminist Theology}

Jewish feminist theologians seek to bridge the patriarchal nature of Judaism by redefining the classically male-authored Jewish understanding of God and concepts associated with God such as revelation, the problem of evil, and the nature of prayer (Heschel 2007, 755). Recognized feminist theologians from different denominations such as Judith Plaskow, Rachel Adler, Marcia Falk, and Tamar Ross, share the task of finding new ways of defining women and women's experiences in Jewish tradition. As Ross states in her book, The Women's Question in Judaism, this task is a difficult ideological enterprise of major proportions (Millen, 27) and different methodologies have to be used to develop a feminist theology. For example, Plaskow uses Elisabeth Schüssler Fiorenza's "hermeneutics of suspicion ${ }^{44,}$ and "hermeneutics of remembrance ${ }^{45,}$ to reconstruct the fundamental conceptual assumptions of Jewish thought. In her book, Standing Again at Sinai, Plaskow argues that in the areas of Torah, Israel, and God “women's history, experience, and perspective have been put aside and do not determine the forms articulated by and practiced within the tradition" (Millen, 30). She analyzes

\footnotetext{
${ }^{44}$ According to Schüssler Fiorenza, a hermeneutics of suspicion "scrutinizes both the presuppositions and the interests of interpreters, and that of biblical commentators as well as the androcentric strategies of the biblical text itself." One should regard the text suspiciously in order to "identify the ideological functions of kyriocentric text and commentary" (Schüssler Fiorenza, 223-224)

${ }^{45}$ Hermeneutics of remembrance attempts "to recover [women's] religious history and the memory of their victimization, struggle, and accomplishments and [women's] heritage," seeking for an historical retrieval and religious constitution of the world (Schüssler Fiorenza, 224).
} 
how Judaism would be if women's voices and experiences would have been used in creating Jewish law and customs, their vision of Divinity, and the story of the Jewish people. Rachel Adler also proposes a different theology, one for engendering Judaism in two senses: "a way of thinking about and practicing Judaism that both, men and women recreate and renew together as equal" (Adler 1998, xiv). Feminist theology leads to changes in interpretations of the Halakhah, liturgy, rituals, and prayers, and some have been taking place already.

In the area of Biblical studies, many scholars focus their analyses on the treatment of women in the Bible, trying to understand it, and also searching for alternative interpretations; this research is vital to understanding the role of women in the Bible. ${ }^{46} \mathrm{In}$ the area of post-Biblical studies, women are almost uniformly absent from stories in Rabbinic literature; furthermore, there is no discussion of women studying Torah despite the fact that many exceptional women were probably learned in Torah. ${ }^{47}$ Gender has then become an acceptable tool when exploring rabbinic texts. ${ }^{48}$

\footnotetext{
${ }^{46}$ In her essay, "Jewish Feminist Approaches to the Bible," Esther Fuchs remarks that feminist biblical scholarship is interested in the literary, historical, ideological, and philosophical configurations of women (Fuchs, 25). She also explains the importance of feminist Midrash that seeks to "Provide intention, motivation, psychological depth, and political relevance to female characters" for biblical interpretation (Fuchs, 32).

${ }^{47}$ For example, Beruriah, who I have previously mentioned.

${ }^{48}$ Dvora Weisberg, for example, explores this issue in her essay, "Women and Torah Study in the Aggadah." She writes that recently there have been developed explorations of the feminine in Aggadah in a critical, scholarly context. The fact that Judaism has androcentric texts is known and cannot be changed; nevertheless, Weisberg believes that although feminist scholarship "Will not correct that," newly generated Aggadah with the study of Halakhah still has much to add to the understanding of the feminine in Judaism (Weisberg 2009, 59).
} 


\section{The Halakhah from a Feminist Perspective}

I believe Halakhah is part of an ongoing tradition that needs to change and adjust with the times. Grossman and Haut also believe that today "all branches of Judaism are grappling with the tension between contemporary values and traditional observance, the acceptance of the ideals of equality and the tradition of role differentiation" (Grossman and Haut 1992, 85). The distinctions made in the Halakhah between women's and men's obligations have had a major impact on women's lives and the way they function within society. Jewish feminists believe that some of the issues covered in the Halakhah have to be re-interpreted because they restrict women. Blu Greenberg, an Orthodox feminist, puts it this way: "In some very real ways, halakhic parameters inhibit women's growth, both as Jews and human beings" (Greenberg, 40).

Hana Safrai explains the importance of treating all human beings as equal. In her essay, "Traditional Judaism and the Feminist Challenge," she writes:

Exclusion of women is a sin in light of 'Thou shalt love thy neighbor as thyself.' The feminist challenge contends that this principle should be applied to all human beings, men and women alike. We should transform the world of Halakhah, the world of Jewish society, the world of Worship God, into a place where all 'as thyself' and all part of the divine identity of love. If man was created in the image of God (Gen. 9:6), and the divine essence is defined in Judaism by the choice of the verse "Thou shalt love', and by the comparison between love for man (Lev. 19:18) and love for God (Deut. 6:5) then this identity between man and God extends to the feminist challenge. It compels bringing religious women to the place of Blessed-be-He, and requires their inclusion in the Halakhah and court decisions on social and family matters (H. Safrai 2007, 70).

While there is no general consensus among Jewish feminists on the extent to which the Halakhah should change, the general idea that the status of women in certain areas of 
Jewish law requires redefining is shared by all. In the last century, different halakhic interpretations were formulated, leading to changes for women in Judaism. From mixedseating in the synagogue (except in the Orthodox movement), to active participation of women in prayers, Torah reading, liturgy, rituals, and customs, these changes were a great step toward the equalization of women's role in Judaism.

\section{Women and the Synagogue}

The synagogue plays many roles in Judaism—a house for praying, studying, and gathering. Synagogues started to appear after the destruction of the first Temple by the Babylonians in 586 B.C.E; however, the sanctity of the Temple was always greater. After the destruction of the second Temple by the Romans in 70 C.E., many of the features and functions of the Temple were transferred to the synagogues. One of the features is the mehitza, or division between men and women. This division might have stemmed from what was known in the second Temple as Ezrat Nashim, or the Women's Court, which is mentioned both in the Mishnah and Josephus. Ancient writings prove that women were active in both of the Temples, attending the festivals and offering sacrifices alongside men (Grossman), and Grossman argues that the idea of the women's court serving to segregate female from male worshipers is a popular misconception (Grossman 1992, 22). The women's court stood to the east of the inner court and was not intended to separate men from women for religious reasons but for moral ones, as it was specifically used for the ceremony of water libation on the first evening of Succot (the feast of the Booths or 
tabernacles), referred to as Simhat Neti ha-Sho'evah. ${ }^{49}$ The gallery was probably the model for the women's gallery in the synagogues as we know them today, and historical records show that by the thirteenth century, this custom was widespread (Kolatch, 140).

After the establishment of synagogues, women were still involved and participating in different ways in a range of activities within the synagogue. ${ }^{50}$ For example, in the Middle Ages women in the Islamic world attended synagogues in order to pray, socialize, and obtain judgment. Depending of their social class, they were involved as caretaker or made monetary offerings, but unlike men, they could not fill official communal roles as a result of their offerings (Reguer, 55). Towards the later Middle Ages, women's galleries or rooms, women's prayers, and women prayer leaders became more common (Taitz, 65), but the synagogue was still mostly dominated by men. Women were not considered in prayers and did not count as part of minyan (minimum quorum of ten required for certain prayers). Nevertheless, some women still practiced their spirituality in the form of Tkhines ${ }^{51}$ and gathered together in prayer groups.

\footnotetext{
${ }^{49}$ Grossman suggests that women were separated to "ensure that the celebration, similar to pagan festivals in so many ways, did not degenerate into what was seen as one of the most loathsome of pagan practices - sexual liaisons during, and as part of, ritual activities." She concludes that this must have been enough in the rabbinic imagination (following the reasoning above based on Tosafot), to segregate women during that festivity (Grossman 1992, 24).

${ }^{50}$ Sources such as Paul in the Book of Acts, Philo of Alexander in his "On the Contemplative Life", and in rabbinic Halakhic discussions already mention women being present and participating in synagogues (H. Safrai 1992, 39-40).

${ }^{51}$ Chava Weissler touches on the Tkhines which are writings from women that were produced for a wide variety of occasions and structured women's spirituality lives (Weissler, 117). In them they could resonate not only the communal events of the Jewish calendar, but also "The private events of the women's domestic life" (Weissler, 118). Trough the Tkhines women showed that they also have spirituality and can live a religious life as well. They also presented an opportunity for them to participate in Kabbalah and Jewish mysticism, something that as women were not
} 
Although the synagogue has traditionally been defined almost exclusively by male dominance and female marginality, Karla Goldman asserts that for "acculturated nineteenth-century American Jews, the synagogue actually became an important and dynamic site for the expression of female religiosity" (Goldman, 57). The importance of the synagogue happened not only in the United States, but in Europe as well, where people started to realize that some of the practices of the synagogue were not suited for the modern age. In American Judaism, physical changes were made to the synagogue in order to display greater respect towards women (Goldman, 58). By 1955, the practice of mixed-seating was widely observed in Reform synagogues in Europe, the United States, and by an "overwhelming majority of Conservative congregations and served as a yardstick to differentiate them from their Orthodox counterparts" (Rubin Schwartz, 156). Furthermore, by the end of the nineteenth century, women's attendance at the weekly Shabbat services was greater than that of men (Goldman, 59). Mixed-seating was the first change to the traditionally known structure of the synagogue, and it subsequently prompted other changes. Many re- interpretations of the Halakhah led to the inclusion of women in prayers, allowed women to bless and read the Torah, changed the male language of certain prayers, included women in rituals and ceremonies, and even produced new rituals and ceremonies exclusive to women.

\section{Women, Prayers, and Ceremonies}

Rachel Adler tells us in her book, Engendering Judaism: an Inclusive Theology of Ethics, that real inclusion of women in the synagogue can occur "only when women cease to be able to do. Examples of some of them can be found in "Tehines: A Brief Survey of Women's Prayers" (Berger). 
invisible as women" (Adler, 63). The absence of women's voices in prayers and in the synagogue makes them invisible. There is a distinction, according to Jewish Law, between men's and women's obligation in formal prayer as part of a larger distinction, which is women's obligation to perform mitzvot (Haut, 90). As mentioned earlier, women are exempt from performing time-bound positive commandments. ${ }^{52}$ Since prayer is a positive commandment but is not easily categorized as being time-bound or independent of time, there is no consensus by rabbinic authorities on women's obligation to pray in public.

In regards to the minyan, the Mishnah establishes the need for a leader and determines who is or is not eligible. ${ }^{53}$ The Halakhah states that women cannot count as minyan; however there is no generally agreed-upon explanation for why. Some rabbis did not want to burden women "to have to attend to their Creator at regular and specific times because that might interfere with their husbands' needs" (R. Haut, 137). Others felt that women's activities should be limited to the home as much as possible. So it was concluded that since women are not obligated to pray in the synagogue, they cannot lead prayer, because they cannot perform the obligation for those who are. Furthermore, some rabbis argue that women cannot lead because of the prohibition of Kol Ishah, which

\footnotetext{
${ }^{52}$ Except those such as eating matzah, drinking the four cups of wine during the Seder, and hearing the Megillah in Purim, because the Torah specifically mentions they are obligatory (Haut, 91).

${ }^{53}$ For example, it says that a child may not lead the Shema, or the fixed prayer, or the priestly blessing, or read from the Torah and translate, and a person covered with a rug whose limbs are exposed, may lead the Shema but not read from the Torah (Hauptman 1992, 161). Social modesty, Hauptman concludes, seems to play a role in the performance of religious rituals, not gender.
} 
states that one cannot listen to a woman's voice for this might lead to sexual arousal (R. Haut, 137).

When it comes to reading from the Torah, traditionally women were not called because, in ancient times, they were not sufficiently educated to read their own portions. The same was true for uneducated men. However, even if there was a woman who knew how to read the portion, she would not be allowed to read it either. This prohibition stems from 'kavod ha-tzibur,' the belief that if a woman is called upon to read from the Torah it means that the congregation does not have any man who knows how to do it, and might therefore be embarrassed (R. Haut, 138).

All these issues disturbed the Reform, Conservative, and Reconstructionist Judaism. Hauptman writes that "a Conservative Jew understands that there is a level of subjectivity in rendering halakhic decisions, that there is more than one way to interpret a source and what predisposes a decisor to rule in a particular manner is his own set of ethical sensitivities and his perception of the socio-religious realities of his day" (Hauptman 1992, 170-171). Therefore the Conservative movement has issued a number of responsa addressing specific requests by women for greater equality-within the framework of the Halakhah—in the synagogue and liturgy.

Aaron H. Blumenthal proposed a responsum implemented by the Conservative Committee on Jewish Law and Standards in 1955, allowing women to be called upon for aliyot (plural for aliyah). Blumenthal said, "the time has come for someone to reverse the direction in which the Halakhah has been moving for centuries" (Rubin Schwartz, 158). However, as late as 1972, only seven percent of 142 rabbis regularly gave women aliyot, 
another seventeen percent granted them only on special occasions (Nadell 2009, 159). In 1973 the committee passed another resolution allowing women to count equally with men in the minyan. Its author remarked that one could not ignore how the world was radically changing, the status of women along with it, and that these changes needed to be reflected in religion as well (Rubin Schwartz, 159). Additional resolutions later expanded women's role in other areas of ritual including serving as prayer leaders. Nevertheless, these changes took some adjusting to for Conservative Jews. From 1972 to 1976 the number of Conservative congregations in the United States giving aliyot to women increased from seven to fifty percent, and by 1986 eighty-three percent of congregations counted women in the minyan (Rubin Schwartz, 159).

Once women had achieved equal inclusion in the synagogue, they were faced with another issue: the male language of prayers. Hebrew language does not permit the use of a neutral third person, because it is a language in which each word is gendered. Nonetheless, it is possible at least intellectually to conceive God as neutral even if the language is masculine. For some feminists, the fact that God is referred to as "He," and through male metaphors, present an additional problem, especially in English translations. Some feminists argue that they cannot identify with a male God. ${ }^{54}$ Furthermore, feminist theologians believe that referring to God with exclusive male language is idolatrous (Adler, 85). There are many different ways in which Jewish feminists are addressing these issues. First, they are faced with making an inclusive

\footnotetext{
${ }^{54}$ As for example Rabbi Lynn Gottlieb who dedicated a whole book to the creation of a more female God by association It with the Shekhinah, the female presence of God in the Kabbalah (Gottlieb).
} 
prayer book. Adler asserts that if "women and men made prayer books together, we would affirm that our maleness or femaleness is a vital component of the self we bring to worship. At the same time, we would be constantly reminded that attributing gender to God is metaphoric and not literal" (Adler 1998, 66).

The Reform, Conservative, and Reconstruct movements changed their prayer books in order to make them more "gender-inclusive." ${ }^{55}$ Some Conservative prayer books have also changed the Hebrew to include the female gender so that women, as well as men, can pray in the appropriate language (Daum, 191). As a way of addressing the male imagery of God, Sim Shalom, a Conservative prayer book, offered some supplementary readings in which God is portrayed as a Mother who comforts Her Children (Daum, 193). I believe that moving to the opposite extreme and describing God only with feminine attributes is equally misguided. People are still searching for a gender-neutral way of referring to God that honors and includes both sexes; because of its complexities, consensus between men and women on this issue is probably still a long way off.

Another way women became included in synagogue practices, was their newfound ability to preside over ceremonies that were traditionally performed for and by men. The bat mitzvah (coming to age) ceremony was first introduced by Rabbi Mordecai

\footnotetext{
${ }^{55}$ For example, there is a prayer still recited every morning by Orthodox males: "Blessed art Thou, Lord our God, King of the Universe, Who has not made me a woman." This is an example of a prayer created under male dominance. Even though it is explained that this prayer is as men's gratitude to God for having the privilege of performing all mitzvoth, Jewish feminists note how it implies the inferior status of women. Conservative Judaism offered a possible solution to the dilemma by changing the language to thank God for "making me an Israelite" which could be recited by both men and women (Daum, 189-190).
} 
Kaplan in 1922. Since then the ceremony has been widely performed in the Reform, Reconstructionist, and Conservative movements. However, in the early years of that practice within the Conservative movement, girls would only go to the Torah on the day of their bat mitzvah, after which they were not allowed to go to the Torah again. Nowadays, girls enjoy fully participation in their bat mitzvah Friday night as well as Saturday morning services and reading from the Torah. ${ }^{56}$

Maintaining their commitment to Orthodoxy, some women have created viable prayer groups to draw nearer to experiential communal prayer (R. Haut, 140). Orthodox women get together, sometimes for Rosh Chodesh and mostly for Shabbat mornings, to conduct full services (except for prayers that require a minyan) and read from the Torah and Haftarah. ${ }^{57}$ These groups are an opportunity for women to thank God, and they celebrate B'not (plural) mitzvah (in which girls read from the Torah and Haftarah), engagements, and baby namings. Another innovation is that women are called to the Torah by the names of their mothers as well as their fathers. The groups are also encouraging the creation and development of women's Torah interpretations (R. Haut, 143). These prayer groups do not have total acceptance by male rabbinic leadership, nonetheless, some Orthodox rabbis have been quietly encouraging (R. Haut, 148).

\footnotetext{
${ }^{56}$ Furthermore, some Orthodox congregations perform the ceremony in the women's section.

${ }^{57}$ According to the Halakhah, since men are not present, women are allowed to lead prayers and receive Torah honors (R. Haut, 135).
} 
During the past twenty years, feminists Jews have invented religious ceremonies and language, many of them commemorating life-cycle events. ${ }^{58}$ These developments articulate the possibility for holiness in women's experiences and concerns because "they provide opportunities for Jewish women to mirror for one another what Jewish women could be" (Adler, 69).

Over time, all these distinct changes that took place collectively led to the ordination of women rabbis. However, it is important to note that the first shifts in the status of women within Judaism were largely conceived and implemented by men, especially rabbis (Nadell 2009, 162). What stands out here is the gender of the actors; at first, they were men, but after the ordination of the first woman rabbi, the actors in the debate over Jewish women's religious roles were women themselves. As Rabbi Priesand, the first woman ordained within the Reform movement in the United States in 1972 said, her appearance in a forum series became a lesson in consciousness-raising, giving women "the courage they need to demand complete participation in synagogue life." Two years after her ordination, women were moving into positions in Jewish congregations and synagogue boards; even liturgy committees began the process of challenging the androcentric language of prayers (Nadell 2009, 163). The ordination of women rabbis was the last major step required to show that Judaism was on its way to being egalitarian.

\footnotetext{
${ }^{58}$ Adler mention as examples the B'riat bat or sometimes called Simchat Bat, a ceremony introducing a baby girls into the covenant of Israel; new blessings and ceremonies to celebrate first menstruation; honoring the entrance of women into age and wisdom in a ceremony known as Simchat Chokhman; Rosh Chodesh (New moon) celebrations with their own liturgy; and Passover celebrations in which women focus the Seder (dinner celebration) into their redemption from the bondage of sexism between others (Adler, 69).
} 
Still, within the Conservative movement, the issue underwent much debate and scrutiny until the first woman was ordained as rabbi in 1985.

\section{Women Ordained as Rabbis in the Conservative Movement}

In her book, Women Who Would be Rabbis, Pamela Nadell recounts the stories of many exemplary women who performed all the duties of rabbis but were denied ordination.

Every time women would request admission to rabbinic school, their denial would be based on the argument that Judaism assigns women to certain spheres and duties, namely the home and raising children. ${ }^{59}$ Instead, women were steered toward different institutions, directed toward areas of Judaism related to teaching.

Most people believe that a rabbi is only the spiritual leader of a congregation, a person with high moral values and respects, who follows all the religion's laws and precepts. Even though that description generally encompasses what a rabbi is, there are other tasks he or she should perform. The word rabbi comes from the Hebrew "Rav," which means "teacher"- some people translate it as "teaching Torah"- therefore the main task of a rabbi is to teach, to pass along his or her knowledge to the congregation.

\footnotetext{
${ }^{59}$ For example Martha Neumark was the first of the early rabbinic candidates that was accepted in rabbinic school at the Hebrew Union College, but when in 1921 she petitioned the faculty an assignment for the High Holidays it triggered a big debate. People against female rabbis argued that Judaism assigns women certain sphere and duties, and since they have to get married and raise children, appear in public performing public duties would be very difficult, and they would face the reality of having to make a choice between their profession or the calling of mother and homemaking (P. S. Nadell 1998, 65). They kept arguing that excluding women from the rabbinate affirmed the Torah's wisdom in assigning man and woman their respective "spheres", however, women can participate in an array of avenues for "religious and educational work" (P. S. Nadell 1998, 67). However, those in favor argued that women with the required academic training could take on the responsibilities. Moreover, on the issue of motherhood, they argued that the rabbinate "Involves the totality of life to the preclusion of even the function and offices of motherhood." Furthermore, Rabbi David Neumark even asserted that "After a woman bore a child; she will be a better rabbi for the experience" (P. S. Nadell 1998, 70).
} 
There were some exceptional women who tried, in the early 1900s, to enroll in the Conservative Jewish Theological Seminary (JTS) in New York. ${ }^{60}$ However, women began to have a more active role within the movement in the early 1930s when Cyrus Adler, JTS's president, created the Women's Institute of Jewish Studies, an adult education forum that aimed at preparing participants "for leadership in women's work" (Nadell 1998, 177). However, the issue of women's ordination was not central yet, and without women pushing or pursuing the question, there was no need for debate. Every time a woman wished to study at the JTS, she was directed to its Teachers Institute, ${ }^{61}$ for which applicants needed to prove they could read biblical Hebrew, converse in modern Hebrew language, and display a broad understanding of Jewish history. By June 1935, 289 women and 202 men had graduated from the Institute (Nadell 1998, 181). On rare occasions, women did seek to go beyond the Institute.

\footnotetext{
${ }^{60}$ In the fall of 1903, Henritetta Szold entered JTS to become a rabbinical student; however she expressed to its president, Solomon Schechter, that she intended to study rabbinic essentials but had no desire of becoming a rabbi, "simply to train herself for work on the manuscripts" (Nadell, 57). In 1906 she ended her studies at the JTS and the issue of women's ordination in the Conservative Movement came to a temporary halt that would last for several decades.

${ }^{61}$ An example is the case of Gladys Citrin. In 1957 she wrote to the JTS president, Louis Finkelstein, a letter claiming that she had an extensive Jewish education and that she felt "capable of overcoming any barriers that may stand in the way of achieving [her] goal; to be a religious and cultural leader of [her] people" (Nadell 1998, 185). Finkelstein suggested she come and tour their "Teachers Institute," saying, "It is not possible for a woman to be ordained as rabbi in our tradition" (Nadell 1998, 186). He also believed that going to the Teacher Institute would "help prepare her to become a good wife and mother in Israel, a high priestesses in the sanctuary of her home" (Nadell 1998, 186).
} 
A new group called "Ezrat Nashim," led by young women committed to Judaism, emerged around the 1970s. ${ }^{62}$ In January of 1972, they prepared a position paper called "Jewish Women call for Change" which helped bring Jewish feminism out into the open. In it, they asserted: "Ultimately all of Judaism will have to come around." They also believed that women would no longer be satisfied with symbolic concessions and demanded a broad transformation of Jewish religious and communal life to make women, at last, equal (Nadell 2009, 163-164). These feminists were determined to transform all of Jewish life by educating themselves.

In December of 1977 the Commission for the Study of the Ordination of Women as Rabbis was convened, with the purpose of issuing a recommendation to the Rabbinical Assembly (Gordis, 8). In December of 1978, eleven commission members agreed that "There is no direct halakhic objection to the acts of training and ordaining a woman to be a rabbi, preacher, and teacher in Israel," and recommended the acceptance of qualified women in the seminary to be ordained as rabbis in the Conservative Movement (Nadell 1998, 194). In May of 1980, the Rabbinical Assembly went on the record as favoring the ordination of women. In 1983 the question of whether women should be admitted to the rabbinical program in the Seminary was put to vote and adopted 34 to 8 with one abstention. Robert Gordis concludes that it was a major step to overcoming the historic conception of male superiority and female inferiority:

By this act Conservative Judaism will have demonstrated that the Jewish tradition is truly viable and as sensitive to human needs and aspirations in

\footnotetext{
${ }^{62}$ I notice here that the name of the group has the same name of the women's gallery of the Temple, the one that some believe to have stemmed the tradition of having the mehitzah (division between men and women in the synagogue) that many feminists believe is restrictive for women.
} 
the present as it has been in the past. Above all, the ordination of women in Conservative Judaism will testify to the determination to press forward towards the fulfillment of the great command of the Torah "You shall do what is good and right in the eyes of the Lord" (Deut. 6:18) (Gordis, 12).

Therefore the ordination of women came as a natural culmination of the steady expansion of women's rights and responsibilities that started with, as stated by Moshe Davis, "the recognition that women needed a more significant role in the life of the synagogue" (Davis, 124). In the fall of 1984 twenty-three women entered the Seminary as rabbinical students; a year later, in May of 1985, Chancellor Cohen presided over the ordination of Amy Eilberg as "Rabbi, teacher, and preacher in American Israel, " $\mathrm{Ha}$ ' $\mathrm{Rav}$ Chana Beyla." Her ordination marked the beginning of admission to women in the Rabbinical Assembly, including Rabbi Beverly Magidson, who a decade earlier had first pressed for women to be Conservative rabbis (Nadell 1998, 214).

It is surprising that men in the United States' Reform movement were the ones to begin implementing changes to give women "equal"63 position in synagogue, because one might think that in a patriarchal tradition, men would have wanted to keep practices the way they were. Second wave feminism had a big impact on Jewish feminism; education became more accessible to women, and greater access to education meant that women started to learn more about Judaism. With increased knowledge of their faith, women sought ways to feel equal and included in it, and slowly changes were made. The ordination of women rabbis was a re-visioning of Judaism that began with the transformation of women's roles within the synagogue.

\footnotetext{
${ }^{63}$ I placed quotation marks around "equal" because some feminist still believed that those changes were not enough for women not to feel as "second class".
} 
When women began studying to become rabbis, many serious concerns were raised. What would congregations do about maternity leaves? What would the husband of a rabbi be called? Some people knew that the "dynamic of rabbi-congregational life would no longer be the same" (Nadell 1998, 166). Nonetheless, women offered a different perspective to the rabbinate, not only enriching the experiences of congregants, but relating to them in a different way. Within Conservative Judaism, at first, women were less interested than their Reform sisters had been in the issue of ordaining women rabbis. For them, tradition was more important, so they decided to focus on Jewish education and teaching rather than pushing ideas of equality and advancement of women within the movement. These issues would take center stage for women in the Conservative movement in the second half of the twentieth century. However, when the time came, the debate proved to be much more contentious than it had been within Reform Judaism. The fight between traditionalism and the modernization of religion was much tenser, and a great deal of judgment came from the Conservative elite, who preferred to steer women toward teaching and discourage them from pursuing a rabbinical career.

One thing is clear, the centrality of teaching — not only within the role of a rabbi, but for Conservative Judaism — is extremely important. Although some American women rabbis still believe they have not reached an absolute equal position with men rabbis, they do recognize the progress they have made. The case of the rabinas is different. While they share some issues with their American counterparts, rabinas still have a long way to 
go. In the next sections of this thesis, I will explore more deeply the differences and commonalities in their stories. 


\section{Chapter III}

\section{Latin America: Understanding the Region in Context}

Latin America is a vast region encompassing multiple economic, political, demographic, social, and cultural characteristics of its constituent countries. Moreover, within each country, gendered personal experiences are interwoven with factors such as ethnicity, class, migrant status, urban/rural residence, family and household characteristics, and sexual orientation, among others (Chant and Craske, 4). Each society is influenced not only by regional history, but by the intrinsic characteristics of its country including migration patterns, culture, and religious beliefs. In this chapter, I will explore women's issues and Conservative Judaism in the context of Latin American societies. This discussion will give the reader an understanding of the social context in which the rabinas live and work, and where their cultural characteristics are rooted. To this end, the chapter is divided in two parts: firstly, women in Latin America and secondly Judaism, particularly Conservative Judaism in the region.

Even across disparate countries, histories, and societies in Latin America, women are united in the shared experience of oppression; historically they have been treated as second-class citizens and alleged to be lesser than men. Their sexuality has been largely regulated by men and by what some would define as patriarchal governments. They have been confined to the domestic arena, and historically, have not held many positions of power in either politics or the workforce. In order to better understand the circumstances in which Latin American rabinas live and work in their respective countries, I will first 
examine women in Latin America: their general characteristics, history (including the influence of the feminist movement), perspectives on motherhood, and the current state of affairs for women in the region.

One needs to consider that the countries in which the rabinas are currently working are distinctive countries in the region because all currently have women as presidents. Laura Chinchilla is Costa Rica's president, and the country is one of the most developed countries characterized by a long democracy. It is one of the only countries that did not experience any military rule because they do not possess an army. Sao Paulo is considered the richest province in Brazil and is very advanced culturally. The first elected woman president, Dilma Rousseff, assumed power in January 2011. Argentina is also considered to be in the vanguard of social and political changes, and Cristina Fernández de Kirchner is its president of the country.

The second part of the chapter is focused on Conservative Jewish Latin America. In order to understand it, one needs to first learn how Jewish migrants arrived in the region and the circumstances in which they live. The different ethnicities and religious backgrounds across Latin America are part of what makes the region so unique. My research requires an understanding of the continent's Jewish composition and its origins. Furthermore, Jewish-Latin America is not homogenous since it consists of varied ethnicities and different Jewish denominations. The Conservative movement was established in the region with the creation of the Seminario Rabínico Latinoamericano in Buenos Aires, becoming the center of Conservative Jewish Latin America. Understanding the issues of women and feminism in Latin America as well as the history 
of the Conservative movement in the region will set the stage for the introduction of the rabinas and their stories.

\section{History of Women in Latin America}

In order to understand where Latin American women stand today, we must examine the history of women in the region. The relegation of women to the domestic arena dates back to pre-colonial times. Amerindian women were generally subordinated and segregated from public life. Nevertheless, they played important economic and social roles and were vital to the survival and welfare of their communities; women worked in agriculture, transmitted oral history, organized work in the villas, and raised children ${ }^{64}$ (Navarro and Sánchez Korrol, 6).

After the conquest of the Americas, the Catholic Church became the governing force within the continent, and the image of the Virgin Mary as a great mother to all ${ }^{65}$ was extremely influential across societies. Her image underscored the role of women as mothers and homemakers. The establishment of Convents in the sixteenth and seventeenth centuries presented an alternative life for white and some native elite women, who chose to go there in order to escape the control of men and live a "free life."66

\footnotetext{
${ }^{64}$ Moreover, in the Inka Empire, some women had a secondary position in priesthood, and there were also some goddesses in their religious life.

${ }^{65}$ It is then that one can understand the strong presence of the Virgin Mary in Latin America and her influence over different types of populations, either as the white Virgin Mary, or as a mestiza Virgen de Guadalupe.

${ }^{66}$ Outside the convents, women were under the control of their fathers until they married. As married women, they fell under the control of their husbands. In some cases, while living in certain convents, women were even able to enjoy their own possessions and elite status within the convent.
} 
Convents also offered educational opportunities and women could become literate, learn accounting, and enjoy and perform different types of arts. ${ }^{67}$

Influenced by the Enlightenment, the monarchy in the eighteenth century implemented administrative and fiscal reforms; among them, were changes promoting women's education. In Women in Latin America and the Caribbean, Marysa Navarro describes the importance of motherhood in education this way:

Enlightened reformers demanded the creation of new values in the population, and, because of women's crucial roles in instilling values in their children, "motherhood took on a civic function increasingly exalted in the writings of the time. And since mothers could fulfill their responsibilities only if they were themselves enlightened, reformers vigorously advocated the education of the Fair Sex' (Navarro 1999, 56).

In the second half of the eighteenth century, teaching orders for girls were established in several Latin American cities in which young girls were taught how to fulfill their roles as wives and mothers, while also gaining exposure to subjects like reading, embroidery, religion, sewing, and music. ${ }^{68}$

After the fall of colonial rule, the issue of women's rights reemerged in Latin American countries as women searched for different means of emancipation. By the mid-

\footnotetext{
${ }^{67}$ Convents performed several functions besides their religious one, such as economic (they gave loans and mortgages), social, and educational, thus becoming a very strong entity in colonial times. They were sustained by philanthropic work of the elite families and the wealth they were able to generate through their own businesses and work.

${ }^{68}$ For example, in Mexico City by 1802, some 3,100 girls studied in "70 convents, parish, municipal, and private schools" (Navarro 1999, 57). Furthermore, laic women from the elite also showed a great interest in women's education, and they opened the Colegio de la Enseñanza in 1754 in the capital of the viceroyship of Novohispano, as well as in Mendoza, Argentina, and in 1783 in Santa Fé de Bogotá, Colombia (Bidegain, 18).
} 
1800s there were a few journals that produced articles for women and even some women's journals; however they were mostly written by men and reached a narrow urban audience ${ }^{69}$ Often published every few years, ${ }^{70}$ they "remain a testimony of the desire to create a modern Latin American woman" (Guy, 170). Women began to mobilize into associations and participate in regional, national, and international forums. These journals and essays were the first steps taken towards women's emancipation (Sánchez Korrol, 85). There was an intellectual activity already developed by women, although small, that it is still proven to be influential nowadays. ${ }^{71}$ As Miller notes in her book:

The emergence of women novelists, poets, journalists, and political activists and the development of a shared feminist consciousness in the early twentieth century in certain nations of Latin America are directly linked to the presence in those countries of trends that combine to produce a process of modernization. Women intellectuals first found their voice and their audience- in Argentina, Uruguay, Chile, and Brazil, states that received hundreds of thousands of European immigrants, whose urban centers became true cities, and where social and political reform movements were mounted; and in Mexico and Cuba, where major social upheavals took place (Miller, 68).

By the nineteenth century the Church no longer enjoyed a pre-eminent place in politics, however it remained a powerful force in influencing and legitimizing family roles in which women were still portrayed as mothers and housewives and depended on men

\footnotetext{
${ }^{69}$ Only the elite and literate women were being reached by these works.

${ }^{70}$ Such as O Journal das Senhoras (Brazil, 1852-1855), El Aguila Mexicana (Mexico, 1826), and La Alborada del Plata (Argentina, 1870s and 1880s) (Guy, 170).

${ }^{71}$ One example is Soledad Acosta de Samper, a Colombian writer born in 1833 who was able to get an education in Paris at the age of thirteen that helped her intellectual development. She wrote the book La mujer en la Sociedad Moderna (The Woman in Modern Society) in 1859, in which she explores how women can and should get involved in the foundations of the nation, not only as mothers and wives, but also as agents of intellect and ambition, as well as in political terms.
} 
financially. ${ }^{72}$ In the first half of the twentieth century, religious women established and attended schools. The establishment of schools was important because it was another opportunity for women to gain access to education, particularly in those countries whose governments did not possess the economic means to support women's education. ${ }^{73}$ The institutions founded by these women had a great historical, political, and religious significance in the first part of the twentieth century; they developed a large social network which looked after the needs of many settlements of different social classes while also propelling the process of modernization ${ }^{74}$ (Bidegain, 63).

In contrast to the United States and Europe, women's suffrage was not a central concern for Latin American feminists at the beginning of the twentieth century, because on one hand, there was no history of effective male suffrage in countries of the region, and on the other hand, feminists could not agree on the value of their vote. ${ }^{75}$ Opponents of female suffrage argued that "politics was a masculine activity in which women, because of their very nature, should not be allowed to participate” (Sánchez Korrol, 92).

\footnotetext{
${ }^{72}$ Moreover, Chant and Craske help us understand the importance of the role of women as mothers by stating that the "Church's idealization of woman as a mother - expressed in references to 'madrecita santa' ('holy [little] mother'), 'el sagrado deber de ser madre' ('the sacred duty to be a mother'), and 'la madre sufrida y sacrificada('the suffering and selfsacrificing mother') - makes it difficult for women not to see motherhood as their destiny" (Chant and Craske, 135).

${ }^{73}$ Religious women showed a particular interest in women's education. They took part helping women not only with the project of reinstituting Catholicism but mostly helping the advancement of women through an education that would help them defeat their domestic role (Bidegain, 30$31)$.

${ }^{74}$ My own translation.

${ }^{75}$ See Miller discussion on different feminists' arguments for and against the issue of women suffrage (Miller, 86).
} 
Influenced by the North American women's success movement, in 1922 Latin American feminists ${ }^{76}$ organized women's associations in several countries joined by the newly formed Pan-American Association for the Advancement of Women, and suffrage became one of their main goals. Woman's suffrage was granted to women in Latin America in three different time periods, with Ecuador being the first country to grant it in 1929 and Paraguay the last in 1961.

Figure 1: Women's enfranchisement dates in Latin America

\begin{tabular}{llll}
\hline & & Post World-War & \\
Pre-World War II & & II & \\
Ecuador & 1929 & Venezuela & 1947 \\
Brazil & 1932 & Argentina & 1947 \\
Uruguay & 1932 & Chile & 1949 \\
Cuba & 1934 & Costa Rica & 1949 \\
& & Haiti & 1950 \\
World War II & & Bolivia & 1952 \\
El Salvador & 1939 & Mexico & 1953 \\
Dominican Republic & 1942 & Honduras & 1955 \\
Panama & 1945 & Nicaragua & 1955 \\
Guatemala & 1945 & Peru & 1955 \\
& & Colombia & 1957 \\
& & Paraguay & 1961 \\
\hline
\end{tabular}

Source: (Miller, 96)

The twentieth century proved especially important for women; as different qualities of womanhood were emphasized, women were able to make social, political, educational, and economic advances. Movies in the 1920s, radio in the 1950s and 1960s, and television in the 1970s, provided images of modern women, and the notions of

\footnotetext{
${ }^{76}$ Suffrage was passed in the United States by 1920 demonstrated that "Female vote was far from revolutionary in its impact ... It could be viewed as a step towards democracy..." (Miller, 97).
} 
womanhood in Latin America started to change. In addition, local circumstances, such as military rulings, revolutions, and counter revolutions were catalysts for the evolution of grassroots organizations with a strong female presence, some even exclusive to women.

\section{Women and Motherhood}

As mentioned in chapter I, I consider motherhood an important trait of the rabinas, one that is of vital importance to the role they play as leaders of their congregations. A further analysis of motherhood in Latin America is key to understanding why it is so influential to these women. In Latin America, "motherhood" has always been representative of women, because historically it has been their primary role. The importance of the mother is reflected historically in the fact that the mother is the only one staying with her children, while the father is absent. In colonial times men left their homes to fight, and in modern times, they leave their house to work. ${ }^{77}$ Motherhood links women to the "casa" (home), the main place in which they can act as mothers, educating and nurturing their children. Therefore most of their daily activities are related to the private. On the other hand, men are defined as breadwinners, and sustain their household by being active outside of the casa, in the public sphere. Euro-American feminists of the 1970s were uneasy with the private/public division; they argued that in patriarchies, where only the "public" seems to count, women had to "liberate" themselves from their houses and

\footnotetext{
${ }^{77}$ Chilean scholar Sonia Montesino, explains this fact with the concept of bastard, or huacho, and applies it on the fact that in Latin American countries women have to raise their children without a father figure becoming, so their children become huachos, therefore she places a greater importance on the role of the mother (Montesino, 275).
} 
assume public roles (Chant and Craske, 9). The concept of "marianismo",78 emerged around this time and still resonates nearly four decades later. It is used by some to argue that motherhood is an 'obstacle' for women, both inside and outside the home because it relegates them to domestic issues, preventing them from entering the workforce and taking an active role in social participation. For others marianismo presented motherhood as a source of power, "particularly a basis for political participation, identity, resistance and/or transformation" (Chant and Craske, 10). While I believe marianismo tries to revalorize women's attributes and roles as mothers, I do not agree with the more extreme interpretation in which motherhood makes women superior to men. This interpretation would be inverting the patriarchal model replacing it with a matriarchal one, losing sight of the ultimate gal of equality.

Motherhood, as a concept, proves useful to analyzing Latin American women.

Motherhood has given women a space for social action throughout the continent, especially against the state and/or in subversive ways. Furthermore social movements that arose in the 1970's and 1980's and focused on human rights and family welfare illustrate

\footnotetext{
${ }^{78}$ Marianismo was used first by political scientist Evelyn P. Stevens in her essay entitled "Marianismo: The other face of Machismo" published in 1973, in which she defines it as "The cult of female spiritual superiority which teaches that women are semi-divine, morally superior to and spiritually stronger than men" (Navarro 2002, 257). It is appropriate here to note that marianismo is not a religious practice, and Stevens argues that the veneration of the Virgin Mary within the Roman Catholic Church "provided a central figure and a convenient set of assumptions around which the practitioners of marianismo have erected a secular edifice" (Chant and Craske, 9). She expands on the idea of women's oppression by men, notwithstanding the fact that women are superior due to their biological connection with God. This concept was embraced by some and rejected by others. For example, Swedish anthropologist Kristina Bohman believes that Latin American women are not oppressed but rather enjoy privileges because of the importance given to motherhood. However, she also notes that "[Steven's] argument has to be seen in the light of both, class differentiation and of the patriarchal structure of the family" (Navarro 2002, 258).
} 
women's nurturing side. ${ }^{79}$ Linda Kerber defines the creation of women's social movements as "republican motherhood," because women "exercised their patriotic mission with their femininity and moral value. Its purpose [is] to ensure the virtue of the nation through their biological advantage as mothers" ${ }^{\prime 80}$ (Belucci, 270). Therefore women used traditional qualities like wifely devotion and motherly love to confront the terrorism perpetrated by the state, because the duty granted by those traditional roles held them responsible for preserving life (Belucci, 275). Thus, as noted by Molyneux, "The status of motherhood conferred a degree of protection from annihilation" (Chant and Craske, 11). For these groups of women, motherhood and social justice came hand in hand. Their status as mothers gave them not only the right to fight for their sons and daughters, but also protection, because as mothers they were extremely valued. Motherhood became a strategic useful identity for creating a movement. Groups of women like these, fighting not only for their own rights but for the rights of others, could be considered feminist groups. However, feminism is understood differently in Latin America and the issue there is much more complex than in the United States and Europe.

\section{Feminism in Latin America: a Brief History}

In chapter I, I defined the three major waves of feminism. I believe third-wave feminism was the one that most influenced the Latin American feminist movement, because it was

\footnotetext{
${ }^{79}$ One example is the case of "Madres de Plaza de Mayo" (Mothers of Plaza de Mayo) in Argentina. This group was constituted under the repressive regime of the "Junta Militar" (military junta) of the years 1978-1983, and it was composed of mothers fighting to find their sons and daughters "desaparecidos" (disappeared) under military ruling. They became the voices of thousands of parents and desperate families and friends searching for their love ones.

${ }^{80}$ My own translation.
} 
centered on the understanding of differences between women. ${ }^{81}$ To summarize feminism in the region, Miller provides a general overview of goals and trends of the movement in Latin America in her book Latin American Women and the Search for Social Justice: the period from around 1890-1938 is called one of "social motherhood" in which women's claims for change emphasized traditional gender virtues; the period of 1938-1958 is explained as one of democracy and the search for social justice, including the quest for suffrage; and the last period, between 1939-1973 is one of revolution and counterrevolution and one in which suffrage was granted. Looking at the historical changes within these periods in Latin America, one can conclude that the development of feminist theories and ideas went, and still go, hand-in-hand with social changes in the region. However they were not necessarily historically related to the ideas and changes propelled by feminist movements in the United States and Europe.

When it comes to Latin American feminism, the perception of the movement in the region is largely negative. Feminists are thought of by many as an "elite" group and there is a perception that the movement is composed only of professional women, which raises questions of ethnicity, class, and the supremacy of certain groups of women over others. The negative perception comes not only from women, but from men as well, who believe feminist movements highlight the supremacy of women over men, diminish men's position, and are generally anti-men. However, the goal of women who claimed to be feminists was to fight in order to change their position of subordination. These women were considered "exceptional," meaning that they engaged in activities that were not

\footnotetext{
${ }^{81}$ It was then understood that class and race, for example, influenced women differently.
} 
commonly associated with women (such as pursuing higher education or education in "masculine" fields, travel, political participation, and working outside their homes), therefore becoming role models, regardless of their class or ethnic background (Craske, 166). Theirs was not a fight for supremacy, but a fight for equality, as articulated by Dr. Alicia Moreau de Justo. ${ }^{82}$ Moreau de Justo stated, "For me feminism is not apart from social reality. The woman liberates herself along with the man and not against him" (Sánchez Korrol, 84). Throughout time, the movement sought to find a more unifying discourse — one beyond issues of inequality, political, and social change, ${ }^{83}$ and that included ideas of motherhood and other domestic concerns (Craske, 166).

Many of the precursors of the movement in Latin America were Catholic women who began their "public life" as militants of the Church. These women recognized that they had a "different mission" while searching for equality with men. This mission was a central concern at the International Feminist Congress held in Buenos Aires in 1910:

The belief in women's 'different mission' lies at the heart of feminist movements in Latin America and differentiates them from the predominant form of feminism that developed in England and the United States, where equality with men was the goal, and gender differences were denied or at least played down. In the Latin American context the feminine is cherished, the womanly - the ability to bear and raise children, to nurture a family, is celebrated. Rather than reject their socially defined role as mothers, as wives, Latin American feminist may be understood as women acting to protest laws and conditions which threaten their ability to fulfill that role. Moreover, there is an explicit spiritual or moral content to

\footnotetext{
${ }^{82}$ A physician, politician, and human rights activist who lived in Argentina, mainly recognized for her fight for women's political participation and the right to vote. She published the wellknown book La Mujer en la Democracia (The woman within democracy) in 1945. She died in 1986 at age 101.

${ }^{83}$ In some cases, men fought alongside them helping the cause of women's rights.
} 
the declarations of Latin American feminist which have strong parallels with feminist thought as it developed in Catholic Europe (Miller, 74).

This passage also demonstrates the centrality of motherhood for Latin American feminists, thus rejecting the notion of the movement as "anti-family" and "anti-men." Motherhood became the way women fought for their own rights and for the rights of others and it drove women into social movements, politics, and the workforce. Hence, education was one of the feminists' most important causes because it would enable women to "better fulfill their honorable and socially indispensable roles as mothers" (Sánchez Korrol, 84).

Craske argues that "The challenge of popular feminism has both enriched and brought problems to feminism as a movement in the region. Indeed, there is a question of whether feminism remains a useful concept when discussing the life of Latin American women" (Craske, 163). I believe it does, if we take into account that Latin American feminism includes the feminine as well, and embraces womanhood as well as motherhood in the search for equality. It is important to focus not on the oppression suffered by women throughout centuries, but on how their female and feminine attributes can help in the search for equality. I believe it is not a matter of gender supremacy, but of gender balancing, in which both men and women complete and perfect each other. With the creation of groups of women fighting for their rights, and the influence of some feminist ideas, women in Latin America are now gaining their independence and finding a new place in society. 


\section{Toward a New Millennium}

By the beginning of the twenty-first century the gap between the rights of men and women had narrowed. Latin American women had made significant advances; they enjoyed increased political and social participation, greater and easier access to education, legal support for their personal advancement, and a better legal system for dealing with their individual, conjugal, and domestic lives. These changes meant that a woman had the necessary freedom to choose the course of her life.

Feminism and women's participation in social movements have changed what it means to be a woman outside the traditional boundaries. Some of these transformations are reflected in the legal changes protecting women's rights, for example in divorce laws, maternity leaves, and reproductive rights. Safa notes the way in which women are forging new relations with the state, "based not on subordination, control, and dependence, but on rights, autonomy, and equality" (Sánchez Korrol, 105). This has clearly increased women's visibility in political, institutional, and social life. For example, some of the changes include women's ministries and required quotas within the electoral system among others. Notable women were appointed to public office such as Chilean Nobel Laureate Gabriela Mistral that served as special ambassador to the League of Nations and the United Nations, and Mexican writer Rosario Castellanos and Carmen Naranjo of 
Costa Rica were ambassadors to Israel (Sánchez Korrol, 96). Furthermore, Latin America has had several women elected presidents. ${ }^{84}$

Nowadays the division between the private and the public has been narrowed and women in all sectors of Latin American society are engaged in greater shares of "productive" work outside their homes. One of the main factors that helped women becoming part of the workforce was education. On the basis of a comparative work on Buenos Aires and Mexico City, Cerruti argues that "More educated women are not only more likely to work, but they are also likely to stay in the labor force for longer periods, and to express greater commitment to their jobs (partly because they have access to more rewarding jobs)" (Chant and Craske, 207). In some countries women outnumber men in tertiary or higher education; ${ }^{85}$ moreover, women even surpass the men in careers requiring a degree from a university ${ }^{86}$ (Maier, 337).

Another factor influencing the rise in the number of women in the workforce is economic need. Constitutional changes giving women greater rights over their children and family, protecting them against abuse and, in some cases, increasing their reproduction rights, have pushed some women toward singlehood, and sometimes toward becoming the sole heads of household. However, workplace equality remained elusive. In

\footnotetext{
${ }^{84}$ Besides the three presidents previously mentioned in this work, there were also Violeta Chamorro from Nicaragua in 1990, Mireya Moscoso from Panama in 1999, Sila María Calderón as governor of Puerto Rico in 2001, Michelle Bachelet from Chile in 2006.

${ }^{85}$ Please refer to the Latin American and the Caribbean Report of the UNESCO report for Statistics Section 2 published in 2000 with data provided by countries covered in the report within the framework of (Unesco 2001).

${ }^{86}$ As an example Maier cites Cuba, in which women constitute $75 \%$ of all enrolled university students studying for career that require a degree (Maier, 350).
} 
some countries, ${ }^{87}$ professional women outnumbered men; nonetheless, in high-paying, upper management positions the ratios were reversed (Sánchez Korrol, 96). In certain cases, paid work represents a burden for women, because usually domestic gender relationships are transferred to the workplace (Craske, 194). Furthermore, Safa and Butler Flora argue that paid work does not necessarily increase women's status but does increase their work load. However, it also provides them with a greater voice in their homes and community (Safa and Butler Flora, 115).

Women in Latin America have made impressive steps towards gender equality, however, they came at a cost, adding to their responsibilities and sometimes increasing the burden of their labor. The burden is in part because men have been rather slower than women in adapting to gendered changes in the home and labor market (Chant and Craske, 254). Men are still not as involved in domestic tasks as women. Therefore, while gains in education and reproductive rights have helped women become more independent, they now not only work outside the home, but are still expected to tend to housework and care for children. Furthermore, Latin American society remains conservative in its adherence to traditionally accepted roles for women. One of these roles is motherhood. As previously noted, though motherhood was sometimes criticized by feminists, it still defines womanhood to women in the region and so remains important to their lives.

${ }^{87}$ For example Brazil and Argentina (Sánchez Korrol, 96). 


\section{Jewish Migration to Latin America}

Latin America, including Central, South America, and the Caribbean has a 0.57\% Jewish population, ${ }^{88}$ making it the third largest Jewish population in the world as measured by percentage of total population after Israel and the United States (Dashefsky, DellaPergola and Sheskin, 65). Nevertheless, the conditions in which Jews nowadays live in the region differ from their conditions in other parts of the world. It is important to understand when and under what circumstances Jewish immigration to the region occur in order to understand the current situation of the Jewish community in Latin America.

\footnotetext{
${ }^{88}$ It is important to note that is extremely difficult to calculate Jewish population because different factors are involved. Dashefsky, DellaPergola, and Sheskin count core Jewish population which "includes all persons who, when asked in a socio-demographic survey, identify themselves as Jews; or who are identified as Jews by a respondent in the same household, and do not have another monotheistic religion. Such a definition of a person as a Jew, reflecting subjective perceptions, broadly overlaps but does not necessarily coincide with Halakhah (Jewish law) or other normatively binding definitions. Inclusion does not depend on any measure of that person's Jewish commitment or behavior in terms of religiosity, beliefs, knowledge, communal affiliation, or otherwise. The core Jewish population includes all converts to Judaism by any procedure, as well as other people who declare they are Jewish even without conversion. It is also customary to include persons of Jewish parentage who claim no current religious or ethnic identity. Persons of Jewish parentage who adopted another monotheistic religion are usually excluded, as are persons who in censuses or socio-demographic surveys explicitly identify with a non-Jewish religious group without having formally converted out" (Dashefsky, DellaPergola and Sheskin, 9).
} 
Figure 2: Jewish Population per Region

\begin{tabular}{|l|l|l|l|}
\hline Region & \multicolumn{1}{|c|}{$\begin{array}{c}\text { Jewish } \\
\text { population }\end{array}$} & $\begin{array}{c}\text { Total Region } \\
\text { Population }\end{array}$ & \multicolumn{1}{|c|}{$\begin{array}{c}\text { \% of Jewish } \\
\text { Population }\end{array}$} \\
\hline Latin America & 335,100 & $588,648,000$ & $0.57 \%$ \\
\hline United States \& Canada & $5,650,000$ & $343,018,000$ & $1.65 \%$ \\
\hline Europe (including West & $1,455,900$ & $80,9334,000$ & $0.18 \%$ \\
\hline $\begin{array}{l}\text { Israel } \\
\text { Bank and Gaza) }\end{array}$ & $5,703,700$ & $11,222,100$ & $51 \%$ \\
\hline Other Asia & 37,800 & $4,078,993,900$ & $0.001 \%$ \\
\hline Africa & 76,200 & $1,033,043,000$ & $0.01 \%$ \\
\hline Oceania & 115,200 & $35,838,000$ & $0.32 \%$ \\
\hline Total & $\mathbf{1 3 , 3 7 3 , 9 0 0}$ & $\mathbf{6 , 3 7 0 , 3 2 3 , 8 0 0}$ & $0.21 \%$ \\
\hline
\end{tabular}

Source: (Dashefsky, DellaPergola and Sheskin, 65-68).

Bearing in mind the vastness of Latin America - the varying religious norms, politics and social characteristics of its constituting countries - is important to understanding Jewish migration, because it did not happen at the same pace or in the same way in every country. Jewish settlements in Latin America date back to the arrival of the Spanish and Portuguese; however there is not a lot of material written about the Jewish presence in Latin America during colonial times. Marjorie Agosín writes that mestizaje ${ }^{89}$ has been the most outstanding characteristic of the Americas, but even so, the Jewish presence has gone almost unnoticed by historians, and its history "remains largely unwritten, filled with secrets, forgotten memories, and stories yet to be told" (Agosín, xii). Once settled in their new homelands, Jewish immigrants were influenced by the local culture of the receiving country, making Jewish-Latin America non-homogenous. ${ }^{90}$ As Robert Levine

\footnotetext{
${ }^{89}$ This term refers to the mix of races in Latin America, in particular people with European origin and Amerindians.

${ }^{90}$ I choose to use "Jewish-Latin America" instead of "Latin American Jewry" following Jeffrey Lesser and Raanan Rein's formulation because it " emphasizes national identity without denying the possibility of diasporic identity" (Lesser and Rein 2006, 250).
} 
remarks, "the conditions faced by newcomers to Euro-American countries such as Chile, Argentina, and Uruguay differed significantly from conditions in Indo-American countries such as Mexico or Peru.” Jews in South America became part of the process of urbanization and social transformation in the region, while elsewhere they remained, for the most part, isolated and with relatively unchanging social patterns (Levine, 71)

Judaism has been present in Latin America since its conquest, when Jews and conversos $^{91}$ escaping from the Inquisition in Spain and Portugal settled in different countries (Elkin 1998, 8-15); however they were not a significant community except in Curacao, Brazil, and for a brief time, Peru (Merkx, 5). Contemporary Latin American Jews are a product of nineteenth and twentieth century migrations (Elkin 1998, 21). Since then, Jewish migrants arrived in different waves and from different countries, searching for economic opportunities or escaping persecutions in their homelands. Between 1880 and 1914, all Latin America countries received both Sephardic and Ashkenazi Jewish immigrants $^{92}$ (Elkin 1998, 68). During the twentieth-century Latin America received a large wave of immigrants escaping World Wars I, II, and the Nazi regime. In their new homelands, these immigrants were faced with the region's diverse economies and cultures, and because many societies were predominantly Catholic, Jews remained outsiders. In order to retain their own ethnic identities, Jews congregated and lived in

\footnotetext{
${ }^{91}$ Conversos (converts) were secret Jews that converted to save their lives and properties; nonetheless, they secretly continued to practice Judaism. They were also called marranos (swine).

${ }^{92}$ A survey commissioned by the American Jewish Committee in 1917 estimated a total of 150,000 Jews living in South and Central America and the Caribbean, and between 110,000 to 113,000 were estimated to live in Argentina (Elkin 1998, 68-69).
} 
closed communities, which might have caused others to perceive them as an isolated community within the region. By the mid-twentieth century, assimilation was still rare.

Jews prospered economically and gained acceptance in periods of political stability and economic expansion in the region; nonetheless, when the skies darkened, ${ }^{93}$ Jews became scapegoats, second-class citizens, and targets of new forms of antisemitism. As Levine explains, Jews' patriotism was challenged and they were called “"cosmopolitan garbage' (as in Argentina) or 'enemies of the revolution' (as in Mexico or Nicaragua) [...] In Argentina and Uruguay, nativist campaigns charged Jews with being unassimilable" (Levine, 73). However, Jews did want to be part of and accepted by their "new nations." Gordon and Elkin affirm that Jews of Latin America "have faced a process of acculturation without structural assimilation" (Schers, 291). In doing so, they adopted the national language, culture and accepted values, beliefs, and attitudes of the countries they lived in. Still, some groups completely isolated themselves (such as some Orthodox communities) becoming less acculturated (Schers, 292). The issues of acculturation, assimilation, and identity are complex and deserve further development, but as it falls outside the scope of this thesis, I will not develop it any further.

Nevertheless, I do believe that a more specific analysis should be conducted in order to better understand the reasons behind the acculturation (or lack thereof) for Jews in Latin America. Nowadays, Jews are integrated in Latin American societies, and as Elkin remarks, "Much of the immigrants' cultural heritage has now been left behind them"

\footnotetext{
${ }^{93}$ Levine gives the example of the semana trágica (the tragic week) in January of 1919 in which hundreds of Jews were killed in xenophobic rioting by the police and paramilitary. This event is also known as the "first pogrom" in Latin America.
} 
(Elkin 1987, 323). As a way of gaining acceptance and equality in a society, Jews of Latin America have learned to balance both their religiosity and their cultural identity. Nonetheless, those who identify primarily as Jews constructed their own private societies with large organizations as an umbrella for the smaller ones. ${ }^{94}$ Although antisemitism is still strongly experienced throughout the region (more in some countries than in others), assimilation is occurring, and Jews are accepted as part of the society.

Jewish religiosity in the region is a separate issue to be considered, because not every Jew in Latin America lives a Jewish life. Assimilation plays an important role in renouncing religious practices, as Jews intermarry and lose their personal Jewish identity. Elkin tells us that Jews have "voluntarily abandoned Jewish heritage in favor of an unalloyed national identity, despite the fact that there were few, if any, national institutions prepared to incorporate them together with their inherited culture." Furthermore, Elkin is certain that "Abandonment of the Jewish heritage in almost always couched in secular terms: there are almost no conversions to Catholicism" (Elkin 1980, 213). Additionally, Schers and Singer argue that Jewish contact with the general population of the region and the decrease in cultural, religious, and behavioral characteristics of the Jewish population increase the commonalities between the new generation of Jews and the surrounding population (Schers and Singer, 242). I believe that acculturation can also be a way of fitting into a society that is still highly influenced by antisemitism. Another important factor is the religious affiliation that Jews have. As

\footnotetext{
${ }^{94}$ These umbrella organizations were created in the 1930s as a response to the antisemitics attacks characteristic of that decade. For example the DAIA in Argentina was created in 1935. These umbrella organizations in Latin America were related to the World Jewish Congress and in 1964 established the Congreso Judio Latinomaericano (Latin American Jewish Congress) (Zadoff and Avni, 511).
} 
previously mentioned, the Orthodox movement has been in the region since the beginnings of Jewish migration. Later, Conservative and Reform movements emerged in the twentieth century as an alternative to Orthodoxy. I would like to stress that neither the Orthodox nor the Conservative movements in Latin America function the same way they do in the United States. In the next section I will present a general view of the characteristics of both movements, with an emphasis on Conservative Judaism in the region and its practices. 
Figure 3: Total and Jewish Populations of Latin America, by Country 1960 and 2005

\begin{tabular}{|c|c|c|c|c|}
\hline & $\begin{array}{l}\text { Total } \\
\text { Population }\end{array}$ & $\begin{array}{l}\text { Jewish } \\
\text { Population }\end{array}$ & $\begin{array}{l}\text { Total } \\
\text { Population }\end{array}$ & $\begin{array}{l}\text { Jewish } \\
\text { Population }\end{array}$ \\
\hline & \multicolumn{2}{|l|}{1960} & \multicolumn{2}{|l|}{2010} \\
\hline Argentina & $20,248,000$ & 310,000 & $40,666,000$ & 182,300 \\
\hline Bahamas & - & - & 346,000 & 300 \\
\hline Bolivia & $3,311,000$ & 4,000 & $10,031,000$ & 500 \\
\hline Brazil & $62,725,000$ & 86,038 & $195,423,000$ & 95,600 \\
\hline Chile & $7,298,000$ & 30,000 & $17,135,000$ & 20,500 \\
\hline Colombia & $13,522,000$ & 9,000 & $46,300,000$ & 2,700 \\
\hline Costa Rica & $1,072,000$ & 9,000 & $4,644,000$ & 2,500 \\
\hline Cuba & $6,466,000$ & 11,000 & $11,204,000$ & 500 \\
\hline Curaçao & 148,000 & 1,000 & 138,000 & 300 \\
\hline $\begin{array}{l}\text { Dominican } \\
\text { Republic }\end{array}$ & $2,797,000$ & 600 & $10,225,000$ & 100 \\
\hline Ecuador & $4,007,000$ & 2,000 & $13,775,000$ & 900 \\
\hline El Salvador & $2,434,000$ & 250 & $6,194,000$ & 100 \\
\hline Guatemala & $3,546,000$ & 1,000 & $14,377,000$ & 900 \\
\hline Honduras & $1,282,000$ & 150 & $6,700,000$ & 200 \\
\hline Jamaica & $1,630,000$ & 2,200 & $2,730,000$ & 200 \\
\hline Mexico & $32,348,000$ & 25,700 & $110,645,000$ & 39,400 \\
\hline $\begin{array}{l}\text { Netherlands } \\
\text { Antilles }\end{array}$ & - & - & 308,000 & 200 \\
\hline Nicaragua & $1,578,000$ & 200 & $5,570,000$ & 60 \\
\hline Panama & 995,000 & 2,500 & $3,508,000$ & 8,000 \\
\hline Paraguay & $1,677,000$ & 2,000 & $6,460,000$ & 900 \\
\hline Peru & $10,213,000$ & 3,500 & $29,496,000$ & 2,000 \\
\hline Puerto Rico & - & - & $3,998,000$ & 1,500 \\
\hline Suriname & 232,000 & 1,000 & 525,000 & 200 \\
\hline Trinidad & 789,000 & 400 & $1,305,000$ & 10 \\
\hline Uruguay & $2,700,000$ & 50,000 & $3,372,000$ & 17,500 \\
\hline Venezuela & $6,320,000$ & 8,000 & $29,044,000$ & 12,000 \\
\hline $\begin{array}{l}\text { Virgin } \\
\text { (U.S.) }\end{array}$ & - & - & 109,000 & 500 \\
\hline $\begin{array}{ll}\text { Total } & \text { Jewish } \\
\text { Pop. } & \\
\end{array}$ & 552,038 & & 389,600 & \\
\hline
\end{tabular}

Source (Lesser and Rein, Introduction 2008, 6) and (Dashefsky, DellaPergola and Sheskin 2010, 60-63). 


\section{Religious Considerations: The Conservative Movement}

Religiosity was not a main concern for early immigrants; despite certain exceptions, they "tended to be irreligious or antireligious in orientation" (Elkin 1987, 311). Their main concern was settling into their new countries, which was believed by some to be a temporary home, while others were ready to make it a permanent one. In order to settle into the new countries, Jews first created institutions that were necessary to carry out more practical tasks; ${ }^{95}$ congregational religious organizations were not among them. However, when they did face the task of establishing religious organizations, they brought Orthodox rabbis from abroad and established Orthodox congregations. ${ }^{96}$ Orthodox synagogues were the only religious congregational establishments until the late $1930 \mathrm{~s}^{97}$ and were characterized by a "closed" mentality, in the sense that no innovations were incorporated into religious rituals and customs. By 1967 most of Latin American Jewish communities professed Orthodoxy (S. B. Liebman, 25).

\footnotetext{
${ }^{95}$ Those institutions were Jewish cemeteries, schools, and mutual aid societies. Moreover, as noted in the Encyclopedia Judaica, for the most part, "the organizations were molded after the congregations in Western European countries from which their founders originated" (Zadoff and Avni, 510).

${ }^{96}$ Elkin presupposes that they did so as a way of making sure that things were going to be done correctly (Elkin 1987, 311). Moreover, Abraham Monk when referring specifically to the case of Argentina in his article in 1958 writes that young people did not want to identify with religion because it was a "matter of ridicule". He also touches on the issue of Orthodoxy and its rabbis saying that with exception of one, Argentina had at the time he wrote the article "Orthodox rabbis who stubbornly preserved the European patters" (Monk, 18).

${ }^{97}$ At the beginning, Congregación Kol Shearith Israel in Panama City was the only one to have a rabbi of Reform tendencies. Brazil was also a pioneer and in 1938, São Paulo's Congregação Israelita Paulista adopted Reform from the start; in 1970 they employed a Reform rabbi from the United States. Rio de Janeiro's Associação Religiosa Israelita also adopted Reform Judaism employing in 1980s an American-trained Argentine rabbi (Elkin 1998, 171).
} 
The complexity of Jewish religiosity in Latin America is great, and is also mixed with the issue of identity. Though I will not be developing the issue of Orthodox Judaism in Latin America, for the purpose of this thesis, is important to clarify some of the unique characteristics of its congregations in the region. One distinction is that not everybody attending Orthodox congregations in Latin America lives an Orthodox life. On the contrary, some practice Judaism like Conservative Jews do in the United States. ${ }^{98}$ Elazar and Mintz Geffen argue that for whatever reason, these people do not want to "formally identify with a group that actually says that it changes Halakhah and makes things easier (for that is how it is perceived in their minds) and does not simply close its eyes to individual practice while maintaining a certain public standard of observance" (Elazar and Mintz Geffen, 131). Orthodox standards are then considered "ideal" in Latin America and therefore a lot of Jews believe that by attending services (which they do only on special occasions or high Holidays) in an Orthodox congregation, they publicly validate their religiosity and are doing "what is right." This was not appealing to younger people who were trying to shed their connections with their parents' countries of origin, while adjusting to their new home in Latin America. ${ }^{99}$ The Reform and Conservative ${ }^{100}$

\footnotetext{
${ }^{98}$ Seymour Liebman notes as an example in his article a small Conservative congregation in Mexico whose members are English-speaking people who rarely held services on Saturday or on most Jewish Holidays. In contrast, another Conservative congregation composed mainly of Spanish-speaking, mostly Mexican-born Jews, had an Orthodox rabbi conducting services in an Orthodox manner except from the mixed-seating. "Conservative is resented by the elders since, to them; it offers only a license to violate many Orthodox precepts. It was accepted by the young Mexican Jews because it legitimized what they had been doing or, rather, not doing. They, with some cause, find aspects of Mexican Orthodoxy unpalatable, but they have no concept of the philosophy of Conservatism" (Liebman, 25).

${ }^{99}$ In her essay, Elkin explains that since immigrant Jews lacked a local history with which to identify, they relied heavily on the ties they had to their communities overseas, and these ties grew stronger, particularly with communities in Israel (Elkin 1987, 310).
} 
movements were driven by a younger generation in an attempt to make a Jewish "aggiornamiento 101 " accessible to everyone. For the newly-born Latin American generations there was a need to change. Rabino Skorka explains that until the 1970s the pillar of young Jewish- Argentina was the Zionist movement, which yielded many important fruits (such as kibbutzim funded in Israel by people trained in Argentina in the 40s and 50s). However, the "influence of Zionism vanished and Jewish Youth sought new horizons, among them revolutionary causes." Therefore began "the great development of the Conservative communities in Argentina. The task at hand was to show young people a modern way of practicing Judaism" (Skorka, 241-242). I would like to note that Argentina was the precursor in founding Conservative congregations, and that the process took a little longer in the rest of Latin America. The establishment of the Seminario Rabínico Latinoamericano in Buenos Aires represented the "official entrance" of the Conservative movement in Latin America. ${ }^{102}$ Nonetheless, the Conservative movement in Latin America does not work the same ways as it does in the United States. Conservative congregations in the region tend to be similar to Reform congregations in the United States. The reason behind this is still not clear, and deserves further research.

\footnotetext{
${ }^{100}$ Unlike in the United States, these two movements are not as clearly distinguished in Latin America, and some of the practices of Conservative congregations might be considered Reform characteristics in the United States. Eleazar and Mintz Geffen note, for example, how Reform synagogues can be regarded as Liberal, Progressive or just Reform, "the terms mean different things in different places, including traditional or Conservative in some places" (Elazar and Mintz Geffen, 130).

${ }^{101}$ This term is used by Elkin throughout her many works, referring to a way of bringing Judaism to present times as well as the present situation, becoming an integral part of Latin America.

${ }^{102}$ Even though the Conservative movement is still growing in the region, it still has fewer adherents than the Orthodox movement (Elazar and Mintz Geffen, 130).
} 
Figure 4: Masorti Congregations in Latin America

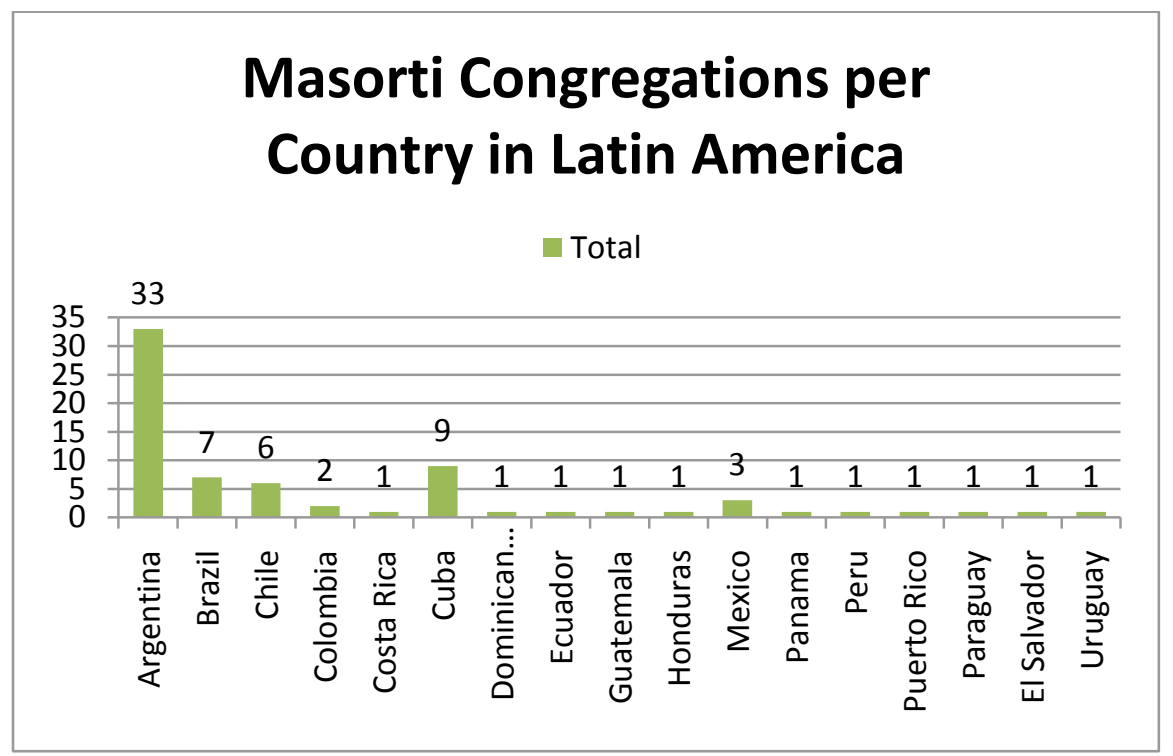

Source: (DevArt)

\section{The Seminario Rabínico Latinoamericano}

Rabbi Bronstein ${ }^{103}$ tells us that the story of the Conservative movement in South America goes as far back as 1862, "when two lonely Alsatian Jews, praying in a park in Buenos Aires, promised themselves that by the following Yom Kippur (Day of atonement), they would daven (pray) in their own synagogue" (Bronstein, 238). Years later, the first synagogue, Templo de Libertad, was created. Almost one hundred years after, in 1959, the late Rabbi Marshall T. Meyer, a New Yorker, arrived to that same synagogue and became the young people's rabbi (Bronstein, 239). The work of Rabbi Meyer had a tremendous influence in the region, making him the 'father of the Conservative movement in Latin America.' In 1962 he founded the Seminario Rabínico

\footnotetext{
${ }^{103}$ Argentine born, he was ordained at the Seminario Rabínico Latinoamericano in 1982 and has been the rabbi of a congregation in Lima, Peru since 1985. He has also served as vice president of the Latin American Region of the Rabbinical Assembly.
} 
Latinoamericano which today holds his name in blessed memory, and quotes as its motto the Prophet Isaiah, "atem aydai," meaning "You are My Witnesses" (Szteinhendler, 234). It is important to note that when Rabbi Meyer arrived to Argentina, he did not have explicit intentions of founding the Seminario nor he was sent by the Jewish Theological Seminary in New York to do so. A few years after his arrival, the American Movement gave Rabbi Meyer its blessing when he began establishing a network of Conservative congregations through the Seminario. He also established Machane (camp) Ramah in Comunidad Bet-El, as well as a day school and a youth movement (Elazar and Mintz Geffen, 132). The Seminario filled a need for Spanish-speaking people to have an education based on religious and secular modes. Associated with the Jewish Theological Seminary of New York City, the Seminario presented an opportunity to remove barriers and offer alternative ideas to the Orthodox community of that time in Argentina. In his essay, Szteinhendler notes:

Soon people learned about Conservative Judaism, whose rabbinate offered a promise of religious services where celebration was held not merely with systematic and formal prayer, but where there was also an exaltation of each religious experience, each melody, each tefillah (prayer) (Szteinhendler, 235).

Furthermore, according to Elkin, the Seminario "Reversed the obsolescence of Jewish tradition as practice in Latin America by training a generation of young women and men to assume leadership roles in their communities" (Elkin 1998, 172). In its beginnings it served as pre-seminary for rabbis; they could begin their studies there but needed to finish them in the United States or Israel to receive their ordinations. A later increase of funds and the establishment of an academic staff made possible ordinations of Spanish- 
speaking rabbis at the Seminario. In order to become a Conservative rabbi, students were required to have a bachelor's degree from an accredited university. The board of the Seminario believed that "If a revival of Jewish spiritual way [had] to happen in Latin America, it [could] only be achieved through a rabbinate that [was] in contact with both secular modern thinking, as well as with classical sources of Jewish thought and belief" ${ }^{104}$ (R. M. Meyer, 188). These days, rabbis ordained at the Seminario serve communities throughout Latin America as well as in some congregations in the United States and Israel (Szteinhendler, 337).

Many changes were implemented through the Seminario in the Latin American Conservative movement. One of the biggest fears faced by the Conservative community in Latin America is assimilation, especially of young people, through intermarriage and indifference. As an attempt to reverse this trend, Rabbi Meyer instituted a process of conversion, similar to that in the United States, which encouraged the formation of new Jewish families. Conservative synagogues are nowadays filled with young families and children, and women enjoy equal participation in congregational life and liturgy. The Seminario became the academic, cultural, and religious center of the Conservative Jewish Movement (Masorti) in Argentina and Latin America, whose main goal was to train and ordain rabbis to spread and perpetuate Judaism in Latin American communities. However its function is not limited to ordinations; it offers courses in Jewish education (including a Jewish teaching degree), primary education, conversion, non-formal education and youth leadership, and liturgical singing. Moreover, hundreds of schools, clubs, libraries, and

\footnotetext{
${ }^{104}$ My own translation.
} 
cultural centers which were once heavily secular have been influenced by the Seminario ${ }^{105}$ (Bronstein, 239). Rabbi Meyer spoke to the hearts of a younger generation of Argentine Jews, earning their respect and admiration. Many rabinas were influenced by his work and character in different ways.

The issue of identity for a Jewish Latin American person is still not clear. In Latin America, outside the Jewish communities, it is still hard to define Jewish people and their place in society. The question of identity as being Judaism or the nationality of the person is still not clear. Even though the issue of Jewish identity is not the scope of this research, is important to mention it as it is still present in the Latin American society.

I have presented in this chapter an overview of the situation of women as well as of Conservative Judaism in Latin America. It should be taken into account that each country has different circumstances, therefore the situation of Jews and women could slightly differ from country to country. For example, in Conservative congregations in Peru women do not read from or bless the Torah, even though Conservative Judaism is considered egalitarian there. Moreover, in some other congregations women are allowed to read from the Torah only on their Bat Mitzvah ceremony. Jews are still considered a minority in each Latin American country and there is still a lot of ignorance in the region of what Judaism is. In some cases, they remain segregated and are still victims of antisemitism. Furthermore, even today, I encounter comments like, "But what are you,

\footnotetext{
${ }^{105}$ Rabbi Bronstein cites the example of a rabbinical student, who was appointed in 1975 to club Hebraica in Buenos Aires to conduct services in the club's country place 30 kilometers outside the city, and since then, many bar and bat mitzvah ceremonies have been held. "The same could be said about Montevideo, Lima, Santiago, Bogotá, Mar del Plata, Sao Paulo, Rio de Janeiro, and many other Jewish centers" (Bronstein, 339).
} 
Argentine or Jewish?” proving the difficulty for Jews of integration into societies. This is one of the paradoxes intrinsic to Latin American Jewish identity: is it possible to participate in both parts of a Jewish-Latin American identity without living a polarized life? I believe it is, but it depends on the willingness of others to accept Jews as a different, yet also integral part of society.

As it pertains to women, some Latin American countries are more open to their advancement and some are still reluctant to grant them more open participation in society. It could be argued this is due to the "machista" mentality, that men are not yet ready to be led by a woman, or that some societies are still influenced by traditional ideas of the role of women. Nonetheless, I have to recognize the progress made by women in the public sphere. Changes to legislation protecting women's rights have made it possible for women to study, work, and actively participate in politics. However, we are only at the beginning of these changes and more work remains to be done as elsewhere in the world.

The traditional roles they play as women and their Jewish identity influence Latin American rabinas and their work. Their very womanhood represents a struggle, as they fight to prove themselves and gain acceptance. However, along with womanhood comes motherhood, and is motherhood — and all that comes with it — that motivated them to become rabinas. It is motherhood that drives them each day to fulfill their jobs as teachers whose main goal is to perpetuate Judaism for generations to come. In the following chapters, I will present their life stories, which are filled with passion, love for Judaism, and love and pride for who they are, Latin American rabinas, and their accomplishments. 


\section{Chapter IV}

\section{Meeting the Rabinas: My Fieldwork Experience}

The idea of researching Latin American rabinas came to me back in September 2009 while I was taking a course on Latin American women and religion at Florida International University. As part of the course requirements I had to write a research paper on a topic related to women and religion in Latin America. As a Latin American woman who considers Judaism an integral part of her life, I was faced with the challenge of writing a paper on a subject that touched me personally. I thought a paper on rabinas ordained at the Seminario would serve my purpose, but I would realize to my chagrin during my preliminary research for the paper that there was not a lot of material written about the rabinas. Fortunately I personally knew two rabinas from my childhood Rabina ${ }^{106}$ Analía Bortz (currently working in Atlanta), and Rabina Sandra Kochmann (currently in Israel) - and I felt that after contacting them about my idea of researching the issue would be a good way to begin my paper. They expressed their willingness to share their stories with me. My initial success inspired me to seek other rabinas. As I had conversations with one rabina after the other, I was intrigued by the passion they invested into their work. I felt back then that I could let their voices be heard and I made it my goal to meet all the rabinas currently working in Latin America. Rabinas Bortz and Kochmann are not part of this work, but they surely were the catalyst for it. In the

\footnotetext{
${ }^{106}$ In some countries of Latin America, as for example in Argentina and Costa Rica, members of the congregations do not address their rabbis in a formal way, using the word Rabino/a and then their last names, but rather there is a more informal relationship in which they are called by their first names, and sometimes referred to as Rabina/o and their first name. When their names are mentioned in articles or presented in a formal way, they are referred to as Rabino/a followed by their first and last name.
} 
paragraphs that follow, I provide details on the contexts of my encounters with each of the rabinas currently working in the region, my impressions of them, as well as some crucial details of their lives and personal histories. One goal for doing this is to give a human face to these women, who are the hub around which this study spins.

In September 2009 I traveled to Buenos Aires to visit my family and spend the High Holidays with them. High Holidays are considered to be the holidays of Rosh Hashanah (Jewish New Year) and Yom Kippur (Day of Atonement.) ${ }^{107}$ My parents met in a Conservative congregation, Comunidad Bet-El, the one founded by Rabbi Meyer. I have childhood recollections of him. He had moved back to New York when I was still very young. I have vivid memoirs of attending school in Bet-El, being in the youth groups, and Machane Ramah (camp) where I shared Jewish life experiences with other children. Rabino Daniel Goldman, for whom I have deep respect and appreciation, has been the spiritual leader of the congregation for the past twenty years alongside other rabinos. However, for the past four years he has been working with Rabina Silvina Chemen who is the first rabina in the congregation. Despite the fact that I had not yet personally met her, I had seen her leading prayers during High Holiday services. I specifically recall the Erev Yom Kippur of 2009 (the eve of the Day of Atonement) when she stood at the pulpit dressed in a white shirt, white pants, and a white tallit (traditional prayer shawl), and sang alongside the chazan (cantor) Kol Nidre. That night she also delivered the sermon. At the end of the service, people approached her to offer hugs and wish her a Happy New Year, and she engaged in small conversation with almost every

\footnotetext{
${ }^{107}$ Also known as Yamim Noraim. During this holiday, it is customary for families to get together.
} 
person, calling each of them by their first name. I still feel the excitement that shot through me that day when she spoke to me.

Through Rabino Goldman I was able to personally meet Rabina Chemen and interview her. ${ }^{108}$ During our encounter, she was extremely friendly and spoke openly to me about everything. She was born in Buenos Aires in 1962, and at only thirteen years of age she was asked by the rabino of her congregation to prepare twelve-years old girls for their Bat Mitzvah ceremonies. Also, because of her beautiful voice, she was sometimes asked to perform as a cantor during services. Influenced by her mother, a "traditional" teacher of escuelas normales (equivalent to mainstream middle and high school), Rabina Chemen became a teacher as well, focusing on Judaic studies. Because of her knowledge of the Tanakh and of Hebrew, she was sometimes asked to fill in for the rabino of her congregation when he was absent. She recalled that around 1990 she was approached by a bride and groom who asked her to marry them. "Because they loved my tefillah [my prayer]," she said, "and that is how everything started." 109 In the years following that wedding ceremony, she was asked to marry other couples as well, so many, that on the day she weaned her second son, she sat down with her family and told them: "Listen, you have to support me now because I have to study to become a rabina. People call me rabina and I am not one." And it was on that day that the dream of becoming a rabina would finally start to come true, a dream that happened "naturally and without being

\footnotetext{
${ }^{108}$ At that time, I obtained IRB approval to interview Argentine rabinas for a research paper, “Argentine Female Rabbis" for a course I was taking (Latinas and Religion).

${ }^{109}$ Almost all interviews were conducted in Spanish and all translations are my own.
} 
planned." She started her studies at the Seminario Rabínico Latinoamericano and was ordained in 2006. Since then, she has been the rabina of Comunidad Bet-El.

\section{Figure 5: Rabina Silvina Chemen}

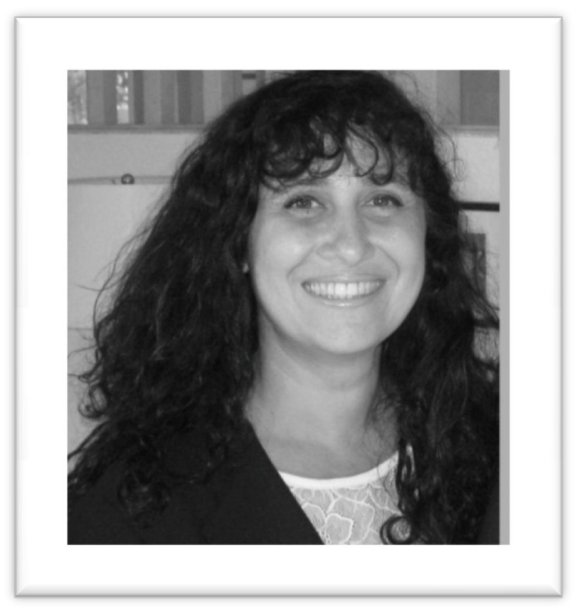

On that same trip in 2009, while conducting research at the Seminario's library, the librarian suggested I meet Margit Baumatz, the first woman to be ordained as rabina, and that I tell her about my research. Rabina Baumatz invited me to her home to personally meet her, a genuinely nice gesture since she did not know me or anything about me. The day I arrived at her house for the interview, the first thing she told me was, "You are lucky, I was able to call Rabina Sarina Vitas and you will meet her too." I was happily surprised; I was meeting the first Latin American woman ordained as rabina and the first rabina to hold pulpit ${ }^{110}$ by herself in Latin America. That day Rabina Baumatz opened the door to her home and to her life.

${ }^{110}$ The term in Latin America for someone who is the sole rabbi of a congregation. 
Rabina Baumatz was born in Breslav, Poland in 1937, place her family would flee a year later to escape the Nazi regime, finding refugee in Buenos Aires, Argentina. Her family was not observant at all, and she defined them as "Germans of Jewish faith. They were not German Jews, but Germans.” She attended a non-Jewish German school in Buenos Aires until she turned fourteen, when her parents told her she needed to have a Judaic education and sent her to Lamrot Hakol congregation in the neighborhood of Vicente Lopez. She became active in the youth movement of the congregation and at age eighteen her father sent her to study at the B'nai B'rith" 111 "because he did not want [her] to go to the university." There she met her husband, a more religious person, and it was then that she started to acquire the knowledge and love for Judaism. She told me how her love of challenges and the little "rebel inside her" pushed her to start studying Torah and Talmud and to become very involved in different educative areas in Lamrot Hakol. Days before a new young rabino came to work there, members of the board of directors approached her and asked her: "Margit, you have been part of this congregation for many years; this person is a newly ordained rabino that has never worked before, and he has never been in a yieke (German) congregation. Why don't you work with him and help him adapt?" And so she did, and became very close and dear to him. It was the same young rabino who approached her one day and asked her, "Why don't you become a rabina?" And so she did. At "fifty something" she entered the Seminario and was to be the first rabina ordained there. She is extremely proud of this fact, as evidenced by a binder she has treasured through the years filled with articles written about her. "Look,"

\footnotetext{
111 Since its foundation in 1930, B'nai B'rith has been dedicated to assisting all Jews in social matters as well as providing courses on different Judaic topics.
} 
she said with a broad smile and a sense of pride while showing it to me, "it was announced all over the world." I flipped the pages and saw hundreds of articles in at least four different languages commemorating that momentous day. It was a long road for her, filled with challenges and difficulties, but as the name of the congregation to which she gave so many years of her life announces - Lamrot Hakol, (Hebrew for in spite of it all) - she did it.

Rabina Sarina Vitas arrived 45 minutes later. A young, energetic woman, she stormed into the house like a hurricane and sat right in front of me. She looked down, took a deep breath and introduced herself. Rabina Vitas told me how tired she was, how she had many things to do, and how much she loves Rabina Baumatz, "It is because of my love for her that I am here today," she said. "I cannot tell her no." While taking her jacket off, she explained to me that she had just arrived a few days earlier from her congregation in Paraná, in the province of Entre Ríos and that she would be returning there a few days later for Succot services. Born in 1970, Rabina Vitas was a member of Comunidad Bet-El where attended school, as well as camp and youth activities. She comes from a Sephardic family, and she described how her formal education collided with the traditions of her home:

For example, for the seder ${ }^{112}$ of Pesach (traditional dinner of Passover night) men would sit together singing and participating, and I always wanted to sing the Ma Nishtanah ${ }^{113}$ or share the things I had learned in

\footnotetext{
112 The word seder means order in Hebrew, meaning that there is a specific order to be followed while reading from the Haggadah, (liturgical book), reciting the blessings, and performing customs and rituals.

${ }^{113}$ This is a song that the youngest child sings during the seder in which four questions are asked to understand why the night of Passover is different than the rest of the nights.
} 
school, but instead I had to sit with the women and help them with the food, becoming [only a] spectator [and not a participant].

In Bet-El she met Rabino Meyer, a very influential figure in her life who told her at one time, "You could be a rabina; you have to take a chance." Rabina Vitas paused, looked at me and said, "So I think I treasured that somewhere in my heart."

Rabina Vitas described everything in her life as a natural process of finishing one thing and starting something else. While working as a youth leader, activities coordinator, and teacher of Talmud Torah (preparing children for the coming of age ceremony) at congregation Bet-Hillel in Buenos Aires, she began studying at Abarbanel (the school of teachers at the Seminario) and also pursued a degree in public relations. She realized that all the choices she had made throughout her life were related to communal and congregational work. She was faithful, religious, and had a love for everything related to teaching. Therefore, it was a "natural decision" for her to begin her rabbinical studies at the Seminario. Her father questioned her decision and warned that once she finished her studies, she would reach a ceiling beyond which she could not advance. He said that she would be a teacher her whole life afterwards, especially after her ordination. She repeated the answer she gave him in a speech she delivered the day of her ordination in 2002; "On top of ceilings we can build too," she said. And this is what she has been doing since, building beyond the ceiling, adding stories to the history of the rabinas. She became the first sole rabina of a congregation in Entre Ríos, and after five years, she moved back to Buenos Aires, where she has been working since February of 2010 in Or Jadash, again, as a sole rabina. 


\section{Figure 6: Rabinas Sarina Vitas and Margit Baumatz}

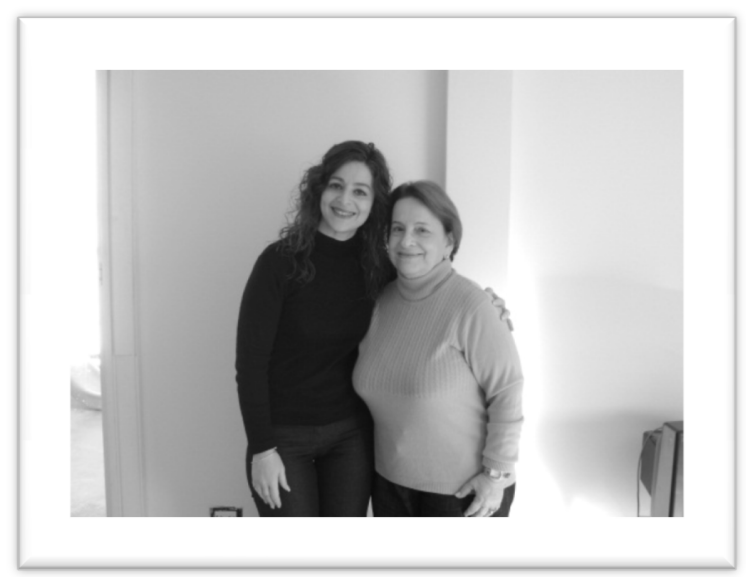

A few months after my trip to Argentina, in December of 2009, I was awarded a Tinker Field Research Grant to conduct fieldwork in Latin America, and I had the opportunity to travel back to some Latin American cities — to San Jose, Costa Rica; Sao Paulo, Brazil; and Buenos Aires, Argentina — to meet all rabinas currently working in the region. ${ }^{114} \mathrm{I}$ traveled to San Jose on June $24^{\text {th }}, 2010$, to meet the rabbis of B'nei Israel congregation, Rabina Daniela Szuster and Rabino Rami Pavolotzky, a married couple from Argentina working in San Jose since 2004. B'nei Israel is the only Conservative congregation in San Jose and counts among its members around 80 families from different countries in Latin America and the United States. Rabino Pavolotzky was born in 1974, and in 1992 began his studies at the Seminario where he met Rabina Szuster. They were married years later, before their ordination in 2003.

${ }^{114}$ After obtaining IRB approval on June $3^{\text {rd }}, 2010$. 
I met Rabina Szuster early the next morning at the congregation. She sat across her desk from me, casually dressed and wearing her kippah. Born in 1976, Rabina Szuster had a Jewish upbringing, attending Jewish schools and participating in youth activities within her congregation, Or Jadash. She recalled the day that two rabbinical students started to work at her congregation and how one, Analía Bortz, ${ }^{115}$ changed her life. After her Bat Mitzvah ceremony she would get together with Analía every Friday evening before Shabbat services and study different subjects such as Kabbalah (Jewish mysticism), the weekly Parashah (the portion of the Torah read that week), or other issues on Judaism. Besides her love of Judaism, she noticed how much she enjoyed a lot of things that a rabbi does - teaching, interacting with people, knowing what is going on in their lives and being able to help them — so she decided to become one, and began her studies in 1995 at the Seminario. After finishing her year of studies in Israel she chose to stay an extra year in order to take courses in Jewish feminism. She was ordained in 2003 and with her husband Rabino Pavolotzky, began searching for a job in Latin America, ${ }^{116}$ a task which proved to be extremely difficult for a woman. Many doors were shut on their faces, until Rabino Pavolotzky had a job offer from Costa Rica. He spoke to the board of congregation B'nei Israel and told them he would love to be their rabino but he also wanted his wife to be the rabina with him, and the board accepted his condition. Rabina Szuster has been working there since 2004, and even though she has hit some bumps along the way, she has accomplished many things. She is currently pursuing a

\footnotetext{
${ }^{115}$ She was the second woman ordained in Latin America, just a few weeks after Rabbi Baumatz.

116 They both told me that they did not want to go back and find a job in Argentina due to the economic crisis and instability that was taking place in Argentina; they could not foresee it as the place to start a family. Therefore they looked at congregations in Latin America, since their primary language was Spanish, and also at a couple in Spain.
} 
Master's degree in women's studies at the University of Costa Rica. I greatly appreciate the hospitality of Rabbis Szuster and Pavolotzky and I was also able to experience a morning Shabbat Service at their congregation, in which Rabino Pavolotzky introduced me and my work to the congregation and honored me with an Aliyah to the Torah (saying the blessing for the Torah reading). Congregants were extremely cordial and approached me after services to share their feelings of having a rabina and on her work.

\section{Figure 7: Rabina Daniela Szuster}

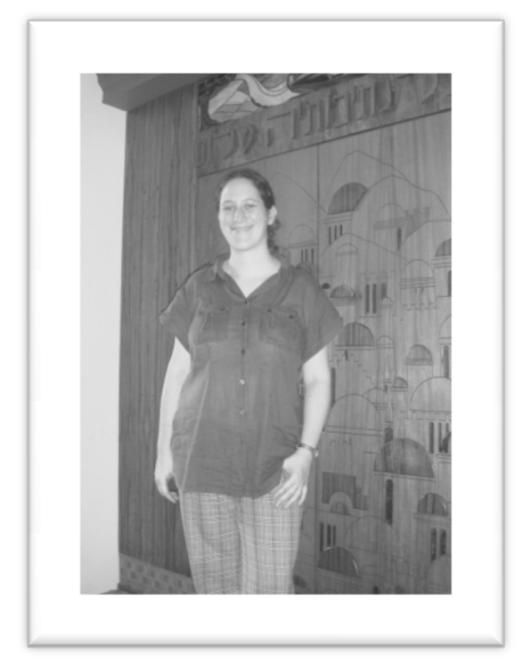

On Monday, July $12^{\text {th }}$ I flew — just for the day — from Buenos Aires to Sao Paulo, Brazil in order to meet Rabina Luciana Pajecki-Lederman from Comunidade Shalom. I arrived at the congregation exactly at the time of the interview but, to my surprise, she was not there and no one had knowledge of our meeting. I sat down waiting for her, my frustration growing; that day was my only opportunity to meet her. She arrived three hours later and informed me she had been at the cemetery performing a burial. I understood that in a rabbi's life, unexpected things happen and she has to be there to serve the needs of the congregants first. 
Rabina Pajecki-Lederman is a petite woman who speaks enthusiastically. She was born in Sao Paulo in 1974, and described her childhood as not religious at all, since her parents were not educated in Judaism and had no interest in attending religious services or celebrating holidays. She explained that Judaism had become socially important to her as a teenager while attending Jewish girls' scout and youth's group activities, but that she had not yet fully committed to it. Later, when she began her undergraduate studies in law, she was the only Jew attending classes with many people from the country who had never had contact with Jews before. This was a life changing moment for her. "I found that I had to explain myself a lot because they had no idea what a Jew was," ${ }^{117}$ she told me. "And then I started to ask myself what defined me as a Jew, what being a Jew meant to me.” During her studies, she began attending activities at C.I.P. (Congregação Liberal Paulista), and ended up working as a youth leader in one of its projects, campo do studio (studies' camp) which had a more religious orientation. She said her work at campo do studio marked the beginning of her career as a rabina. Around 1992, she met a couple from Argentina who started to work at C.I.P., Rabino Adrian Gottfried and his wife Mariana. Through them she learnt that Judaism could be egalitarian, offering the same opportunities to men and women, a fact that encouraged her to become more involved. She told me that after a few years of working in Jewish organizations as a teacher, she realized that she wanted to go to rabbinical school, because, she said, "you really dive into Jewish things [there]; it helps you create a sense of community; it is intense, and so it is a great communal experience." At the time, she was dating the man who would later become her husband, and because he had more opportunities to study in the United

${ }^{117}$ The interviews with Rabina Pajecki-Lederman were conducted in English. 
States, in 1999 she moved with him to New York and started her studies at the Jewish Theological Seminary (JTS). Rabina Pajecki-Lederman received her ordination in 2005 and a few months later, became rabina of Comunidade Shalom, where she has been working since, alongside her mentor, Rabino Gottfried.

\section{Figure 8: Rabina Luciana Pajecki-Lederman and Rabino Adrian Gottfried}

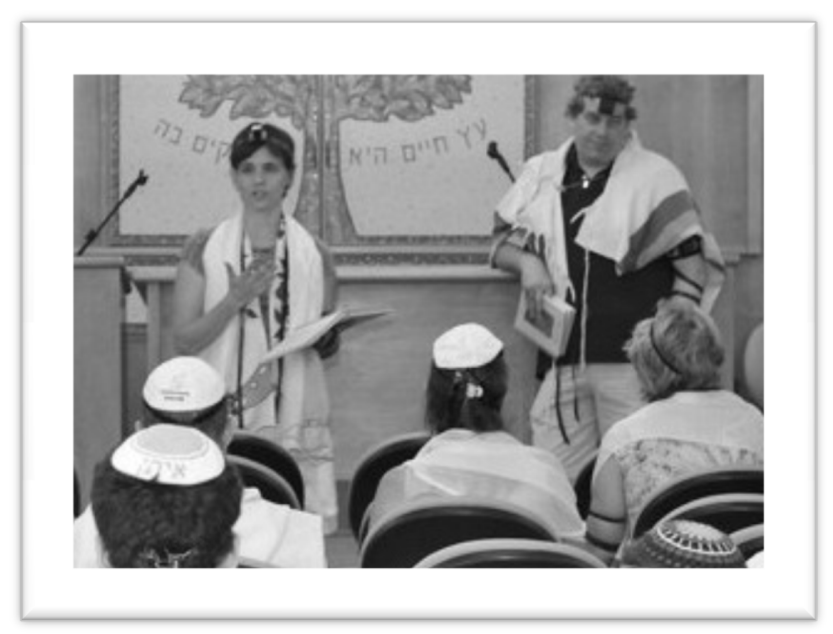

After my return to Buenos Aires, on July $13^{\text {th }}$ I met Rabina Graciela Grynberg from Benei Tikva congregation whose journey to become a rabina began later in her life. Born in La Plata, in the province of Buenos Aires in 1951, Rabina Grynberg loved Judaism from very early in her childhood. Influenced by her Orthodox grandparents, she went to synagogue every Shabbat and the doors of her family's home were open to all during the holidays. But what most influenced her was the attitude of her mother, who did not make any distinctions between her sons and daughters when it came to customs or to attending religious services. Her mother pushed her towards Judaic studies and because of her support, Rabina Grynberg graduated as a morah (teacher). She then married at the "young age of twenty two" and had her first two children before becoming an architect 
(she would have one more child afterwards). For many years she built a successful business as an architect, however, deep inside her, she knew she wanted to become a rabina. She told me that at age sixteen, a friend told her that she would be the first rabina, "because I had a strong feeling for that," she said, "but it was impossible to pursue that here in Argentina at that time." She gave me two main reasons driving her decision to become a rabina. The first dates back to her childhood, when she used to ask her grandfather why Jews did certain things and he always replied, "Just do it." She knew there were reasons, and by studying she would be able to learn them. "Today that I am a rabina, I realize that it was not the only reason why I wanted to become one" she said. "As a rabina, I can follow my Judaism, which I love deeply, and want people to love it the same way, and that is what I emanate. I realized God put me here to do something." For her, that "something" is changing people's lives by touching them in a unique way, and by speaking to them with a special sensitivity. She seemed very much encouraged by the appreciation of her congregation. In 1994, at forty nine years of age, she began her studies at the Seminario, during which she started to work in different areas of Benei Tikva, a Conservative congregation founded by German immigrants and led by Rabino Abraham Skorka. After her ordination in 2002, she continued working at Benei Tikva, however it took her a long time and a lot of hard work to acquire her current position. The congregation was not egalitarian before her arrival, and even after, changes were slow to come. Presently, women are gaining their own space in the synagogue and in liturgy. I could see her "feminine" influence everywhere. There were very modern and fashion-forward kippot (plural of kippah) available for women to wear, with beads and feminine embellishments (she was wearing one like it). And when she took me inside the 
synagogue, she uncovered the doors of the ark holding the Torah scrolls and I saw two beautiful stained glass panels that she told me designed herself.

The same day I met Rabino Skorka, who told me that Rabina Grynberg has been doing a "terriffic" job in the congregation and that they both have a very good relationship. To me, based on what they told me, that relationship is marked by mutual respect and by acknowledging each other's strengths and limitations. Both asserted their great professional and personal bond.

\section{Figure 9: Rabina Graciela Grynberg}

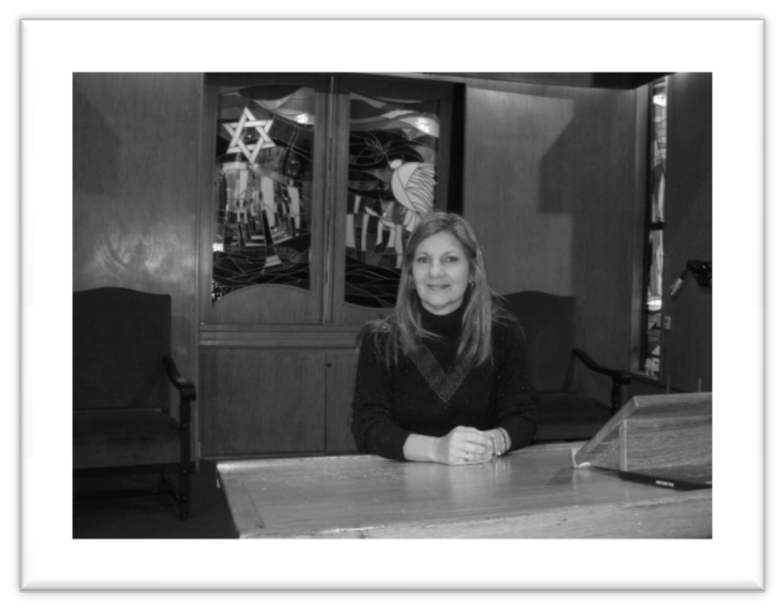

On July $13^{\text {th }}, 2010$ I also met Rabino Alejandro Avruj from NCI-Emanu-El. He received his ordination in 2002 at the Seminario and has been working at this congregation for the past six years. He knows Rabina Karina Finkielsztein since they were teenage kids. He told me how little by little she was accepted by the congregation as the rabina and how hard she worked for it. The next day I met her, a young and invigorating person. Rabina Finkielsztein discussed her childhood shaped by a family in which education and Judaism were valued. Every Saturday she attended Orthodox services with her grandfather, during 
which she sat right next to him, ${ }^{118}$ absorbing every single thing that happened around her. After her Bat Mitzvah ceremony she decided she wanted to learn more, and a rabino gave her classes on how to read from the Torah, on Jewish customs, etc. She stayed with him, learning and participating in services. At age eighteen, she was asked to cover for the rabino when he went on vacations, so for three months she led services, gave speeches, and read from the Torah, performing all of rabino's usual duties. That year, she began her studies in Judaism at the Seminario and in education at the university while working as director of Talmud Torah in the same congregation. Two years later, she was offered a job as director of Or Israel, a small congregation of elderly immigrants, and it was then she realized that she wanted to become a rabina. Recalling her experience in the small congregation she told me, "I did everything there, from the tefilot (prayers), preparing kids for Bar or Bat Mitzvah, reading the Torah etcetera. I was the first woman to hold pulpit as a sole leader in Buenos Aires. That happened around 2001." Rabina Finkielsztein was ordained in 2005. She worked in Or Israel for ten years, helping the congregation grow to 150 families, until she realized she had reached a ceiling and it was time to move elsewhere. In 2006, she accepted a job at NCI-Emanu-El, a much larger congregation. She told me how great it is to work with Rabino Avruj and said they "more or less" divide the work "fifty and fifty," but her job leans more towards education and his towards public relations. Rabina Finkielsztein was extremely nice and proud of her work, not only within the congregation but outside of it, where she participates in interreligious dialogue as well. She asked about my interests, and a few months after our

\footnotetext{
${ }^{118}$ In Orthodox congregation it is customary to sit men and women separately; however, this rule does not apply to small kids. Girls can go to the men's section as well as boys can be at the women's one.
} 
meeting and sent me an invitation to join her and a group of women who were traveling to Israel to study.

Figure 10: Rabina Karina Finkielsztein and Rabino Alejandro Avruj

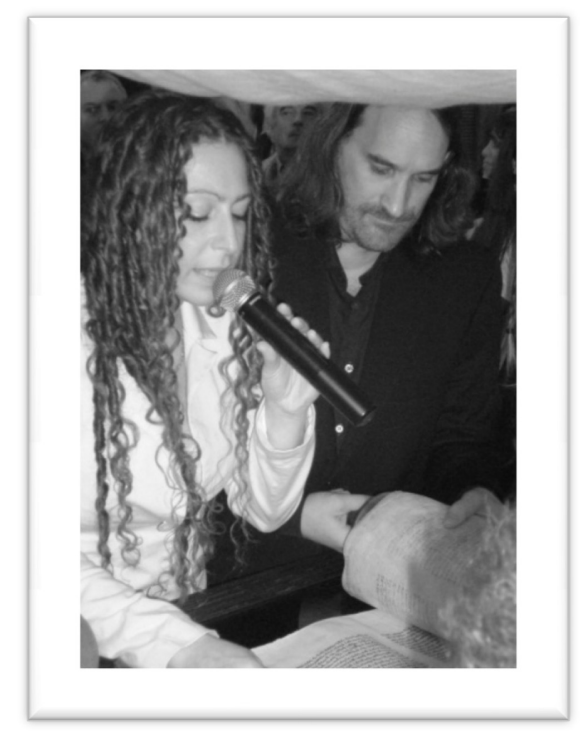

On this same trip to Buenos Aires I met with Rabino Daniel Goldman from Comunidad Bet-El and we talked about Rabina Chemen's work and his own thoughts on the issue of rabinas in the Conservative movement. I was also invited for breakfast to Rabina Vitas' home, where Rabina Baumatz would join us and I could update them on my research. We were able to talk about Rabina Vitas' new job and Rabina Baumatz's retirement, and more about what we all love: Judaism and the issues of women within the movement.

The ethnographic research did not always proceed as smoothly as I would have liked it to. In some cases, some of the personality traits of the people I met were difficult for me to understand. Nonetheless, I cannot deny the passion with which they discussed their stories, their struggles to gain acceptance, the work they perform, and the love they 
feel for Judaism and education. Each of their distinctive stories helps construct a collective Latin American feminine identity within Conservative Judaism, enriching it in a very unique way. Nonetheless, I did not find this group of women homogenous. Each one is driven in a different way; their passion and love for Judaism came at different stages of their lives and impacted them differently. I met seven exemplary women, and in the next chapters I will expand on their lives, their work, and its impact on other people's life. 


\section{Chapter V}

\section{Rabinas and Education}

The seven Latin American rabinas currently working in the region vary in age and ethnic background, nevertheless they all share a love for Jewish education. Many of them did not know when they were that they would be rabinas; although they were sure they wanted to do something that would involve educating communities. I have already highlighted women's general involvement in education within the Conservative movement, and the rabinas are part of this tradition. All of them worked in education, either as teachers or directors of Jewish schools. Before being ordained, all rabinas were already very active in their own congregations, ${ }^{119}$ playing important roles in non-formal education, as well as in social work. Their curiosity and involvement in the Jewish community was a catalyst for their desire to learn more about Jewish tradition and return that knowledge to their congregations in a different way.

Whether influenced by their mothers, other rabbis, rabbinical students, communal and youth experience, or just their love and affinity for the intellectual nurturing of others, these women have all followed an educational track that lead to their ordination as rabinas. Though each rabina has a different story, the common goal of educating othersbe they children, congregants, or members of society in general—is present in all of them. In this chapter I will explore and analyze each of these women's stories, highlighting commonalities, and explaining differences. I will also argue that the

\footnotetext{
${ }^{119}$ Even though Rabina Baumatz is retired, I will be referring to her work before her retirement in 2010 .
} 
Conservative movement, with its emphasis on education, encouraged pedagogy among women and had a large impact on the rabinas.

\section{Their Beginnings}

Rabinas' involvement in Jewish education began at a very young age and at first was mainly non-formal. ${ }^{120}$ In Latin American Conservative Congregations non-formal education is an important way of keeping Judaism alive in children who might not receive a formal Jewish education. ${ }^{121}$ Youth activities and programs in many of the congregations provide a way for Jewish children to not only socialize together, but to gain access to Judaic studies and knowledge they might otherwise not have. Most of the Conservative congregations in Latin America have a youth department which usually provides activities for children ages two through sixteen. After undergoing training, many of the teenagers then become leaders, continuing not only their Jewish socialization but education as well. Almost all congregations have an annual summer camp filled with Judaic observances, studies, and activities. Though these camps differ slightly from congregation to congregation, they are all modeled after Camp Ramah, the first of "what would become a network of movement camps" in the Conservative movement in the

\footnotetext{
${ }^{120}$ According to the encyclopedia of education, "Formal learning takes place as a result of a classroom or related activity structured by a teacher and/or others for the purpose of helping students to achieve specified cognitive, or other, objectives" (Theall and Farrel, 2493). Nonformal education is therefore defined by encyclopedia of informal education as "any organized educational activity outside the established formal system - whether operating separately or as an important feature of some broader activity - that is intended to serve identifiable learning clienteles and learning objectives" (Smith).

${ }^{121}$ In Latin America, Jewish formal education is provided through private schools, and sometimes is very expensive. Many children attend public schools or other types of private schools, such as an English school, therefore lacking a Jewish education.
} 
United States (Nadell 2005, 1962). In their youth, all rabinas participated in, and were influenced by, the youth movements within their own congregations.

Rabina Baumatz's first contact with Jewish education was through her involvement in youth groups at congregation Lamrot Hakol when she was fourteen years old. She told me that the group was just getting started at that time, so she "kind of founded them and [she] became the secretary of the board of the Youth groups." There were no madrichim (leaders) at that time, Rabina Baumatz explained, so the youth were creating their own activities. Those were her beginnings at the congregation that would later become her second home for many years. After furthering her Jewish education through several courses in the B'nai B'rith, in 1976 she became director of Talmud Torah in Lamrot Hakol. Talmud Torah, translated as the teaching of the Torah, is a required course for boys and girls preparing for their bar or bat mitzvah (coming of age) ceremonies. Basically, the students receive a condensed course in Judaic topics and learn about Friday night and Saturday morning services and prayers. They also learn how to read the portion of the Torah that belongs to their ceremony's date. ${ }^{122}$ The courses usually last a year, but may vary according to the congregation and the child.

Rabina Grynberg shared with me how her mother pushed her to study Hebrew and Judaism while she was a teenager and then suggested she pursue a degree as a morah (teacher). As a young teenager, Rabina Grynberg was also a madricha (youth leader) leading activities in non-formal education. Rabina Vitas was likewise extremely involved

\footnotetext{
${ }^{122}$ Usually the children who do not know how to read Hebrew have to begin the course earlier and learn to read it.
} 
in communal life from a young age. As a teenager in Comunidad Bet-El, she became a madricha and then shared her Judaic knowledge while participating in youth groups. She recalls her life as a teenager outside school as revolving "around congregational activities: morah of Talmud Torah, madricha, director of this-and-that, etc. Everything related to non-formal education." Wanting to strengthen her congregational and institutional skills, she began her studies in education at Abarbanel, the Jewish education institute at the Seminario.

Rabina Pajecki-Lederman grew closer to Judaism as a teenager when she began participating in youth groups. Around the age of twenty she was asked to become an assistant teacher in CIP (Congregação Israelita Paulista), where Rabino Gottfried ${ }^{123}$ and his wife Mariana were working. She did not have any formal training as teacher, but because her knowledge of Judaism had been reinforced by non-formal education throughout her teenage years, she was asked to assist formally-trained teachers, "older women [who were equipped with the knowledge] but needed some new ways, so they [could] infuse their classes with more modern ideas." When Rabino Gottfried and his wife Mariana went to work in Comunidade Shalom, Rabina Pajecki-Lederman was asked if she wanted to be the Jewish Education Coordinator of the small day school they were starting at the congregation. She joked that she was "coordinating [herself], because it was [her] and a secretary," but admitted she learned a lot. She was mainly in charge of the bar and bat mitzvah program training, preparing children for their upcoming ceremonies.

\footnotetext{
${ }^{123}$ Argentine, born and trained at the Seminario Rabínico Latinoamericano, currently works in
} Comunidade Shalom and was Rabina Luciana's mentor. 
The cases of Rabinas Chemen, Szuster, and Finkielsztein differ from the others in that their roles as educators began earlier on in their lives. Rabina Chemen told me that she was asked by the rabino of her congregation to teach in Talmud Torah at the age of thirteen. "He saw something in me" she said, "and I was teaching my friends who were only a year younger." Rabinas Szuster and Finkielsztein's bat mitzvah ceremonies were turning points in their lives. Captivated by Judaism and its teachings, they both decided to continue studying, one-on-one, with the teachers who had prepared them for their ceremonies. Rabina Szuster studied subjects ranging from Kabbalah to Parashat HaShavuah (weekly Torah reading). Rabina Szuster always enjoyed teaching and told me that from a very young age, she loved helping her classmates in Judaic studies. In her later teenage years she became a Talmud Torah teacher in Or Jadash, the congregation where she was raised. She also studied psychology as an additional tool to help her with education and teaching.

Rabina Finkielsztein learned Judaic customs and how to read Torah, among other topics, from the rabino at Bet Am, the congregation where she had her bat mitzvah. She said she always knew she would pursue a degree in education —leaning towards Judaic studies - and in her late-teenage years she become a director of Talmud Torah in Bet Am. She thought that "something happened to [her] in [her] teenage years that helped [her] get closer to Jewish identity and education." She began her studies at the Seminario to become a teacher, realizing that many of her peers were largely involved in non-formal education. She also told me how many of those peers went on to become rabinos, 
connecting the non-formal education in Judaism to the rabbinical career. While studying at the Seminario she was also pursuing an academic degree in education.

Rabina Chemen also had a love for formal education at an early age, which she "nursed" from her mother who was a teacher. When she finished secondary school she started her teacher's training focusing on Judaism, specifically studying Hebrew and Tanakh, while still teaching in Talmud Torah at her synagogue. When she was "very young" she became the principal of a Jewish secondary school. She told me her personal traits might have helped her land that job, as she described herself as "always [a] very driven person."

The proclivity for non-formal education and congregational work was present in all these women from a young age. Probably the emphasis placed on non-formal education within the Conservative movement, carried out through youth groups, influenced them greatly. But for these women getting involved in institutional work it was more than a social cause, they did it because they had a special love for education. For some, it began as admiration for the work of someone they considered a great example in their lives; for others it was innate ability, recognized and actualized by the incentive of another person. No matter how it started, the love for education was, for all of them, what propelled them to become rabinas.

\section{Educational Work as Rabinas}

A rabbi is, as rabina Szuster told me, "a mix of a guide and teacher." A rabbi's actions are an example to follow; a rabbi's teachings are life lessons. Many of the rabinas were 
immensely influenced by other rabbis, and their work is now influencing others. All of the rabinas are (or were) in charge of different areas of education in their congregations. While all of them teach different adult classes or courses throughout the year, their main duty is the education of children, whether overseeing the Judaic programs of their congregations' schools or supervising Talmud Torah. Thus, the rabinas become role models for children who see rabinas as the norm. Rabina Chemen told me that "the younger generations, like the 650 children who currently attend the congregation's school know that [she is] the rabina and have no problems with that." Rabina Szuster shared an anecdote of a woman rabbi in the United States who was replaced by a male rabbi when she left her congregation. A child in the congregation, upon meeting the new rabbi said, "What, a man?! I thought rabbis were women." These women are a great influential force on younger generations and through their teachings they instill their love of Judaism in others while showing them that women can also do a great job as rabbis.

Their daily educational work set an example. Rabina Baumatz gave many courses to adults and participated in interreligious dialogue while she was working at Lamrot Hakol. For over twenty-six years she was responsible for education at her congregation, either teaching or supervising. Rabina Vitas is also extremely involved in education. At her current congregation, Or Jadash, she oversees not only the non-formal education programs of Talmud Torah and youth groups, but the Jewish program at the congregation's school as well. She told me that beyond educating children, she finds herself educating their parents as well, because many are still not used to an egalitarian congregation and believe that certain roles are not common for women. For example, she 
told me that many mothers request a meeting with her because they do not understand how a rabina is able to perform their children's bar or bat mitzvah ceremonies. Even though she gives them the halakhic explanations of why she is allowed, most of the times, they still prefer the "right ways" of the orthodox synagogue.

Rabina Pajecki-Lederman is in charge of everything that has to do with education in Comunidade Shalom, working with "curricula, youth, developing new programs, and teaching." She remarked that because she is a rabina she "get[s] to connect with people in a different way." She feels totally responsible for Jewish education as a rabina, and said it would be selfish to not transmit the knowledge she has. Rabina Chemen is also extremely involved in overseeing the formal education of the school in Comunidad Bet-El, as well as the non-formal education through youth groups and Talmud Torah. She teaches courses and classes for adults, and has also published several books. Education is extremely important to her.

Rabina Szuster shares the responsibility of education in her congregation with her husband, Rabino Pavolotzky. Together they teach children in day school (Rabina Szuster is in charge of the "small children" on Tuesdays and Rabino Pavolotzky of the "big children" on Wednesdays), teach a course for adult members, and prepare children for bar or bat mitzvah. Outside the Jewish community, in Costa Rica, Rabina Szuster has also taught courses in topics from women and Judaism to Kabbalah and Jewish mysticism. For Rabina Szuster and Rabino Pavolotzky, there is no fine line defining congregational roles. Since they are a couple, they truly share responsibilities in both, their home and congregation. 
Rabina Finkielsztein told me, "Education is the part of the rabbinical career that I like the most. I think speech has a limited impact, it can stir the emotions and reach inside of you, but if you do not do something afterwards to continue, it ends there." She told me that "Ceremonies are an excuse to get inside people's homes and educate them." This defines her role as an educator: the knowledge to explain the underlying meanings and reasons behind ceremonies and rituals. Both she and Rabino Avruj told me that she is in charge of all that has to do with education; she oversees Talmud Torah, adult study groups, and the school's Judaic program. They are both involved with youth groups, but Rabina Finkielsztein is the one responsible for training the madrichim and putting together the educational program. Although both of them teach various classes and courses, Rabino Avruj remarked that "she [Rabina Finkielsztein] is the one coordinating everything. She is excellent, not only because she knows what she teaches, but because her didactics are excellent." It was totally clear to me after meeting both of them, that their respective roles were well defined, and that Rabina Finkielsztein was not only in charge, but respected and appreciated as an educator.

Rabina Grynberg is also extremely involved in education within her congregation, though it took her a long time to achieve her present position. Her congregation was not egalitarian so introducing a rabina was an educational task in itself. She found herself explaining and justifying her actions as rabina to members of the congregation that look at her with some disapproval. After many years of hard work, she became accepted and respected by congregants. She is in charge of children's education, mainly in Talmud Torah. She plans special activities not only involving the children but also their 
families. ${ }^{124}$ In her words, "I always tell them that a rabbi is a moreh (teacher), so I always teach them something and finish with a story." She also took under her control the education of brides and grooms, teaching them how to keep a Jewish house in the twentyfirst century. Rabina Grynberg's personal touch is present in all her teachings.

\section{The Importance of Women and Education}

One of the milestones in the equalization of women within the Conservative movement was the evolution of women's place in society. Nadell tells us that for the Jewish Theological Seminary (JTS), the revision of women's place within the movement "meant creating spaces for educating Jewish womanhood.” The Women's Institute of Jewish studies was created in the early 1930s to prepare participants "for leadership in women's work" (Nadell 1998, 177). The importance placed by the movement on education is great; furthermore, with the creation of the Women's Institute, the idea of women's leadership in education was not only recognized but validated and accepted by Conservative leadership. Nonetheless, a separate institute to train only women underscored gender differentiation. For what type of leadership were women being trained? Was it meant to be leadership of women for women only?

In 1909 the Teachers Institute was founded by the JTS in order to train teachers for weekday Hebrew schools, and its academic department attracted those seeking a “college for advanced Jewish studies." Its courses were extremely advanced, and

\footnotetext{
${ }^{124}$ For example she started an activity where grandparents share their legacy. They participate by telling their grandchildren where they come from and if they had a bar or bat mitzvah ceremony themselves. They also have to bring a significant present for their grandchildren. Another activity is the Sabbath dinner in which she gives each family a book explaining how to have a Sabbath dinner.
} 
admission required that applicants be able to read Biblical Hebrew, converse in Modern Hebrew, and display a broad understanding of Jewish history. As mentioned in chapter II, between World War I and II, whenever a woman sought to get into the JTS to study, she was referred to its Teachers Institute instead (Nadell 1998, 179-180). The Institute became an incredible success among women who wanted to study in an egalitarian environment, and by June of 1935 it had graduated 289 women and 202 men. Most of the graduates would later teach in religious schools. But in 1957, Gladys Citrin, a young woman with an extensive Hebrew and Judaic education, sought admission to the JTS as a means of becoming a "religious and cultural leader of [her] people" (Nadell 1998, 185). The president of the JTS at the time, Louis Finkelstein, responded:

There is no reason why you or any other Jewish girl who so desires, should not devote her time to intensive studies of Judaism. However, in the Jewish tradition, the place of women in religion is to be high priestesses in the sanctuary of their home and we want them to be good wives and good mothers in Israel [...] I would therefore encourage you in any way to continue your studies. Perhaps you would come to our Teachers Institute and become a teacher. (Nadell 1998, 185-186).

There is no doubt that women were absolutely capable of learning and teaching, so why were they not allowed to teach the congregation as rabbis? It took many years for women in the Conservative movement to receive ordinations; nevertheless, many women were able to take the same courses as male rabbinical students in the JTS, but without obtaining ordination. Recognition of women's capacity to teach Jewish tradition and values to children in schools was a way of validating their leadership, initiative, and capacity to set and be examples. Furthermore, since education is a vital role of rabbis, barriers against women's ordination can only be understood as prejudice and tradition. 
The Seminario Rabínico Latinoamericano also has a teachers institute called Abarbanel. It has trained many women and men in Judaic studies; however the majority of graduates who go on to pursue a teaching career are women. The reason many men have graduated from Abarbanel, is that its courses are prerequisites for future rabbinical studies. The story and pattern of the Conservative movement in the United States is repeated in Latin America: women are allowed and encouraged to become teachers, while men have to become teachers only to later on be ordained as rabinos. This shows the importance of education and teaching in a rabbi's job.

The case of Rabina Baumatz, the first woman to be ordained, proves that Latin American society was still not ready to accept a woman in a religious leadership role no matter how well prepared and educated she was. Rabina Baumatz was encouraged by a fellow rabino to study and become one herself, and so she did. She remembers at the beginning of her studies at the Seminario that people were not sure what to think about her or Analía Bortz, who was also a rabbinical student. Nobody thought back then that she would complete her studies. Nevertheless her peers supported her throughout her studies, as she told me, "Imagine, they were all my daughters age!” Everybody was extremely reassuring; she was even allowed to complete her studies in Israel in one month instead of a year. But as she recalls, on the day of her beit din (final examination) in 1994, rabinos boycotted her and some of the members of the exam tribunal did not show up. This devastated her. She told me, "I could not stop crying." In spite of the fact that many women rabbis had been ordained in the United States since 1985, it appeared the Conservative leadership in Latin America was not yet ready for a rabina. A week 
later, the tribunal met again and she was able to take her final exam and receive her ordination. I believe the fact that she was already fifty-years-old earned her the respect of other students and teachers. Her knowledge and experience working for over twenty-five years in her congregation as Talmud Torah coordinator among other duties, helped her as well. She was already assisting the rabino of her congregation and performing some of his duties. In her heart, she was already a rabina, and so she was in the eyes of some others.

Rabinas Finkielsztein and Chemen were also performing the duties of a rabbi before their ordinations. Both of them remarked how the Jewish education they received and their own love for educating others helped them. Rabina Finkielsztein was asked by her congregants to lead the congregation. They accepted her performing the duties of a rabbi; even though she did not have her ordination, she had passion and love for education. Rabina Grynberg was asked by the board of directors to work in Benei Tikva "to make changes" while she was studying to be a rabina. And Rabina Vitas was always involved in the non-formal education and guidance of children in Beit Hillel while studying at the Seminario.

Rabina Szuster told me something that reinforced my belief in the importance of education in the rabbinate:

I do believe that in the rabbinical career there are some trends and duties that have to do with the traditional roles of women. For example, the fact that one has to help and assist people and teach. In general, at school, the majority of teachers are women, not men. But for a long time, the place of the rabbi was more prestigious and belonged just to men, so it was harder for women to access that place. 
Within the Conservative movement in Latin America there is still the struggle between tradition and adaptation. The traditional role of women in Judaism and in Latin American society still persists in peoples' minds. Changes take time. Nevertheless, I believe that the emphasis on that traditional role is also an advantage for these women who can use their skills and knowledge to educate children as well as adult members of their congregations. Like mothers, they are given the task of perpetuating tradition and serving as role models to younger generations. The issue in place in Latin America is different, because organizations are still gendered and the man is still the norm for a leadership position in both, religion and local culture.

All rabinas were influenced by the Judaic education they received at a very young age, whether from their families or congregations. Their lives were touched by experiences that sooner or later led them to rabbinical school. But they all have the same objective: to share with and teach others the love and passion they have for Judaism. In doing so, they perform different tasks and activities. Education is an integral part of their work, but they perform other duties as well, which I will introduce in the following chapter. 


\section{Chapter VI}

\section{Rabinas: Public Roles and Private Lives}

As I have already demonstrated in the prior chapter, education has been critical in the work and lives of the rabinas; however, they also perform many other tasks in their congregations, the Jewish community, and outside it, which I will be exploring in this chapter. The rabinas place a great importance on their families and this impacts their work. As noted in chapter I, for some feminists, motherhood acts as a constraint against women's equality and advancement in the professional field, but as I spoke to the rabinas, I realized that this understanding was not shared by all of the rabinas. In contrast, most of them told me that motherhood makes them better rabinas and enhances their every-day work. In the case of the rabinas who have a rabino partner in their congregation, I will also explore how that relationship with the rabino influences their work; I maintain throughout my work that the division of tasks within the congregation is based on that relationship. Moreover, the stereotypes of women rooted in Latin American culture and society are also influential, feeding into, what I believe, are gender-based divisions of tasks. In order to better illustrate this fact, I will end this chapter with the views of rabinos and feelings towards the rabinas they work with.

\section{Rabinas’ Ritual Practices}

As noted in chapter II, most Conservative synagogues worldwide are egalitarian, providing women with the same rights as men. Still, in Latin America, there are a few congregations that do not give women the same rights. For example, while some 
congregations allow girls to bless the Torah and read from it during their Bat Mitzvah ceremonies, after this single time, women never go to the pulpit and Torah again, ${ }^{125}$ not because they do not want to, but because is not a common practice within the congregation. In Peru, Rabina Grynberg visited a Conservative congregation where it is not customary for women to go to the pulpit and she became the first woman to preach in a Saturday morning service. She told me it was an extremely hard experience, because her actions were not well received by all. However, many members of the congregation did surprise her with positive feedback on the speech she delivered on women and Judaism. Rabina Szuster told me that there is a chazanit (female cantor) in an "egalitarian congregation in Panama," but the same congregation says that "they would never hire a rabina because they cannot see a woman in a role that traditionally belongs to men." Nevertheless, despite a few exceptions, the majority of Conservative congregations in Latin America are egalitarian, and women participate as equally as men.

In the case of Latin American rabinas, nowadays the congregations they currently work at are egalitarian. Women bless and read from the Torah, participate in ceremonies alongside men, and count for minyan. ${ }^{126}$ One of the milestones in women's equalization is the right to wear tallit (prayer shawl), kippah, and tefillin (phylacteries), however, not all rabinas share the same views on this issue.

\footnotetext{
${ }^{125}$ This fact was shared by Rabinas Grynberg, Szuster, and Vitas with me during our interviews.

${ }^{126}$ Rabina Grynberg told me that at the beginning, when they started to count women for minyan in her congregation, some men would joke, saying "ok, three women count as one men." This anecdote illustrates her struggle; even when women were counted for minyan, they still did not count as much as men and the inequality was considered a joke.
} 
The day I met Rabina Szuster, she entered the building of the congregation already wearing a kippah. She wears the kippah as "a Jewish symbol, in order to know that God is above us." She believes it is important for both, men and women to wear it as a sign of respect, and remarked that it is neither a masculine nor feminine symbol; nevertheless it is seen as masculine only because women have not worn it in the past. "Wearing a kippah," she explained, "is not a mitzvah [requirement], but a custom, therefore women are allowed to wear it." She also wears tallit and tefillin when required in the synagogue.

Rabina Baumatz told me that after her ordination she was not able to lead services in her congregation because of conflicts with the rabino. Nevertheless, she was able to introduce some changes. "I started to use kippah, tallit, and tefillin," she said, "and the congregation was outstanding in their support. I was the first rabina to be ordained and I was able to introduce big changes in a yieke ${ }^{127}$ (German) congregation, and that was great." Rabina Vitas also wears tallit and kippah while at the synagogue and places that require her to cover her head, however, she did not mention anything about laying on tefillin. Rabina Finkielsztein told me she started to wear tallit after her grandfather passed away. She recalled:

While my grandfather was alive I did not wear tallit. The day he passed I wore it, maybe out of respect for him. He loved listening to me read Torah, but I do not think he would have understood seeing me wearing a tallit. So I told myself that I was not going to do anything to bother him. Since he passed, I have been wearing tallit.

${ }^{127}$ Yieke congregations are characterized by a rigid structure and are not too prone to changes. 
She wears tallit when required in ceremonies or places she visits. She does not wear a kippah, but she puts on tefillin every morning because it is the mitzvah with which she begins the day. She understands that this particular mitzvah is "elective" for women; the Shulchan Aruch ${ }^{128}$ says that women are exempt from it, but can assume it if they want. She told me that "[laying on tefillin] each morning is the beginning, is binding the head with the heart and with the possibilities of creating."

Rabina Pajecki-Lederman told me that she wears tefillin for various reasons:

According to Jewish tradition, women are exempted but not forbidden from laying tefillin, which means that if they want, they can. Furthermore, in the Conservative Movement, laying tefillin is a requirement for entering rabbinical school, at least at JTS, because they understand that if women are going to lead people in this mitzvah, they need to take the mitzvah upon themselves. For me personally, tefillin enhance my kavanah, my intention and my focus, in prayers.

She also told me that b'not mitzvah (plural for bat mitzvah) are not required to lay tefillin, but only to wear tallit for the purpose of reading Torah. "We teach girls about this mitzvah," she said, "and how to perform it, but let them decide whether they want or not to take it upon themselves. The same thing with older women; some wear tefillin but most do not, since it is still a male reference for both." She explained to me that wearing tallit is different "since it has gained a feminine look."

Rabina Grynberg told me that she wears tallit but does not lay on tefillin; "that is something [she] has to deal with." She told me she always jokes that if the leather strings were pink or any bright color she would lay them on. She explained that the mitzvah of tefillin is time-bound and therefore not mandatory for women. "The issue is," she

\footnotetext{
${ }^{128}$ A code of Jewish law written by Rabbi Yosef Karo in the sixteenth century.
} 
continued, "that if I lay them on once, I would have to do it all the time afterwards, and since I am not sure if I am ready to commit to that, I do not do it. I am not sure why, I should start doing it [...] I think it will not be long until I start.” When I inquired about her wearing tallit, she told me:

Everything was a process in my life. A long time ago, I was in Bet-El when Marshall [Rabbi Meyer] was the rabino, and the night of Rosh Hashanah [New Year] he said that the next day everybody had to wear a tallit. Since there were not enough [tallit] in the congregation, congregants had to bring their own, including women. I looked at my husband and I told myself, 'this is my opportunity.' But the issue was how to buy a tallit the night of Rosh Hashanah. My dad passed away outside the country and we were not able to bury him with his tallit, so the first tallit I wore was his. I felt my dad was hugging me with all his love; I even get emotional telling you this today. So, since that day I started to wear it. My husband bought me one for a wedding anniversary, a beautiful present. When I started working here I did not wear it because no women used it. Until I told myself that if I was going to be the rabina here, I had to wear it, and nobody said anything. Nowadays, when women go to the Torah, I put a tallit on them. We do not force anybody to wear it.

In regards to wearing kippah, she said that one day a member of the congregation told her: "Graciela, you are a rabina; you have to wear a kippah." She said she feels like that person "had pushed her". This encouragement by an observer and her own desire, was all she needed to start wearing it. She wears a kippah "whenever necessary, in the synagogue, cemetery, and etcetera. My kippot (plural) are all feminine," she said. "I have all the colors and members of the congregation wear them too."

Rabina Chemen explained to me that besides being a role model in her congregation, she also has to respect the feelings of congregants and dress in a manner that reflects them. She does not wear a kippah because "women of [her] congregation do not wear kippah, and [she] is not going to dress like what they are not and be different. 
[She] does not dress as a man in order to achieve a rabbinical place, and this is what women value." She does not lay on tefillin because it is not a mandatory mitzvah for women. She said, "If I do not have that mitzvah [upon me], why would I assume it? It is said that one needs to search the most practical way of living Judaism." She does wear a tallit when necessary, but her opinion is that its design does not matter. Rabino Goldman reiterated this notion when he told me:

There are women who use a kippah that is feminine. Silvina does not use a kippah. She uses tallit, but the same one I use, not a feminine one. I think this paradigmatic thing - women wearing a kippah, which is not a kippah but is a feminine symbol - I insist, is not good. If you are going to use kippah, it is all right, but why a feminine one? The kippah that [women] wear, I should be able to use it too, not as an accessory, but as a ritual element. There is no need for creating this symbol from a toxic feminist place, because it is not right. Women who want to use tefillin do it, and if you use it once it is not as if you have to use it every day. Do it as the men, they do not use them every day.

Since Judaism has been traditionally dominated by men, and since the role of men in liturgy and prayers has been central while women were not even considered, symbols such as the tallit and kippah are associated with men. Except for Rabina Chemen, all rabinas feel a need to feminize these symbols in order to make them their own, and something they can appropriate as women. Rabina Chemen, on the other hand, continues to perceive the kippah as a men's symbol, and refuses to "dress like a man" in order to be a rabina. She is a rabina from her "feminine" side and does not feel the need to reappropriate a symbol that is clearly masculine in her opinion. She generally leads by example, in this case, women of her congregation become the example she must follow in order for her to lead. 
The issue of tefillin is still unclear for some of the rabinas, perhaps because it is hard to assume mitzvoth that are not imposed on them. They understand that when they lay them on once, they should do it all the time, but based on the comments of Rabino Goldman, it also seems to me that this practice is not followed by all men in the movement either. I believe these women feel that they are constantly being scrutinized; therefore they feel a need to follow every practice the way it is supposed to be. It is a clear double standard: on one hand, men (including) rabinos do not practice the custom as it is "supposed to be" practiced all the time, and on the other hand, rabinas feel that if they do not follow the custom appropriately, they will be harshly judged. Whether they lay on tefillin or not, all rabinas agree that they are setting examples for women congregants. The disagreement on whether these symbols should be "feminized" also highlights the different perspectives, not only among rabinas, but between congregations in general, making the Conservative Movement in Latin America diverse and complex.

In her study of two Conservative synagogues in the 1990s, Riv-Ellen Prell found that the ambivalence between "achieving equality and celebrating differences permeates synagogue practice... When a woman chose to wear a tallit, it became a personal statement and a ritual act that more consciously linked her to Jewish practice" (Rubin Schwartz, 171). The rabinas feel that wearing a tallit is not a personal statement, but a way of being equal to men in the synagogue. However, the need some rabinas feel to 'feminize' symbols and practices, suggests that while they want to be equal with men, they also want to distinguish themselves as more feminine than men. 


\section{Rabinas in the Synagogue}

All but one of the rabinas participate in the synagogue daily, leading services, reading from the Torah, and preaching from the pulpit. However, it took almost five years after Rabina Baumatz's ordination for the rabino in Lamrot Hakol to let her participate during services. Moreover, the first time she did, it was because the rabino had a personal issue and was unable to lead the service of Erev Yom Kippur (eve of the Day of Atonement.) After that day "every once in a while he would let [her] participate in services." But would however come to every service and seat among congregants. She told me that she "was never the rabina of the congregation, but it did not bother [her] because [she] did not study to be a 'rabbi of the pulpit'."

It took Rabina Finkielsztein some time to acquire her current degree of participation in services. Rabino Avruj told me:

Even though [NCI-Emanu-El] is an egalitarian congregation, at the beginning, it was difficult having her as a rabina and it was a slow process. When she first started to work here, she would not go to the pulpit; then she started going once a month, and then more often. Today we share almost everything.

Rabina Finkielsztein never mentioned this to me. Since she told me that before being ordained as a rabina she was already leading a congregation and performing rabbinical tasks, the fact that she did not fully participate during services when she began working in NCI-Emanu-El seems unrelated to her capabilities as rabina. Furthermore, Rabino Avruj told me that he personally knew Rabina Finkielsztein since they were both teenagers and that they had worked together at a congregation before, so he was also 
aware of her knowledge. The issue seems to be that since she was a woman fulfilling a rabbinical role, she needed some time to be tested and accepted by the congregation as such. Her credibility was already established, yet she still needed to prove she was capable.

Rabina Grynberg had extremely hard time gaining acceptance by all members of the congregation. When she first was ordained and began working in Benei Tikva, there were some who asked, "What is she doing here?" In the beginning, she was not at the pulpit but seated with the rest of the congregants observing and accompanying Rabino Skorka in all activities, in order to learn what things were done and how. Then she began giving the final blessing at the end of Friday night services. She told me that, at the beginning, she thought "People felt that as long as [she] did not bother and did not do a lot of things, it was all right." But there was one event that was extremely hard for her, as she recounted:

On a Saturday morning service I went with another woman to the Torah for the first time. Girls were already going up to the Torah on their bat mitzvah ceremonies, but that was it. We recited the Torah blessing, something that has not been done before. A man who used to be baal koreh (person in charge of reading from the Torah) in the congregation of ninety-something years old, stood up with his wife and left. I did not feel bad; I felt terrible. After that happened, I searched for his address and went to his home. At first he did not let me in, but finally he did. I told him that, first, I was not doing anything against Jewish law. Second, I told him that if somebody has to leave the congregation, it would have to be me, not him, because he has been a member for over fifty years. 'If you want', I said, 'I will leave, but I ask you to please come next Shabbat.' Nowadays we are friends and he keeps attending our services. I did not realize the resistance I faced in the synagogue. Maybe if I would have, I would not have stayed. I was so excited with the opportunity I had that I did not pay attention to that. 
A theme that runs through the narratives of the rabinas, except Rabina Finkielsztein, is that they were already part of their congregations while in rabbinical school. Their work was already known there and they had already established a rapport with congregants and they were familiar with the common practices and the dynamics within the congregations. Once they received their ordination they faced a new challenge: acceptance as rabinas. There is no doubt about their knowledge of congregational practices; however, breaking through the model of the rabino as leader of the congregations was extremely difficult. The model of rabino as a leader had been the only one known to congregants in the past, and since the phenomenon of rabinas was still fresh, acceptance was a process. In some cases, like with Rabina Baumatz, there was an issue with a jealous rabino who believed that by not allowing her to participate during services he would be able to monopolize congregational leadership. Obviously he failed, because Rabina Baumatz became a leader anyway, and not from the pulpit, but by working hand-in-hand with congregants. The link between male authority and leadership was prevalent in all congregations, and it took rabinas time and effort to gain recognition as congregational leaders in their own right.

\section{Rabinas and their Participation in Ceremonies}

Although rabinas are allowed to perform all ceremonies rabinos perform, I noted to my surprise that they did not carry out certain ceremonies, especially weddings. Rabina Szuster is the only one who regularly performs weddings, which she does alongside her husband Rabino Pavolotzky in Costa Rica, and nobody questions that. Rabina Baumatz did not perform weddings while working in Lamrot Hakol, and the other rabinas told me 
that the rabinos of their congregations perform the weddings, unless the bride and groom request the rabina instead. Jewish weddings do not have to be performed by a rabbi, the only requirement in Conservative Halakhah is that the Ketubbah (marriage contract) be signed by the bride, groom, and two witnesses. Traditionally, women were not allowed to act as witnesses; however, the Conservative movement created a responsum allowing women witnesses.

The case of Rabina Vitas is particular, since she has been the sole rabina in the last two congregations she worked for. She told me that she does perform weddings, but that she finds herself explaining the " $\mathrm{ABC}$ of women performing weddings" to almost all the couples who feel hesitant about a woman performing the ceremony. Rabina PajeckiLederman told me that she performs the ceremony only if Rabino Gottfried is not available, since he is the congregation's main rabbi.

Rabina Chemen told me:

Brides and grooms are little-by-little requesting that I marry them. I do not do anything to get more people to ask me. Dani [Rabino Goldman] performs ninety percent of the wedding ceremonies. There is no mental representation of women performing weddings; I do not want to enter through a window if I can enter through the main door when the conditions are ready for me to do so.

This is an interesting fact about Rabina Chemen, considering she told me that before she even entered rabbinical school a couple had asked her to marry them. When she does perform the ceremonies, she does not sign the Ketubbah because she wants the wedding to be kosher in all denominations, and since there are people who still do not accept 
women as witnesses, ${ }^{129}$ she would rather refrain from signing and keep the document “legal.” Rabina Grynberg told me that Rabino Skorka also performs over ninety percent of the wedding ceremonies in their congregation. "We do not give the option here," she said. "If a bride wants me to do it, I would do it with no problems." Rabina Finkielsztein told me:

Only Ale [Rabino Avruj] performs weddings, because I think Ale is a very charismatic person, so when the bride and groom come here it is because they like the way he performs the ceremony. I have performed several, but not many people had the possibility of getting to see me perform them.

When I asked Rabino Avruj why was he the only one performing wedding ceremonies he told me: "We have not pushed the issue yet, I do not know why, maybe this could be a self-critique. But I feel there is certain apprehension with the fact that we need to accept her role as also being able to officiate weddings. We have to work on that." He paused, as if he needed to reflect on what he had just told me, and said, "Maybe it has to do with the place each of us has. She is more reticent to be part of the ritualistic side of Judaism, she is much better in the educational side of it, so I think it is better for her to focus on that area. That is why I am more in charge of ceremonies."

Even though Rabinas Finkielsztein and Grynberg do not usually perform wedding ceremonies, they both "recovered" the mikveh ${ }^{130}$ as part of a ritual for brides before their wedding. Both Rabinos Avruj and Skorka remarked what a wonderful job Rabinas

\footnotetext{
${ }^{129}$ Orthodox rabbis would not recognize a Ketubbah signed by a woman as witness, considering it invalid.

${ }^{130}$ The mikveh is a ritualistic bath traditionally used for the purposes of purification. In the Conservative movement, some congregations are re-incorporating the custom for brides to immerse themselves in the waters of the mikveh before their weddings. This has been always practiced within the Orthodox movement.
} 
Finkielsztein and Grynberg are doing, and said that was something that they, as men, would have never been able to do before. Both rabinas also told me that they are in charge of educating the couples before their ceremony on several issues pertaining to matrimony, as explained in chapter $\mathrm{V}$.

\section{Innovation of Rituals and Ceremonies}

Rachel Adler notes in her book Engendering Judaism, that for twenty years feminist Jews have invented religious ceremonies "to fill in the gap" (Adler, 69). Rabinas also make their own personal mark by introducing to their congregations innovative rituals and ceremonies not practiced prior to their arrival. Rabina Chemen introduced the ceremony celebrating Rosh Chodesh ${ }^{131}$ (the New Moon), in which women gather together to discuss and analyze the upcoming month. "According to the tradition, each month has a determined color and energy. [Women] read, meditate, and share a moment together" 132 (Elizalde, 212). Rabina Finkielsztein also leads a Rosh Chodesh group in her congregation.

Rabinas Grynberg and Finkielsztein introduced a $T u$ Bi'shvat ${ }^{133}$ seder in which people gather for a meal featuring fruits in honor of the holiday. Rabina Grynberg told me that she first held a Tu Bi'shvat seder in conjunction with Rabina Finkielsztein, and since then, she has been doing it in her congregation every year. Rabina Szuster told me

\footnotetext{
${ }^{131}$ Rosh Chodesh comes from Talmudic times, and it was celebrated every new moon. Rabina Chemen told me that it is said that women were the only ones who were able to converse with the lunar cycles.

${ }^{132}$ My own translation.

${ }^{133}$ A Jewish holiday also known as the New Year of the Trees.
} 
that in her congregation, she tries to find ways in which women can have a respectful place in tradition. She told me:

For example, something we do here, besides placing the cup of Elijah, the prophet, on our seder's table [for the holiday of Passover], we placed the cup of Miriam the prophetess, so women can also feel [represented] in the seder. We have the opportunity to innovate, this is not forbidden, and is part of our tradition. We have to revitalize some practices we have, but focus more on inclusivity for women."134

As Riv-Ellen Prell observes, these innovations provide the opportunity "for Jewish women to mirror for one another what Jewish women could be" (Adler, 69). The innovative rituals rabinas have developed fill a vacuum and create opportunities for women to express their own spirituality.

Rabina Chemen expressed ambivalence towards changing the liturgy and prayers in order to make them gender inclusive. She explained the importance of maintaining a unified and consistent tradition throughout the world:

Some people changed the siddur (prayer book) adding the matriarchs [when mentioning the patriarchs]. I believe everybody has to pray the same way. I am representing the matriarchs when I mention the patriarchs from the pulpit, because it is the action that speaks, not the words. All those are cosmetic changes that without action mean nothing.

She told me she respects boundaries. She does not sign the Ketubbah as a witness. She does not blow the shofar, even though she knows how to do it, and does it to show and teach children, she refrains from doing it during the required ceremonies because the mitzvah is "lishmoah kol shofar" (listening to the shofar.) "Women do not have the mitzvah of blowing the shofar," she explained, "so if I blow it, I would not let anybody else fulfill the mitzvah of listening [to the shofar.]" 
Over time, these rabinas brought to their own congregations many of the same changes introduced by women rabbis and Jewish feminists in the Unites States. However these changes were dependent on the space and opportunities granted by the rabinos with whom they work. In the case of Rabina Vitas, who works as a sole rabina, the changes she can introduce depend on the support of the congregational Board of Directors. Rabina Szuster is an exception, since she clearly divides all activities with her husband, Rabino Pavolotzky, within their congregation and home. In congregations where a rabino and rabina work together, the division of tasks is gendered. Moreover, the relationship they have as a duo 'rabino-rabina' mirrors a marital relationship, in which rabinas become like "congregational wives" of their rabinos. Each rabina asserted that she is not rabina of women, but of her congregation as a whole. Nevertheless, it seems extremely important for them to establish activities and ceremonies that only pertain to women, bringing their own femininity to the rabbinate and enhancing the experiences of other women. The fact is noted by several rabinos who, on various occasions, stated that they would not be able to execute certain activities performed by the rabinas, because as men, they lack the sensitivity and femininity rabinas have. There is a need for 'genderizing' certain rituals in order to make them appropriate for rabinas to perform; if the ritual involves some feminine element, the rabinas do it. Rabinos are able to take brides to the mikveh, however, that ritual was not practiced before the arrival of rabinas. Rabina Grynberg initiated and teaches classes on how to keep a Jewish home, illustrating her understanding of the importance of marriage, and yet she cannot perform the ceremony. Rabinos seem to be authorized by congregants to bring two people together in marriage, while rabinas are seen more as guides than authorities in this matter. 


\section{Rabinas Outside the Synagogue and their Congregations}

Besides the tasks and activities rabinas perform within each of their congregations, they are all involved in activities outside their congregations. Some even participate outside the Jewish community. Rabina Szuster believes that her psychology degree is extremely helpful when it comes to dealing with people, not for psychoanalyzing them, but for helping them. Reaching out to people is one of the things she really likes about her job as a rabina. She is involved in social work, within the Jewish community in Costa Rica, but also outside of it. She is frequently invited to deliver lectures, usually about women, however she recalled two specific invitations which surprised her. The first was from members of the Centro Israelita ${ }^{135}$ who asked her to speak about Kabbalah. "I was surprised," she said, "because I am usually invited to venues outside my congregation to speak about women, as it would be the only thing I know and can talk about." There are also non-Jewish institutions that have asked her to give speeches and teach courses. A group of female history scholars asked her to discuss women in Judaism and her experience as a rabina. However, she also told me that when people call the congregation requesting a rabbi to deliver a speech, "they usually ask for Rami [Rabino Pavolotzky], not for [her]." The fact that people outside the congregation believe a rabina only knows about issues related to women, and that "the rabbi" is Rabino Pavolotzky, confirms that the division of tasks according to gender is observed not only within the organization, but also in the general society.

\footnotetext{
${ }^{135}$ An Orthodox congregation in San Jose, Costa Rica.
} 
Rabina Baumatz held the of Executive Vice President of the Rabbinical Assembly for Latin America position for a period of time while working in Lamrot Hakol, and during her last years in the congregation, she was also Director of Rabbis' Placement for Latin America, a position from which she retired over a year ago. She offered different courses on a wide variety of Judaic subjects in Lamrot Hakol and in other institutions as well. She also coordinated a group of women's interreligious dialogue in Vicente Lopez, in the province of Buenos Aires, and remains friends with some of the participants. Rabina Vitas is currently the Director of Rabbis' Placement for Latin America, and she also teaches courses and gives speeches on a variety of Jewish subjects around the country.

Rabina Finkielsztein, besides being in charge of everything that has to do with education within her congregation, is also in charge of refuah shlemah, a group which provides visits and prayers for members of the congregation who are sick for a speedy recovering. She organizes spiritual retreats for women, in which they learn and meditate together, and delivers speeches - many related to the role of women, but also on other subjects - to non-Jewish organizations. She participates in interreligious dialogue with other women, Catholics, Christians, Muslims, and lay women, discussing different subjects pertaining to women. She mentors teenagers in community leadership. She meets with another group of women to "read from the Torah and re-interpret the texts in order to provide a feminine point of view." Rabina Pajecki-Lederman is extremely involved in education; nevertheless, she also makes time to participate in interreligious dialogue and speaks publically outside her congregation. Since she is the only rabina 
currently working in Brazil, she receives many requests to talk about her experience and the subject of women and Judaism.

Besides all the work she does within Comunidad Bet-El, Rabina Chemen is also active outside the Jewish community. She told me:

Outside of the Jewish community, I am better accepted [as a rabina] than within. I participate in a lot of interreligious dialogue. I am a member of the Forum for Religious Discrimination representing Judaism. Look at this, Dani [Rabino Goldman] was asked to take the position; instead, he sent me. I am in a position that depends on the President of the nation, and it is me, a woman representing the entire Jewish community in Brazil.

The Catholic Church sent her-all expenses paid—to Israel for a conference on interfaith dialogue. She has even met with the Pope twice. "For them," she said, "there is no doubt that I am a rabbi."

Since her installation in Benei Tikva, Rabina Grynberg tried to introduce many changes. She introduced different activities for families with children studying in Talmud Torah. As mentioned earlier, she introduced many innovative pre-wedding activities for brides and grooms. ${ }^{136}$ In 2010, for the first time in the history of the congregation, she accompanied a group of thirty-six congregants to the first Jewish Settlements established

\footnotetext{
${ }^{136}$ She told me that even though Rabino Skorka is the one who attends the Sabbath dinners they make for couples married in the congregation, she spends a lot of time with the brides. Besides taking them to the mikveh where she recites the blessings with them and finishes with a toast, she always does a very special thing with all of them. She explained to me: "I give them a little box with a Greek story inside that says that when a bride gets married, she needs to receive an empty box as a present, and she needs to put flowers petals inside the box , starting with the ones from her bouquet, and then from every other one her husband brings her. So if she ever has a problem, she needs to open that box and smell the flowers to remind her of the good moments she has spent with her husband and this will make it easier to go through the hard moments. A man does not do this, so I put my feminine touch on different activities."
} 
in Entre Rios, hosting Friday night and Saturday morning services as well as a Sabbath dinner with members of a local congregation.

All rabinas are very active within their congregations as well as outside, and almost all of them told me that outside the Jewish community, more than within, they are accepted as rabinas, and their position is not questioned. Within their congregations, they had to work hard and prove themselves as capable as men in order to be respected as leaders. When their expertise as rabinas is called upon for a course or speech, it is almost always related to women's issues and subjects, even though they are equally knowledgeable and educated in other Jewish subjects. Perhaps because they are expected to perform certain roles and not others, they become stereotyped as experts in women's issues and nothing else. Beyond this, there are other stereotypes in Latin America rooted in the accepted family dynamic and the roles of mothers and wives within it.

\section{Rabinas on Family and Motherhood}

One of the main concerns of the rabinas is the proper "balance" between the demands of their professional and personal lives. Their congregations become an extended family; but in addition, the rabinas have their actual families to tend to as mothers and wives. The seven rabinas are married, and all but Rabina Finkielsztein have children; Rabinas Baumatz and Grynberg are grandmothers as well. Rabina Chemen told me that Latin American rabinas place a great emphasis on their own families and make them a priority while in the United States, by contrast, there are many 'rabinas' who are either divorced or single, "because they chose to put their careers in first place." In his book, American Rabbis, Zucker also notes that "female rabbis seem to experience fairly high rates of 
divorce" (Zucker, 155). According to Zucker, the "burden" of motherhood is also discussed in literature dealing with women rabbis; he cites cases of women who had to leave their jobs as rabbis because motherhood had proven to be too much of a strain. In some cases, even women rabbis are critical of colleagues who choose to limit their rabbinical duties in order to spend more time with their children (Zucker, 156-158). Rabbi Elise Goldstein was asked to officiate at a funeral during her maternity leave, and when she refused "synagogue members were furious" (Zucker, 156). For the rabinas, the importance placed on their families and motherhood is not an issue at all. On the contrary, they feel it helps them perform their job better, and their families are respected and taken into the consideration by all members of their respective congregations. Since all of the rabinas asserted that being mothers made them better rabinas, I wanted to further investigate the relationship between their private and public roles, what family and motherhood means to the rabinas, as well as how and why it influences their work

Rabina Finkielsztein met her husband while she was in rabbinical school and has been married for over seven years. She recalled the difficulties they endured when she left for Israel to study and they spent a lot of time apart. For almost a year and a half they maintained a long-distance relationship, however, he was always very supportive of her decision. Rabina Finkielsztein said of her husband that being married to a rabina is difficult for him "because in general, the norm is for the woman to be the one accompanying the man. A man accompanying a woman is rarely seen, but in our case, it is part of our pact as a couple." She told me that her husband is not always by her side and does not attend every one of her activities. This fact supports my thesis; 
organizations and society in general in Latin America are gendered, therefore it is still outside the norm to have a man playing the supportive role to a woman in a position of leadership. Nevertheless, she told me that in general, he accepts her being a rabina.

Rabina Grynberg left her three children and husband when it was her time to go to Israel. She said it was very difficult, and that missing her children's birthdays was like "missing a whole year of [her] life." But she remarked how grateful she was for the support of her husband, who stayed behind in charge of their home and three teenage children, and made it possible for her to have such an "enriching experience." She also told me how proud her husband is of her, but that sometimes "it bothers him." Rabina Grynberg said that a friend of hers jokes that instead of him being the "rebbetzin" (rabbi's wife), he is the prince consort. The paradigm of a woman in a leadership role with a man acting as her support remains outside the norm, a fact that illustrates the persistence of stereotypes in Latin America. Nevertheless, Rabina Grynberg's husband is supportive; she just understands that he cannot always be by her side.

For Rabina Baumatz, her family has always come first. When she decided to enter rabbinical school, she asked to be exempt from the year of studies in Israel. She made that clear in an agreement signed by the dean, which she still keeps as a special treasure. She explained to me that her daughters were about to get married, that her husband could not travel with her because he needed to work, and that she was not going to leave him for a whole year. Her condition was accepted and instead, she went to Israel for one month in 1990 for an intensive course. Rabina Chemen went to Israel only for a semester, and decided to take her two children and husband with her. However, for her it was not as 
easy as a written petition to the dean. Rabina Chemen had visited Israel almost ten times

before, taking Hebrew and Holocaust courses in the University of Tel-Aviv, and spending two months with an archeologist. She argued that she already had the knowledge of Hebrew and experience of living in Israel. Teresa de Elizalde recounts the story in her book:

[Rabina Chemen] stood in front of the dean and told him: "I am not here to ask for anything, but to offer you only a semester. If you accept this, I will go with my family to Israel for four months. If you cannot accept it, I will quit rabbinical school right now, 'thank you very much for all you gave me;' I will not get my ordination." The dean replied "this will set a precedent," to which Rabina Chemen said "I wish with all my heart for this to set a precedent, for the people who have been working over thirty years on this, who have the [necessary] knowledge of Hebrew, and who have been as many times as I have been to Israel, so that they should not have to go for a whole year to Israel. I do want to set a precedent." [...] The dean formed a commission ad hoc to revise the case. Rabina Chemen stood in front of them and said: "Joan of Arc sacrificed herself for all [women].Women have stopped being burned; the Inquisition has been over for a long time. I think I am not being well evaluated as rabina if you believe that I should leave my husband and my children for a year. I will leave now, but you will have to explain this to the more than 700 hundred children I prepared for their bar and bat mitzvah ceremonies; that I am not a rabina because I am not willing to sacrifice my family." She turned around and left. When she got home, she got an email allowing her to travel only for a semester [to Israel]. She had won. (Elizalde, 215-216).

Rabina Chemen told me, "If I am supposed to help the families of my congregations, why would they ask me to sacrifice my own family?" So she went with her family, and put her younger son in school while the oldest took a course on interreligious dialogue. This shows the importance she places on her family. She explained that the problem is that the prototypical image of a rabbi is similar to that of a Catholic priest, "who loses his personal identity for his service and vocation." However, it should not be like that. Since she believes that the rabbinical role of a woman involves a great deal of mothering, the 
closer she is with her family, the better rabina she becomes. Therefore, she does not hold meetings at night, because she has dinner with her family, "and the congregation accepts and respects that."

Rabina Pajecki-Lederman told me that since Rabino Gottfried is the main rabbi of the congregation he is therefore in charge of all life-cycle events. She is mostly in charge of curricula, youth, and developing new programs. However, when Rabino Gottfried is absent, she has to fulfill those tasks as well. She told me how she complements Rabino Gottfried's work and how difficult it would be without him there, because having him allows her the flexibility to adjust her schedule to spend time with her two children and husband. She explained that there are two issues associated with rabinas and their leadership role. The first one has to do with the perception in Latin America that a rabbi needs to always lead and be on the pulpit. She attributes this idea to the style of Rabbi Meyer, a strong role model who always led from the pulpit and set as a precedent that being in a rabbinical position of leadership means having to lead from the pulpit. That is not her, and she told me how much it bothers her when the fact that she is not leading from the pulpit undermines her role as rabina. "We need to understand," she said, "that we can lead without being at the pulpit. I want to participate in services, but have other people leading and guiding. I am softer." She told me that some members of her congregation told her that because she is a rabina, she had to be like Rabino Gottfried, and she replied that she was a rabina, but different, because being a woman is different. She believes her example as a mother is extremely important in the congregation, and told me, "When I am in the pulpit and my children run to me, I can prove that I can do 
both things: be a mother and a rabina." This leads to the second issue, the fact that, according to Rabina Pajecki-Lederman, people see leadership roles as hierarchical and not human. She explained:

When they see you are a mother, it should help people understand that leadership could be less hierarchical, more horizontal. It also helps them understand that rabbis have a personal life and should not be available for the congregation twenty-four hours a day, and that, for me, is giving a good leadership model.

She told me that in Brazil men still think that women should stay home and that sometimes she "buys" that idea and stays at home herself, because she considers it important for a mother to spend time with her children, and this way, she sets an example. Her husband is very supportive of her as a rabina, and that while he sometimes refuses to accompany her to events that she would like him to attend, she understands because, she says, "he also works a lot and needs his own time. He already gave a lot of himself to be with me, so we sometimes choose to have our own things."

The case of Rabina Szuster is different because she works with her husband; therefore they share all their tasks in the synagogue and at home. They take turns; one teaches while the other one stays home with their two children. They have also received help from the congregants. One congregant told me during my visit that she used to babysit Rabina Szuster's children while both rabbis were in services. Rabina Szuster said that for a long time only men were rabbis, so now it is difficult for a woman to be accepted as such. Still, she believes that the rabbinical career involves skills that are traditionally associated with women, such as teaching, care-giving, and assisting people. Rabina Szuster thinks that as a woman, she has more empathy for people, and that this 
helps her a lot as a rabina. She told me how she tries to balance family and work because they are both important aspects of her life. As a rabina, as much as with any other job, she said:

It is important not to stay at home all day, because one misses the possibilities of developing different capacities. It is not easy because women have to stay home with their children more often than men. In my case, I am lucky because with Rami, we share both tasks [the keeping of the home, and rabbinical work in the congregation.] But in general, men do not take care of their children, they always have the wife do it.

Rabina Szuster believes in the importance of having rabinas because women can also have a rabbinical vocation, and serve as role models for girls and other women. The problem in Latin America is that not everybody is ready for it. She thinks that as a rabina, one of the biggest barriers she faces is get a job in which she can express herself freely. Furthermore, she sees that there is still a long way to go, because even rabinos are not yet pushing for this change.

Rabina Vitas struggled for a long time as a rabina, and told me that even though it is accepted for women to do the same things as men in synagogues and liturgy, imposing a rabina on a cemetery or wedding ceremony is still very difficult. The importance she placed on her family and the love she has for her career were difficult to negotiate at a point in her life. When she took the job at the congregation in Entre Rios, she moved with her family, but as her husband was working in Buenos Aires, they would only spend the weekends together. It was very hard for them, and she decided to move her family back to Buenos Aires, so the last months she worked in that congregation, she was commuting between her family on weekdays and weekends in the congregation. She explained that she always emphasized the importance of family, not only her own, but those in her 
congregation. Now that she works in Or Jadash as sole rabina, she also faces many challenges. She was originally hired in partnership with a rabino, but at the last minute he decided not to work there. "The congregation debated the issue of hiring me as sole rabina for a long time," she said, "and there is still not a general consensus on my appointment. They are waiting for me to hire somebody else, maybe a male rabbinical student to help me." In July 2010, she told me they were requesting that "so they have that masculine role covered." Rabina Vitas offered two reasons for why she thinks her congregation wants that. One is because it is a large congregation with a school of 400 students and there was a big load of work in that area. The other reason is prejudice against her being a woman and a mother, and because she would have to take time off to help at home with the children, "taking them to the doctor when they are sick, or helping them with their homework." Later, in an email in November she told me that having a masculine image of a rabbi was still important, but that she was looking for somebody to work with her not to appease expectations, but because there was a lot of work to do and she needed help. She works a lot, but since the mornings are slower, she goes grocery shopping and drops her children off at school during that time; her husband is in charge of the children in the afternoon and evening. She said, "I can do everything because I have a husband who juggles being a husband, father, mother, and wife. This is the only way. Our job as rabinas is full life, not full time." She also told me that weekends are exclusively for her family, unless there is a special event at her congregation.

The importance rabinas place on their own families is generally respected by their congregations, and it enhances their work, because, after all, they become mothers to the 
congregants. Moreover, the relationship they have with their respective rabino partner is also a reflection of the familial relationship: rabinas are there to support them, leading from a different side, their maternal and feminine side, complementing the rabinos work from a different perspective. Therefore they are "congregational wives" to the rabinos. Motherhood is so intrinsic to these women and to Latin American society in general, that it drives them to become better at their jobs and simultaneously earns them respect.

Furthermore, motherhood is what differentiates rabinas from rabinos, giving the women a unique characteristic and possible advantage that the rabinos lack. But what do rabinos think about rabinas and their work? How do they see the role of rabinas?

\section{Rabinos' Thoughts on the Importance of Rabinas' Work}

All rabinos agreed the rabinas have done tremendous work and made extremely important changes within their congregations. They also recognized the persistent stereotype in Latin American Judaism of rabbis as men. Rabino Pavolotzky told me that sometimes they encounter people who only want to talk to him because he is "the rabbi" and that he found himself explaining that both, he and Rabina Szuster are the rabbis.

Rabinos Skorka and Avruj noted how important it was to have a different view. Rabino Avruj asked:

Who says that everything has to be the same? The stamp of creation is diversity, there are different colors, not only black and white, [otherwise] it would be boring, and that does not mean that one color is more important than the other. In this diversity, we have to integrate ourselves, each keeping our own identity and color, and that enriches us collectively. From her view as woman, [Rabina Finkielsztein] brings things to the job that I cannot, and [vice versa]. 
Rabino Skorka assured me that the decision to bring Rabina Grynberg was right, and one of the reasons he gave is that "she can give a feminine point of view in the sermons.

Feminine is totally different from masculine, but they complement each other." However, he told me that the male image of a rabbi that people have in their minds is very hard to change, and that it is a cultural thing. Nevertheless, he recognizes the work Rabina Grynberg has done for the rights and equality of women within the congregation, and he asserted that without her, the congregation would not be egalitarian. He affirmed the significance of having a rabina in the congregation:

The rabbi has to touch very sensitive fibers in other people, and your gender determines how you project that sensitivity. That is why I believe it is not the same [to have a rabino or a rabina]. There are many aspects that are not the same - reading from the Torah, leading services - but the sermons have to be gendered. Look at Deborah, [she told Barak] 'I will go [to fight], but know that if I go to the battle, the military honors will not be yours, because a woman helped you win.' War was men's business because it involved strength. Women fight from a different angle. In Hebrew the word rachamim (mercy) comes from the word rechem (uterus), and the word emunah (belief), maybe comes from omenet, the person who nurses the child. So there are different characteristics that make a human.

Rabino Skorka's point is that Rabina Grynberg possesses characteristics that he, as a man, does not have, and by offering both, they are able to provide a better example to their congregation.

Rabino Goldman told me that in Bet-El, maybe it was hard at the beginning for Rabina Chemen to be accepted because there were a few people who "had a more traditional idea of what a rabbi is," relating it to a man, not a woman. But Rabino Goldman wanted to make clear to me that for him it was not a matter of gender, but a matter of roles. He understands that men and women act differently, and the way he as a 
man conveys an idea might be different than the way Rabina Chemen, as a woman, expresses the same idea. He knows that there certain traits and behaviors pertaining only to men and others only to women, however, he does not want to define them through the roles he and Rabina Chemen have. Though he accepts that her discourse as a woman could be perceived differently than his as a man, he said, "I want to emphasize that the rabina working here does not do it from her role as a woman, but from her place as a rabbi. In our daily treatment she is a [rabbi], ${ }^{137}$ not a woman."

Rabinos' words reflect cultural beliefs in Latin American Judaism that are still strongly rooted in that society. Since rabinas are still a very recent phenomenon in the region, the image of a rabino as a leader is still predominant over that of a rabina. This has nothing to do with the personal capabilities of these women as individuals or as rabinas, but rather with popular culture. It is also worth noting that most of the rabinos felt that because of their gender, the rabinas complemented their own roles as rabinos. Rabino Goldman is the only one who told me it was not a matter of gender, while the other rabinos classified it as the distinctive characteristic that makes rabinas' work important and relevant.

This chapter illustrates that the title of rabina and the roles associated with this title are manifold and complex. On one hand, it is clear that rabinas are not only allowed, but as capable as rabinos to preside over rituals and ceremonies, nevertheless, there are still ceremonies that they do not usually perform. The rabino is still perceived as the main

\footnotetext{
${ }^{137}$ He used the word "rabino" referring generically to a rabbi. Since it is a masculine word in Spanish, for a better understanding of what Rabino Goldman meant, I have translated into the word in English, emphasizing the fact that it should not have any gender.
} 
authority in certain ceremonies. On the other hand, women are re-appropriating Jewish customs and symbols, and rabinas are no exception. They take symbols traditionally linked to men and make them their own by providing a "feminine" touch. Even though there is no general agreement between the rabinas on the issue of "feminizing" certain symbols, it is clear that they use their femininity to lead their congregations. The importance they place on motherhood and on their own families enables them to be better role models and better leaders, and they are considered authorities for subjects relating to women not only by congregants, but by the rabinos and society in general. While it is still outside the norm in Latin America to see a woman leading and a man supporting her, the rabinas are imposing a new model of leadership in which they take the accepted role of women (as mothers and wives) and apply it in their workplace, leading from their feminine side and complementing the daily tasks of the rabinos. Being feminine and applying that femininity to their daily work becomes a particular characteristic of the rabinas, and this brings us back to the issue of feminism and its perception in Latin America. So what are the rabinas thought on feminism? How do they define themselves? 


\section{Chapter VII}

\section{Me, a Feminist? Rabinas' Understandings of Feminism}

There is no doubt concerning the impact of Jewish feminism on the ordination of women as rabbis. As previously noted in this work, in their search for equality, Jewish feminists prompted many changes in different areas of Judaism, reinterpreting sacred texts, adding inclusive language to prayers, and increasing the inclusion of women in ceremonies and rituals. Throughout the movement's different waves feminists sought to improve the quality of women's lives by broadening their rights—-both personal rights and rights within society at large. Consequently, it was surprising to me that only two of the seven rabinas I interviewed would define themselves feminists. Moreover, the five rabinas who do not consider themselves feminists were very critical of feminism, providing welldeveloped arguments against it. In this chapter I will investigate the rabinas' negative perception of feminism and try to understand their reasons, as well as what makes the two "feminist" rabinas different from the rest of the group. To do so, I will explore their respective views of feminism, and where those understandings are rooted.

\section{The "Feminist" Rabinas}

While trying to understand why only two rabinas define themselves as feminists I realized that both do not live in Argentina. Rabina Pajecki-Lederman lives in Sao Paulo, Brazil and attended rabbinical school at the JTS in New York City, and Rabina Szuster lives in San José, Costa Rica. Rabina Pajecki-Lederman told me, "I do consider myself a feminist as a tribute to the feminists who opened the way for me to be able to have the 
access I had to the study of the Jewish tradition. I feel I owe [it] to those women who did not have it easy and had to fight for something that today I take for granted." Her answer did not surprise me because her training at the JTS in the United States gave her greater access to the knowledge of feminism and its struggles and victories on the advancement and equalization of women within the Conservative movement. She mentioned to me that her class composition was fifty percent women and fifty percent men and that she did not feel discriminated at all for being a woman. "I only had one Talmud teacher who had issues with women," she told me, "but he was such a minority." This is how she rationalized that teacher's behavior: "He was like my grandfather, so you understand your grandfather having those kinds of issues." The path had already been cleared for her by Jewish feminists who over three decades earlier paved the way for women's ordination.

Rabina Pajecki-Lederman recognized the difference between American and Brazilian societies. The image women have to project in Brazil is very important and is what defines their womanhood. The stereotypes of tight-bodied, beautiful Brazilian women dancing in small bikinis during carnival are well known by all, and the pressure to look like the stereotypical Brazilian woman is lived daily. In addition, the idea of the man as head of household is still important. "In the United States" she told me:

Boundaries are very clear in all senses and identity is very important, and that impacts women and Judaism. Brazilians have hard time defining themselves. Women especially here have hard time because they are afraid of stepping up into certain roles and lose their femininity by not looking on certain way or doing certain things; women always have to be fragile. 
A woman in a leadership role does not portray that image of a 'hot, feminine, Brazilian woman;' she is uncommon, and makes some people uncomfortable, even other women.

Rabina Szuster was trained at the Seminario Rabínico Latinoamericano, and explained to me that she did not know about feminism until she went to study in Israel. "In Israel, women do things together and think about themselves and their position together, searching to build something new for themselves." She defines herself as a feminist because, she said, "I think women have the right to express our spirituality and aspects of life as men do, not in the same way, but we have the same right to do so. I do not think women are better; I try to find equality, not treating people differently because of their gender." She also told me that even though she considers Costa Rican society more "closed-minded" than Argentine society, when it comes to women's rights, Costa Ricans do protect women and defend them and have a fairly organized feminist movement. "Compared to the rest of Central America, [Costa Rica] is one of the most open societies" in its defense and fight for women's right. She also understands and recognizes the influence of feminism in the changes made within the Conservative mainstream towards women's equality.

She feels one of her goals as rabina is to change some of society's predetermined ideas regarding women. In her opinion, society tells us that women must be in charge of many things — such as the home and children — and that women should be constrained by those roles and nothing else. "The challenge for me is changing that," she said, and claims to do so by not behaving in expected ways and breaking stereotypes. By sharing tasks with her husband that she as a woman is 'supposed to do,' she shows that women 
can break out of their domestic roles and take on ones of leadership. She believes that society places a lot of responsibilities on women and not men, and that this creates an imbalance which must be corrected. It is extremely hard for a woman to get a job in Latin America, because, according to rabina Szuster, societies in the region are very machistas and that is "a cultural thing." She expanded the idea by telling me that "it has to do with the socio-historical context of Latin America, in which women are not seen in leadership positions as often as men. It is definitely different in the United States, where the feminist movement is big on the fight for equality, but here [in Latin America], we are far from that." Not only does she defines herself as feminist, but she lives the part, fighting to create spaces of equality in which women can develop and advance in areas besides the family and home. She recognizes that Latin America still lags behind the United States in women's equality, but remarked that she would not have made it to where she is without the help and support of her husband, Rabino Pavolotzky.

Both Rabinas Szuster and Pajecki-Lederman know the task ahead of them is difficult because it requires that they prove themselves to everybody, and furthermore, that they do so in a society that has for years been rooted in particular stereotypes of women. However, that does not stop them from trying to make changes and to prove that, as women, are also capable leaders and examples to others.

\section{The "non-Feminist" Rabinas}

All rabinas who self-defined as non-feminists live and work in congregations in Argentina. I was surprised by this fact since Conservative congregations in Argentina, particularly in Buenos Aires, are perceived as progressive within the movement. As many 
of the rabinas told me, Buenos Aires has always been deemed in the vanguard, ahead of other congregations in its willingness to adapt to modern times. Nevertheless, Argentine society remains very traditional in its views on women and their role. All but one of the non-feminist rabinas are older than Rabinas Szuster and Pajecki-Lederman, but for me, age did not determine what they thought about feminism. Rabina Finkielsztein, the youngest one of all, told me something that surprised me greatly. She mentioned that "When [she] came back from Israel, [she] came 'very feminist'." She told me:

I was able to be there with a group called nashot hakotel. ${ }^{138}$ I believe we have to search for equality but without going to the other extreme, without turning into the opposite of machismo, but building something together with men. Before I used to think that I had to fight for women by generating spaces of study for them. Now I believe that we have to deal with the issues of women but with the entire congregation in general, not just with women. When I started with those groups exclusively for women, some men approached me and asked me why I was doing that, and said that by alienating myself just with women I was gaining the opposite of what I was trying to accomplish. I now believe in the importance of studying men and women together, learning about different models of men and women in the different Judaic sources. The construction of the ideal man and woman has to be done in community and not divided by gender.

\footnotetext{
138 "Women of the Wall, or Nashot Hakotel in Hebrew, is a group of Jewish women from around the world who strive to achieve the right, as women, to wear prayer shawls, pray and read from the Torah, collectively and out loud, at the Western Wall (Kotel) in Jerusalem, Israel. The Western Wall is Judaism's most sacred holy site and the principal symbol of Jewish people-hood and sovereignty and Women of the Wall works to make it a holy site where women can pray freely. Conducting such prayer services remains illegal under Israeli law, which singles out women." The word for women in Hebrew is Nashim; usually words ending in im are the plural masculine form while the plural female words end in ot. The word nashim is an exception to the rule. The group felt the need for "a pro-female assertion that seeks to remove the linguistic dependency of the word woman or women on the word man or men, since unfortunately these female words have largely and historically been characterized as a 'derivative' of the male, a statement which has social implications" (Sigal n.d.).
} 
She told me that nashot hakotel began to influence her greatly, but then she realized she was making a mistake. She recognized that doing things for women only would only segregate women more and establish tension between men and women of her congregation. By trying discussing women's issues with women only, men felt she was becoming a female "machista." It could be that maybe Rabina Finkielsztein and I had different understandings of feminism, so I asked her to tell me what feminism was to her.

She said:

For me, feminism is an extreme in which women are defined in opposition to something else. You say, 'feminism' and Simon the Beauvoir comes to my mind. I remember she said women have to rewrite the Bible and take out everything in it that is against women and write a new Bible. I do not believe in this. This is what I think of as feminism. What we have to do is create new interpretations; the Torah will always stay the same. We have to read it and interpret it with the eyes of our times, generating new material to enrich our culture, not erasing what we have been throughout history but building on top of it; because the ultimate goal is to build equality inside people. Feminism and machismo generate opposition and nothing together.

For Rabina Finkielsztein, being a feminist means fighting not for the equality of women, but for their supremacy, it means erasing from history any traces of misogynist thoughts and actions., and people from her congregation perceived her actions as being exactly that. The issue of the feminine came into our conversations as well. She told me that Judaism needs a feminine view, and that as a woman, she can offer different interpretations and explanations of why rituals and customs are practiced in certain way. While she rejects the label of feminist, she does embrace her femininity and finds it useful for reinterpreting texts and redefining rituals. During her time in Israel, she had contact with feminists and lived their daily fight, a fact that seems to have faded away once she returned to Argentina, where her focus on women and women's issues caused 
her to be perceived as anti-men. This experience illustrates that feminism is still considered extreme in the Jewish Conservative movement in Argentina, and I attribute this perception to the stereotype of women as mothers, submissive and secluded in the privacy of their homes.

Rabina Finkielsztein was not the only one to express the feeling that feminists are anti-men and only searching for women's supremacy; Rabina Chemen told me that she is not a feminist because "[she] is not advocating for a world in which women would take power." In graphic, she referred explicitly to her body, saying, "I am feminine; I do not have [a male anatomy] but [my anatomy] means that I have spaces for so many other things men cannot hold." With her statement she made clear that even though she has physical differences with a man, those differences embrace what she is as a woman, and that through those differences she can gain experiences that she can later share with others. Again, the issue of being feminine but not feminist came up in our conversations. She believes being feminist is bad, but that femininity could help pave the way to equalization. Rabina Chemen told me that the problem in Argentina is that society degrades women, because "the place of the feminine is in a naked body, or in the lust of Marcelo Tinelli, ${ }^{139}$ and that degradation goes against the place of women [in society]." Therefore, in order for women to succeed in male worlds they have to operate in masculine ways, and this also degrades women. She told me that she saw many rabinas in other parts of the world acting like that, with an "androgynous typology." She defines herself as a common person who, despite being a rabina, does not cease to be a woman,

\footnotetext{
${ }^{139}$ Marcelo Tinelli has been the host of a variety-type TV show since the 1990s. For the past ten years he has featured different types of contests, such as dancing or ice skating, in which women with voluptuous bodies are shown wearing very tight and tiny clothing.
} 
meaning that she can be feminine without being "grotesque," and that she can lead from her femininity.

Rabina Chemen is extremely involved in the re-interpretation of biblical texts, publishing books and essays. She contributed an essay to the book, "Torah: a Women's Commentary;" in it, she reinterprets the story of Zelophehad's five daughters from Parashat (weekly Torah portion) Pinchas, and offers her contemporary view on the issue (Chemen 2008). Her interpretations of different texts develop from her femininity. She explained to me that she dedicated a lot of time to understanding the feminine constitution of the Torah itself, and that the women in it created revolutions from their femininity. According to her, none of the matriarchs accepted the model that was imposed on them, but fought it from their feminine side. ${ }^{140}$ She told me that:

All women in machistas' worlds are infertile, because it is hard to give birth, because in order to get something we [as women] need to put forth great effort and put a lot of work into it. For us, the places we have in society still do not feel natural. The sacrifices we make as mothers in order to do what we like to do, besides being mothers and wives, is great. We as women want to assume certain roles and put so much work into it that sometimes it even hurts us. It is like trying not to die in an attempt to becoming somebody. I believe infertility is the symbol of a woman who is not happy with what she has, so it becomes very hard to give birth. But still, we do as much as we can to [give birth] anyway.

While acknowledging how hard it is for women to gain status and recognition, like Rabina Finkielsztein, Rabina Chemen defines herself not as feminist but as feminine. She told me that the issues of women do not pertain only to women, but to humanity. She

\footnotetext{
${ }^{140}$ As an example Rabina Chemen told me the story of Rachel. She said that "When Rachel could not have kids, she told Jacob 'give me kids because I will die.' Since Jacob told her he could not do anything about it, she brought her servant to be impregnated by Jacob. When her servant was delivering the baby, Rachel placed the woman between her legs so she could feel that she was the one giving birth. It was her way of saying that nobody was going to deny her children."
} 
said, "Our place [as women] has to do with the battles we fight and the status men give us, but even that is based on their own place and role in society. A man who has to fight to not be displaced by a woman is a man who has no idea where he is standing. A man that knows and is secure about his place is more willing to share it." She recognized that her position within the congregation is not only due to her own capabilities but is also possible because of Rabino Goldman, because he makes her feel like the rabina of the congregation and not the rabina of women. She argues that because Rabino Goldman is extremely sure of his own role, he is able to share a leadership role with her, and that is something the congregation perceives and respects. I therefore understood that for Rabina Chemen, her position of 'feminine' leadership is not only a result of her fight as a 'feminine' woman, but also thanks to the support of the rabino who works with her. For her, egalitarianism is gained by the fight of both, men and women together.

Rabina Grynberg told me she did not consider herself a feminist; instead she told me she is egalitarian. She said:

To me, everybody has the same rights. For example, nowadays men also change diapers. The only places where women were relegated [in Judaism] were in liturgy and the synagogue, so I try to be egalitarian in that sense. If a man can wear a kippah, I can do it too, because I consider the ends to which we use it as the same. I do not want to be a feminist, and I do not like it.

She is in search of equality within leadership because she believes it "is important to have a woman for everything, to get her feminine view, and because women can do many more things than men." To illustrate her last statement, she told me that the reason there are more women secretaries than men is because women can multitask. "It was like that in pre-historical times; men would go out to hunt and then bring the animal back, and that 
was all; women did all the rest." So she gave me a different perspective on the issue. She is not feminist; she considers herself egalitarian. At the same time, she knows that as a woman, she can do more things than a man and therefore feels it is important to have women in the same positions as men in order to supplement them.

She also explained to me the importance of giving women a chance to fulfill their dreams, and insisted that providing them with the same opportunities as men is a way to make that happen. Rabina Grynberg is extremely thankful to Rabino Skorka, with whom she works, and to the Seminario for the opportunity they gave her to fulfill her dream of becoming a rabina; it makes her feel that she did not waste her life, and she constantly thanks God for putting her in this world at this time, in which she was able to pursue the career and work of a rabina. Furthermore, she recognizes the courage of Rabina Baumatz as the first woman to enter the Seminario seeking rabbinical ordination. Recognizing that she would not be where she is now without the work of those who came before her, she told me, "Margit was like the first child, the one who opened the birth canal." She never mentioned the fight of women in the United States for ordination; her ordination, she feels, was possible because God placed her here, and because Rabina Baumatz had the courage to go first.

Rabina Vitas was also very drastic in her answers. She told me she is not a feminist because she does not fight to fulfill the roles and functions of men, but seeks the freedom to choose who to be instead. She believes that the rabbinical role should be fulfilled by a person with the capabilities of a rabbi, which has nothing to do with gender. For her, being a good rabbi, irrespective of gender, is a way of setting a good example in 
the community. Before she became the sole rabina of a congregation, she struggled for an egalitarian relationship with the rabino of the congregation she worked for; however, she said it had to do with people's personalities and not with gender. Once congregants got to know her as a person, they were more receptive of her. Throughout our conversations, I was able to apprehend more of what she meant by "people's personalities and particularities." For example, she told me that she would not criticize Judaism for traditionally denying women the same place as men. Instead, she would critique

Society and the people who cannot open their minds, who are filled with prejudices and therefore cannot read the sources from a different point of view, because the sources are influenced by what people know or by the time in which they live. It is clear that tradition and customs are influenced by the time and place in which people live. So I believe that society or the community needs to study the sources from a different point of view, looking at them without the prejudice of all the things they know today. Within Judaism, there is not a single answer to a question, [but many,] so within some of the answers we can find women's answers. The main issue is for these answers to be accepted and respected by all.

Besides not considering herself a feminist, she does not believe that she, as a woman, can offer something different than a man. She does not see herself as currently fighting for her acceptance as a woman, but as a rabina, and she fights for this professional acceptance by demonstrating that she is capable of fulfilling that role.

It seems logical that having fought the same fight as feminists in the United States to become the first woman seeking ordination at the Seminario, Rabina Baumatz would define herself as feminist. Several rabinas, including Rabina Grynberg, said that Rabina Baumatz paved the way for other women to become rabinas. Rabina Baumatz said it herself: "A lot of people told me I was a role model for them, opening the way for everybody else behind me." It was not easy for her, because she was over fifty years old, 
and because nobody at the Seminario was faced with that situation before. When the dean admitted her to the rabbinical program, no one thought she would be able to complete it. The fact that she did not have a degree from an accredited university did not stop her; she pursued another career, pedagogy in separate school while studying in rabbinical school. The fact that the whole tribunal boycotted her ordination on the day she had to take her final examination, did not stop her from showing up again a week later in order to take the exam. And finally, the fact that she was not able to be "rabina de púlpito" (rabina on the pulpit) in her congregation was not an impediment either. Like women in the Reform, Reconstructionist, and Conservative movement in the United States had done decades before her, she proudly sat among congregants wearing a kippah and tallit, showing everybody that she was a rabina. She recognizes the Unites States as being an example, "because women there started before and maybe that helped us to later start here." However, she never mentioned the word feminism to me or the fact that Jewish feminists had pushed for ordination in the United States. She simply told me that nowadays there can be women doctors and lawyers, so why not rabinas? She said, "Why not in Judaism? Why discriminate? And this has been my fight. As women we have the same rights as men - the same rights to study, to perform the same tasks, and if we still have to fight, we will." These, to me, are the words of a feminist who was able to open doors for others to follow her through. For her they do not seem to be words of feminism, but of her own personal struggle to become who and what she always wanted to be, and be accepted as such. When I asked her if she was feminist she answered only that she considers men and women to have the same rights and obligations. 
Feminism is defined in opposition to machismo and as a way of undermining men and is also common within political circles in some countries of Latin America. For example, when Hilda González de Duhalde ${ }^{141}$ was asked in the 1990s about the influence of feminism in Argentina, she responded that luckily it still has not had much influence. Furthermore, she believes that feminism as a current of thought has not succeeded in catching on in society, because common sense tells us that things are not black and white. She said:

To defend women's rights or equal opportunities doesn't mean separating ourselves from men, or leaving to one side all those things which God or nature has set out for us. I believe that feminists have made a mistake in being so extreme, women prefer to be feminine, prefer to struggle for equal opportunities but naturally they want to carry on being the central axis of the family, the protector of life, the [caregiver] of the children (Craske, 170-171).

This view of feminism is repeated in other Latin American countries. In the 1970s, the National Women's Bureau of Chile, headed by dictator Pinochet's wife, Lucia Hiriart, published a booklet in which feminism is defined "as the reverse of machismo: "the desire to impose female dominance over men"" (Miller, 211). This discourse is similar to the rabinas', whose usage of feminist language (such as "the search for equal rights") reflects the influence of feminism in their thoughts, even as they reject the feminist label. This "misunderstanding" of feminism is characteristic in Latin America; therefore it does not surprise me that rabinas who had no direct contact with feminist thought outside of the region still perceive feminism as something negative, while the rabinas whose lives have been directly impacted by these ideas call themselves 'feminist.'

\footnotetext{
${ }^{141}$ Wife of the Peronist governor of the province of Buenos Aires in the 1990s, and established the Liga Femenina (Feminine League) within the Peronist party of the province of Buenos Aires.
} 


\section{Defining the Rabinas}

In previous chapters, I have demonstrated the impact of Jewish feminism on the advancement and equalization of women within different Judaic denominations. I have also provided evidence for how American Jewish feminism influenced and advanced the issue of women's ordination in the Conservative movement. In chapter II, I noted that American Jewish feminism had the greatest impact on the ordination of rabinas at the Seminario, which itself was established by an American Rabbi and was thus influenced by American Conservative Judaism since its inception. Furthermore, Rabinas Szuster and Pajecki-Lederman also recognized this fact and are grateful to American feminists who paved the way for women's ordination. Both of the 'feminist-rabinas' recognize the deeprooted stereotypes in Latin American society, such as men being macho - the one in charge of sustaining the family — and women being pretty, and fragile. Strength is the distinguishing characteristic: the man heads the family because he is strong, while the woman, being fragile, preserves the image of femininity and submission. Although Rabinas Szuster and Pajecki-Lederman seem to differ greatly from the rabinas I call 'non-feminist,' I can perceive traces of Latin American cultural influences in their way of thinking. I specifically would like to remark that even though they both consider themselves feminist; they also both recognize that they would not have been able to attain their current positions if not for the rabinos they work with. The idea that men must validate the positions of women is still ingrained in their thinking.

Ellen Umansky says, "The feminist emphasis on balance has proved to be appealing not just to the vast majority of women rabbis but to a small and growing 
number of male rabbis as well.” In the public's eye, “women rabbis symbolize Western feminism's successful challenge to Judaism.” Zucker believes that whether or not they themselves are comfortable with the mantle of feminism, women rabbis are linked with feminism in the public's perception (Zucker, 149). Furthermore, in her book, Women Who Would be Rabbis, Nadell remarks that almost all women who wanted to become rabbis "fell under the influence, at least indirectly, of the resurgent feminisms' promise that women can and ought to be able to do anything men did" (P. S. Nadell 1998, 199). Whether identified or not as feminists, feminism had a great influence on rabinas' ordinations. Therefore I was extremely surprised, not only by how many of the rabinas considered themselves 'non-feminist,' but by how extremely opposed they were to ideas of feminism. Francesca Gargallo writes that in Latin America "women who demand their rights for equality, the ones that question equality because they do not accept the model in which it has been built, organized lesbians, theologians, and even women in politics that are only interested in the immediate improvement of women's conditions, all define themselves as feminists"142 (Gargallo, 110). Why then do so-called 'non-feminist' rabinas defy this definition?

There are many commonalities between the rabinas currently working in Argentina and the American feminists' who fought to become rabbis. As Nadell remarks in one of her essays, activist feminists including female rabbis and young women across the denominational spectrum who were deeply committed to Judaism "Started out by deepening their knowledge of women in Jewish history and law" (Nadell 2009, 164). The

${ }^{142}$ My own translation. 
rabinas are well educated, in Judaism and reinterpret texts through a 'feminine' lens. They have also implemented innovations in ritual and ceremonies concerning women. Nadell adds that American feminists "were determined to transform all of Jewish Life. Educating themselves and others were the tools" (Nadell 2009, 165). These words sound a lot like the words of the rabinas. My mind is filled with their phrases: "Now little girls look up to me;" "A girl in seventh grade told me she wants to be a rabina like me;" "Margit opened the way for the rest;" "They tell me I am an example." Rabinas are also determined to make a difference. They were ready to make a change when they began their studies at the Seminario, to show that they were as capable of becoming rabbis as men, and that they had something different to offer to the rabbinate. Through their femininity they perform tasks differently than rabinos, a fact that is liked and appreciated by congregants and rabinos as well. Their feminine condition makes them more approachable. By defining themselves as feminine, they are attempting to characterize themselves as softer and easier to approach, and different from men. The idea of machismo as the norm for a leadership role remains so vivid and so entrenched in Latin American societies that it continues to harm women. The fact that the rabinas do not want to "fight for women to the power" and that they believe feminists act like men in order to succeed in a machista world proves this point. The rabinas embrace their femininity because it is accepted as a positive characteristic. As echoed in Rabina Vitas' words, for them, being feminists means fulfilling a man's role, and they want to make sure they are seen as different from men. 
According to Delmar, the aim of "Feminism in general is to attempt to transform women from an object of knowledge into a subject capable of appropriating knowledge, to effect a passage from a stage of subjection to subjecthood" (Craske 1999, 165). The general perception of feminism by Argentine society also influences the rabinas' perception of the movement. Nikki Craske references the ongoing debate in Latin America between 'feminist activity' and other women's organization, which "while reflecting [the] gendered interests [of women] might not be called feminist." Therefore there was a need of distinguishing between the feminine/feminist and feminist/women's movements, among others. The debate reflects the antipathy towards feminism in the region but "also implies that there are women's interests which are not feminist" (Craske 1999, 164). In Latin America, perceptions of the movement are related to the extreme feminism of the 1970s. There is also the issue, as I mentioned in chapter III, of feminist movements being perceived as anti-men. Thus there is a separation in the region between 'feminist' and 'feminine.'

One way of understanding the difference in Latin America between feminists' and women's interests, or between feminist and feminine, is by considering the difference between the strategic gender interests and practical gender interests. Maxine Molyneux defines the strategic gender interests as those that "women (or men for that matter) may develop by virtue of their social position through gender attributes;" they are derived from the analysis of women's subordination and were developed to formulate strategic objectives for overcoming at subordination. The demands formulated on this basis are usually termed "feminist" as "is the level of consciousness required to struggle 
effectively for them" (Molyneux 1985, 232-233). Practical gender interests, on the other hand, arise inductively from the actual and unequal position of women within a gendered division of labor. These are formulated by women themselves rather than through an external intervention, usually as a response to an immediate need and "do not generally entail a strategic goal such as women's emancipation or gender inequality" (Molyneux 1985, 233). Practical gender interests are usually related to the feminine and may not challenge dominant gender roles. "For those women more involved in practical struggles it reflects their priorities as much as a lack of consciousness of gender subordination" (Craske 1999, 167). This distinction between strategic and practical interests is helpful for understanding how rabinas are motivated toward equality. Rabinas have practical interests, because they do not identify their need for equality with gender issues. They do not see their organizations as gendered, however their insistence that they could not have achieved their current positions without the support of the rabinos proves to me that their organizations are in fact gendered; they are work places in which male validation determines the success and acceptance of female labor.

Feminism is particularly an issue in Argentina. Craske notes that the country is "not seen as having a strong women's movement, and even professional women who might be stereotypical feminists in other countries are resistant to be identified as feminists (Craske 1999, 173). For example, women's social movements, such as Madres o Abuelas de Plaza de Mayo, are an alternative way for women to develop feminists' ideas without being catalogued as feminists. Craske understands that feminism is a multifaceted concept which includes many different perspectives and demands. 
According to her "Some women's movements may still eschew the term feminist and will still emphasize the complementary characters of women and men, which may limit the debate" (Craske 1999, 191). Clearly, the term feminism as it is known in the United States does not accurately describe the women's movements of Argentina. As author Gabriela Cerrutti writes of Argentina, "post-feminism is premature [...] since the country was still 'prefeminist' (Craske 1999, 190). I believe all these factors contribute to the rabinas in Argentina defining themselves as non-feminists. The misconception of what feminism is, which is observed throughout the region, is well noted in the answers the rabinas gave me. The fact that they prefer to define themselves as feminine or egalitarian proves that they are trying to distance themselves from ideas linked to marianismo. ${ }^{143}$ Every Argentine rabina claims that she does not want to be the opposite extreme of machismo and that she is in search of equality, but through a shared space. However, their equality and right to that "shared space" is still based on recognition of their merit by men. They do not want to be perceived as anti-men, and recognize that the work necessary to achieve equality is not only theirs; it has to be shared with men, and requires their support and compromise as well.

There is no doubt that the work the rabinas do within their congregations is similar to that done by feminists (rabbis or not) in the United States. They all agree that there is a need to reinterpret the texts through the lens of women in order to better understand why women were treated the way they were in the texts. They also believe in the importance of creating spaces for women to express their femininity and spirituality. All these commonalities tell me that there are traces of feminism in the rabinas; however

${ }^{143}$ Concept explained in chapter III. 
they choose to define those traces as femininity instead. The way they define themselves is less important than how they behave. Most important is that they recognize that as women, they have made and will continue to make an impact on the lives of others through their womanhood and motherhood. 


\section{Conclusion}

My thesis draws attention to the practice of gender differentiation in Jewish Conservative Congregations in Latin America where rabinas hold a position of leadership within the institution. Furthermore, this thesis makes a case for further research on the intersectionality of religion, gender, and cultural identity as a way of understanding rabinas' religious and leadership role within the context of Jewish Conservative Latin America. The present study reveals the gendered division of labor within Conservative congregations in Latin America, in which rabinas are expected to carry out tasks intrinsically associated with women such as caregiving, nurturing and educating. These tasks are also related to motherhood, which plays an important role in women's lives. Thus the distribution of jobs is made according to those characteristics, and relegates rabinas to tasks related to education, particularly that of children in the congregation, as well as to the nurturing and caring for all members. The rabinas fulfill their expected roles by initiating activities and providing their feminine attention to details that otherwise would not be performed by the rabinos.

Although some people, especially some groups of feminists, might perceive stereotypical roles of women and motherhood as restrictive and negative, one does not get the sense that those stereotypes have a negative impact either on the rabinas or their work. On the contrary, all of them recognized their femininity as the distinct characteristic that enables them to better perform their roles as rabinas; thus, the same stereotypes that might prevent women's advancement in other workplaces do not impede it within these congregations. All the rabinas are proud to be women, because they 
understand the value they bring to the rabbinate through their feminine attributes, a value recognized not only by their congregations, but by their rabino partners.

The relationship rabinas have with their respective rabino partners plays a crucial part in the rabinas' leadership role within their congregations. Most of the rabinos highlighted the advantages of having a rabina working with them, noting that women can do things that they, as men, cannot. Clearly, they believe that the gendered division of tasks is necessary to better serving their congregations. However, it is important to note that only one rabino recognized that while his rabina partner's discourse is different from his, he does not see her as a woman, but as a rabbi. Despite the fact that for this rabino, gender does not play a role in their relationship, his rabina partner insisted that gender does play a role in the work she performs, remarking on the different things she, as a woman and from her feminine side, can do within the congregation.

Still, some questions - like whether certain tasks were only performed by rabinos - were not directly addressed, and were always excused by some category of "seniority." Senior rank was used to justify certain practices (such as ceremonies that would be performed by rabinas but are not), within the congregation, especially those practices, ceremonies, and tasks that could be performed by rabinas as well. This seemed to me to be an issue of both, rabinos and rabinas, but also of the congregation, which is still married to traditionally established practices within the congregation. Since rabinas are a fairly new phenomenon, the image of a rabino leader still endures.

The stereotypical role of women in Latin America and within traditional Judaism actually helped rabinas construct a new identity, one in which they could utilize feminine 
attributes of caregiving and nurturing with their congregations. By performing tasks related to their femininity and womanhood, they become the "mothers" of the congregation and kind of congregational "wives" to their rabino partners. Despite the generational differences among the group of rabinas I interviewed and their diverse personal backgrounds, they all embrace the traditional role of women and the attributes related to that role, such as femininity, caring, educating, nurturing, and being sensitive to issues that men cannot or do not understand. These attributes enable them to lead and become role models for other women and young girls in their congregations. Moreover, because of these attributes and their personal traits, the rabinas are respected and recognized in non-Jewish frameworks as well. By embracing the traditional attributes and roles of women in Judaism and Latin America, what the rabinas are doing, I believe, is establishing a new stereotype of independent women in religious leadership roles.

As I began my research, I realized I had predetermined notions about the rabinas; as I came to know them better, I realized those conceptions were not totally correct. As humans, we tend to categorize people according to our personal standards of propriety for actions or behaviors. One lesson I gained from this experience is that while a person's general characteristics might incline us to place them in a specific category culturally or socially, there are many variables unknown to us that would alter that categorization. When I personally met the rabinas, I was expecting to find seven feminists; instead, I found only two who defined themselves as the Jewish feminist that in the United States sought for women's ordination. Although the remaining five perform the same activities and advocate for the same rights that feminist women rabbis in the United States enjoy, 
these rabinas do not consider themselves feminist. Instead, they understand their fight for equality to be a feminine fight; one that needs to be fought alongside men and achieves equality by considering the similarities and differences between women and men.

I do not feel it is necessary to label this group of women as feminist or antifeminist, since both are opposite extremes on a spectrum that is still not completely understood in Latin America the same way is in the United States and Europe. These women defy simple categorization; therefore I can only define them as what they are: rabinas who, through their femininity and womanhood, are able to transmit to others their knowledge, faith, and passion for Conservative Judaism.

While this study contributes to our understanding of the gendered distribution of tasks within Conservative congregations in Latin America, it does have its limitations. This study was carried out only within Latin American Conservative Congregations in which rabinas are currently working; therefore, I cannot generalize my findings to all Conservative congregations in Latin America. Analía Bortz worked alongside her husband Rabino Mario Karpuj in a congregation in Santiago de Chile, and the Paraguayan Rabina Sandra Kochmann worked in a congregation in Rio de Janeiro, thus future studies should include these Conservative congregations as well as others which had never employed a rabina. Additional study could reveal the reasons behind the low number of ordained rabinas as well as the lack of rabinas working in Latin American Conservative congregations. Further study of characteristics and customs of other Conservative congregations in the region will facilitate this understanding. 
It is important to bear in mind that the gendered distribution of tasks in the observed Conservative Congregations is not a negative thing. On the contrary, it enables rabinas to perform their work in a manner that is appreciated and well received by all in their respective congregations. Despite the limitations of this research, this study provides a starting point, raising questions for further research. There are twelve Latin American rabinas working in congregations of Latin America, Israel, and the United States. Possibilities for further research include: a comparison between the rabinas working in Latin America and those working outside the region to determine how socio-cultural context influences the way they define themselves and how they perform their tasks as rabinas; an investigation into whether Conservative congregations outside Latin America are gendered; what it means for the rabinas working there; and what are the different conditions of rabinas working outside of Latin America. As more Latin American women pursue rabbinical careers, gendered congregations will be an ongoing issue that prompts two questions: Should rabbinic positions in Conservative Latin America be gendered? Or should Conservative Congregations in Latin America degenderize rabbinical positions?

Notwithstanding the many questions this study leaves open to further research, as far as this thesis is concern, I have proven that rabinas, as Jewish Conservative Latin American women, embrace their femininity and womanhood and use these characteristics to better serve their congregations. The division of tasks within these congregations is gendered; however, the fact that the rabinas embrace the traditional roles of women does not undermine their work. On the contrary, as mothers, caring for and nurturing their children, the rabinas educate new generations and lead from their feminine side, 
presenting a new model of the independent woman in Jewish Conservative Latin America, each of them becoming an Imah on the Bimah: woman, mother, and leader. 


\section{BIBLIOGRAPHY}

Abassi, Jennifer, and Sheryl Lutjens. "Theories, Themes, and the Realities of Gender in Latin America." In Rereading Women in Latin America and the Caribbean, edited by Jennifer Abassi and Sheryl Lutjens, 1-16. Lanham, Maryland: Rowman and Littlefield Publishers, Inc., 2002.

Acker, Joan. "From Sex Roles to Gendered Institutions." Contemporary Sociology, Vol. 21, No. 5 1992: 565-569.

Acker, Joan. "Hierarchies, Jobs, Bodies: a Theory of Gendered Organizations." Gender and Society, vol. 4, No. 2, June 1990: 139-158.

Adler, Rachel. Engendering Judaism: An Inclusive Theology and Ethics. Philadelphia, PA: The Jewish Publication Society, 1998.

Adler, Rachel. "The Jew who Wasn't There: Halakhah and the Jewish Woman." In On Being a Jewish Feminist, edited by Susannaha Heschel, 12-26. New York: Schocken Books, 1983.

Agosín, Marjorie. Talking Root: Narratives of Jewish Women in Latin America. Athens, $\mathrm{OH}$ : Ohio University Center for International Studies, 2002.

Alfred, Kolatch. The Jewish Book of Why. New York, NY: Jonathan David Publishers, 1995.

Alpert, Rebecca T. "Reconstructionist Judaism." In Encyclopedia of Religion, edited by Lindsay Jones, 7635-7640. Detroit: Macmillan Reference USA, 2005.

Ariel, David. What do Jews Believe? The Spiritual Foundations of Judaism. New York, NY: Schocken Books, 1995.

Baril, Gabriel. Seminario Rabínico Latinoamerican Marshall T. Meyer. n.d. http://www.seminariorabinico.org.ar/nuevoSite/website/ (accessed September 27, 2010).

Barrancos, Dora. Mujeres: Entre la Casa y la Plaza. Buenos Aires, Argentina: Ed. Sudamericana, 2008.

Baskin, Judith. "Four Approaches to Women and the Jewish Experience." In Women and Judaism, edited by Frederick Greenspahn, 1-22. New York, NY: New York University Press, 2009. 
Baskin, Judith. Women in Medieval Christina Europe, Early Modern Period, and In Modern Central and Western Europe. Vol. 21, in Encyclopedia Judaica, edited by Michael Berenbaum and Fred Skolnik, 170-180. Detroit: Macmillan Reference USA, 2007.

Beit-Halachmi, Rachel Sabath. "The Changing Status of Women in Liberal Judaism: a Reflective Critique." In Judaism and the Challenges of Modern Life, edited by Moshe Halbertal and Donniel Hartman, 74-84. New York, NY: Continuum, 2007.

Belucci, Mabel. "El Movimiento de Madres de Plaza de Mayo." In Historia de las Mujeres in la Argentina Siglo XX, edited by Fernanda Gil Lozano, Valeria Silvina Pita and María Gabriela Ini, 267-285. Buenos Aires: Taurus, 2000.

Berger, Shulamith. "Tehines: a Brief Survey of Women's Prayers." In Daughters of the King: Women and the Synagogue, edited by Susan Grossman and Rivka Haut, 7283. Philadelphia: The Jewish Publication Society, 1992.

Bernard, Jessie. The Future of Motherhood. New York, NY: Dial Press, 1974.

Bidegain, Ana María. Participación y Protagonismo de las Mujeres en la Historia del Catolicismo Latinoamericanos. Buenos Aires, Argentina: Editorial San Benito, 2009.

Bowden, Peta, and Jane Mummery. Understanding Feminism. Stocksfield: Acumen, 2009.

Bronstein, Guillermo. "Reaching Out in South America." In A Century of Commitment: One Hundred Years of the Rabbinical Assembly, by Robert E. Fierstien, 238-240. New York, NY: The Rabbinical Assembly, 2000.

Caplan, Paula. "Mothers, Judaism, and True Honor." In Celebating the lives of Jewish Women: Patterns in a Feminist Sampler, edited by Rachel Josefowitz Siegel and Ellen Cole, 39-44. New York, NY: The Harrington Park Press, 1997.

Chant, Sylvia, and Nikki Craske. Gender in Latin America. New Brunswick, New Jersey: Rutgers University Press, 2003.

Chemen, Silvina. "Contemporary Reflection on the Story of Parashat Pinchas." In The Torah: A Women's Commentary, edited by Tamara Cohn Esquenazi and Andrea Weiss, 985-986. New York: URJ Press and Women of Reform Judaism, 2008.

Chodorow, Nancy. The Reproduction of Mothering. Los Angeles, CA: University of California Press, 1978. 
Christiane, Alsop. "Home and Away: Self-Reflexive Auto-/Ethnography." Forum Qualitative Sozialforschung / Forum: Qualitative Social Research, September, 2002: 20-37.

Cohen, Shaye J. D. "Purity and Piety: The Separation of the Menstruant from the Sancta." In Daughters of the King: Women and the Synagogue, edited by Susan Grossman and Rivka Haut, 102-115. Philadelphia: The Jewish Publication Society, 1992.

Cohn-Sherbok, Dan. Jewish Mysticism: an Anthology. Rockport, MA: Oneworld Publications, 1995.

—. Modern Judaism. New York, NY: St. Martin's Press Inc., 1996.

Craske, Nikki. Women and Politics in Latin America. Cambridge, United Kingdom: Polity Press, 1999.

Daly, Mary. Gyn/Ecology: The Metaethics of Radical Feminism. Boston, MA: Beacon, 1978.

Dashefsky, Arnold, Sergio DellaPergola, and Ira Sheskin. Current Jewish Population Report: Succersor to the Population Articles from the American Jewish Book. Data Bank, Connecticut, CT: Berman Institute North American Jewish Data Bank University of Connecticut, 2010.

Daum, Annette. "Language and Liturgy." In Daughters of the King: Women and the Synagogue, edited by Susan Grossman and Rivka Haut, 182-202. Philadelphia: The Jewish Publication Society, 1992.

Davis, Moshe. The Emergence of Conservative Judaism: The Historical School in 19th Century America. Philadelphia, PA: The Jewish Publication Society of America, 1963.

DevArt. Masorti Olami. 2010. http://www.masortiworld.org/ (accessed Novemeber 24, 2010).

DiQuinzio, Patrice. The Impossibility of Motherhood: Feminism, Individualism, and the Problem of Mothering. New York, NY: Routledge, 1999.

Elazar, Daniel J., and Rela Mintz Geffen. The Conservative Movement in Judaism: Dilemmas and Opportunities. Albany, NY: State University of New York Press, 2000.

Elizalde, Teresa de. Un Dia en la Vida de 24 Mujeres Argentinas. Buenos Aires, Argentina: Aguilar, 2009. 
Elkin, Judith Laikin. Jews of the Latin American Republics. Chapel Hill, NC: The University of North Carolina Press, 1980.

Elkin, Judith Laikin. "The Evolution of Latin American-Jewish Communities: Retrospect and Prospect." In The Jewish Presence in Latin America, edited by Judith Laikin Elkin and Gilbert Merkx, 309-323. Winchester, MA: Allen \& Unwin Inc., 1987.

—. The Jews of Latin America. New York, NY: Holmes and Meier Publishers Inc., 1998.

Femenías, María Luisa, ed. Perfiles del Feminismo Iberoamericano, V.2. Buenos Aires, Argentina: Catálogos, 2005.

Firestone, Shulamit. The Dialectic of Sex. New York, NY: William Morrow, 1970.

Fishman, Sylvia Barack. "Women's Transformation of Contemporary Jewish Life." In Women and Judaism, edited by Frederick E. Greenspahn, 182-195. New York, NY: New York University Press, 2009.

Freedman, Jane. Feminism. Philadelphia, PA: Open University Press, 2001.

Freeze, ChaeRan. Women in Eastern Europe in the 19th and 20th century. Vol. 21, in Encyclopedia Judaica, edited by Michael Berenbaum and Fred Skolnik, 180-183. Detroit: Macmillan Reference USA, 2005.

Freidenreich, Harriet Pass. "How Central Jewish European Women Confronted Modernity." In Women and Judaism, edited by Frederick E. Greenspahn, 131152. New York, NY: New York University Press, 2009.

Friedan, Betty. The Feminist Mystique. New York, NY: Dell, 1963.

Fuchs, Esther. "Jewish Feminist Approaches to the Bible." In Women and Judaism, edited by Frederich Greenspahn, 25-40. New York, NY: New York University Press, 2009.

Gargallo, Francesca. "El Feminismo Múltiple: Practicas e Ideas Feministas en Latinamerica." In Perfiles del Feminismo Iberoamericano, Vol.I, edited by María Luisa Femenías, 103-129. Buenos Aires, Argentina: Catalogos S.R.L., 2002.

Geller, Laura. "From Equality to Transformation: The Challenge of Women's Rabbinic Leadership." In Gender and Judaism: The Tranformation of Tradition, edited by T. M. Rudavsky, 243-254. New York, NY: New York University Press, 1995.

Goldman, Karla. "When the Women Came to Shul." In Judaism since Gender, edited by Miriam Peskowitz and Laura Levitt, 57-61. New York, NY: Routledge, 1997. 
Goldman, Karla. "Women in Reform Judaism: Between Rhetoric and Reality." In Women Remaking American Judaism, edited by Riv-Ellen Prell, 109-133. Detroit: Wayne State University Press, 2007.

Golinkin, David, and Michael Panitz. Conservative Judaism. Vol. 5, in Encyclopedia Judaica, edited by Michael Berenbaum and Fred Skolnik, 171-177. Detroit: Macmillan Reference USA, 2005.

Gordis, Robert. "The Ordination of Women: a History of the Question." Judaism, issue 129, vol 33, n1, winter 1984: 6-12.

Gottlieb, Rabbi Lynn. "Woman Rabbi in Spiritual Leadership." In Women and Judaism, edited by Rabbi Malca Drucker, 31-56. Westport, Connecticut: Praeger Publishing, 2009.

Greenberg, Blu. On Women and Judaism: A View from Tradition. Philadelphia, PA: The Jewish Publication Society of America, 1981.

Greenspahn, Frederick E., ed. Women and Judaism: New Insights and Scholarship. New York, NY: New York University Press, 2009.

Grossman, Susan. "Women and the Jerusalem Temple." In Daughters of the King: Women and Synagogue, edited by Susan Grossman and Rivka Haut, 15-37. Philadelphia: The Jewish Publication Society, 1992.

Guy, Donna. "True Womanhood in Latin America." Journal of Women's History, 2002, Vol 14, No. 1 (Spring): 170-173.

Hall, Stuart. "Cultural Identity and Diaspora." In Identity, Community, Cultural Differences, edited by Jonathan Rutherford, 200-243. London: Lawrence and Wishart, 1990.

Hammersley, Martyn, and Paul Atkinson. Ethnography: Principal in Practices. New York, NY: Routledge, 2007.

Hauptman, Judith. "Women and the Conservative Synagogue." In Daughters of the King: Women and the Synagogue, edited by Susan Grossman and Rivka Haut, 158-181. Philadelphia: The Jewish Publication Society, 1992.

Hauptman, Judith. "Women and the Jewish Law." In Women and Judaism, edited by Frederick E. Greenspahn, 64-87. New York, NY: New York University Press, 2009. 
Haut, Irwin. "Are Women Obligated to Pray?" In Daughters of the King: Women and the Synagogue, edited by Susan Grossman and Rivka Haut, 88-101. Philadelphia: The Jewish Publication Society, 1992.

Haut, Rivka. "Women's Prayer Groups and the Orthodox Synagogue." In Daughters of the King: Women and the Synagogue, edited by Susan Grossman and Rivka Haut, 135-157. Philadelphia: The Jewish Publication Society, 1992.

Hawthorne, Sian. "Gender and Religion: History of the Study." In Encyclopedia of Religion, edited by Lindsay Jones, 3310-3318. Detroit: Macmillan Reference USA, 2005.

Heschel, Susannah. "Feminism." In Encycopledia Judaica, edited by Michael Berenbaum and Fred Skolnik, Vol 6, 752-757. Detroit: Macmillan Reference USA, 2007.

Hirsch, Richard. "Reconstructionism." In Encyclopedia Judaica, Vol 17, edited by Michael Berenbaum and Fred Skolnik, 146-149. Detroit: Macmillan Reference USA, 2007.

Holvino, Evangelina. "Intersections: The Simultaneity of Race, Gender and Class in Organization Studies." Gender, Work, and Organization 17, no. 3 (May 2010): 248-277.

Hyman, Paula E. "Looking to the Future: Conclusions." In Dughters of the King: Women and the Synagogue, edited by Susan Grossman and Rivka Haut, 297-305. Philadelphia: The Jewish Publication Society, 1992.

Ilan, Tal. Women in Post-Biblical and Talmudic Period. Vol. 21, in Encyclopedia Judaica, edited by Michael Berenbaum and Fred Skolnik, 161-165. Detroit: Macmillan Reference USA, 2007.

Jaquette, Jane. The Women's Movement in Latin America. Coulder, Colorado: Westview Press, Inc., 1991.

Joseph, Norma Baumel. "Mehitzah: Halakhic Decisions and Political Consequences." In Daughters of the King: Women and the Synagogue, edited by Susan Grossman and Rivka Haut, 116-133. Philadelphia: The Jewish Publication Society, 1992.

Juschka, Darlene M. "Gender." In The Routledge Companion to the Study of Religion, edited by John Hinnells, 229-242. New York, NY: Routledge, 2005.

Kaplan, Dana Evan. Reform Judaism. Vol. 17, in Encyclopedia Judaica, edited by Michael Berenbaum and Fred Skolnik, 165-183. Detroit: Macmillan USA, 2007.

Katz, Steven. Jewish Ideas and Concepts. New York, NY: Schocken Books, 1977. 
Katzburg, Nethaniel. Orthodoxy. Vol. 15, in Encyclopedia Judaica, edited by Michael Berenbaum and Fred Skolnik, 493. Detroit: Macmillan Reference USA, 2007.

King, Ursula. Gender and Religion: an Overview. Vol. 5, in Encyclopedia of Religion, Second Edition, edited by Lindsay Jones, 3296-3310. Detroit: Macmillan Reference USA, 2005.

Kinser, Amber. Motherhood and Feminism. Berkeley, CA: Seal Press, 2010.

Kolatch, Alfred. The Jewish Book of Why. New York, NY: Jonathan David Publishers, 1995.

Korzenik, Emily Faust. "On Being a Rabbi." In Daughters of the King: Women and the Synagogue, edited by Susan Grossman and Rivka Haut, 250-253. Philadelphia: The Jewish Publication Society, 1992.

Leacock, Eleonor. "Women, Development, and Anthropological Facts and Fictions." Latin American Perspectives, Winter/Spring 1977: 8-17.

Lesser, Jeffrey, and Raanan Rein. "Challenging Particularity: Jews as a lense on Latin American Ethnicity." Latin American and Caribbean Ethnic Studies 1, no. 2 (2006): 259-263.

Lesser, Jeffrey, and Raanan Rein. "Introduction." In Rethinking Jewish Latin America, by Jeffrey Lesser and Raanan Rein, 1-21. New Mexico: University of New Mexico Press, 2008.

Levine Melammed, Renée. Women in Medieval Islamic World and Spain. Vol. 21, in Encyclopedia Judaica, edited by Michael Berenbaum and Fred Skolnik, 165-170. Detroit: Macmillan Reference USA, 2007.

Levine Melammed, Renée. "Women in Medieval Jewish Societies." In Women and Judaims, edited by Frederick E. Greenspahn, 91-115. New York, NY: New York University Press, 2009.

Levine, Robert. "Adaptive Strategies of Jews in Latin America." In The Jewish Presence in Latin America, edited by Judith Laikin Elkin and Gilbert Merkx, 71-84. Winchester, MA: Allen \& Unwin Inc., 1987.

Liebman, Charles. "Orthodox Judaism." In Encyclopedia of Religion, Second Ed., edited by Lindsay Jones, 6898-6907. Detroit: Macmillan Reference USA, 2005.

Liebman, Seymour B. "Understanding Latin American Jewry." Reconstrucctionist, March 3, 1967: 21-26. 
Maier, Elizabeth. "Concluding Reflections: Renegotiating Gender in Latin America and the Caribbean." In Women's Activism in Latin America and the Caribbean: Engendering Social Justice, Democratizing Citizenship, edited by Elizabeth Maier and Nathalie Lebon, 337-351. Piscataway, NJ: Rutgers University Press, 2010.

Malka, Drucker Rabbi. Women and Judaism. Westport, CT: Praeger Publishing, 2009.

Merkx, Gilbert W. "Jewish Studies as a Subject of Latin American Studies." In The Jewish Presence in Latin America, edited by Judith Laikin Elkin and Gilbert Merkx, 3-10. Winchester, MA: Allen \& Unwin, Inc., 1987.

Meyer, Michael. "Reform Judaism." In Encyclopedia of Religion, Second Ed., edited by Lindsay Jones, 7665-7673. Detroit: Macmillan Reference USA, 2005.

Meyer, Rabbi Marshall T. "Una década del judaismo conservador en Latinoamerica." In Comunidades Judias de Latinoamerica, edited by Jose Isaacson and Santiago Kovadloff, 182-196. Buenos Aires, Argentina: Editorial Candelabro, 1970.

Meyers, Carol. Women in Biblical Period. Vol. 21, in Encyclopedia Judaica, edited by Michael Bernbaum and Fred Skolnik, 156-151. Detroit: Macmillan Reference USA, 2007.

Millen, Rochelle. "Her Mouth is Full of Wisdom: Refelctions on Jewish Feminist Theology." In Women Remaiking American Judaism, edited by Riv-Ellen Prell, 27-49. Detroit: Wayne State University Press, 2007.

Miller, Francesca. Latin american Women and the Search for Social Justice. Hanover, NH: University Press of New England, 1991.

Mintz, Anne. "Should Women be Conservative Rabbis?" Sh'ma: a Journal of Jewish Responsibility, 9/164, December 1978: 25-29.

Molyneux, Maxine. "Mobilization without Emancipation? Women's Interest: The State and Revolution in Nicaragua." Feminist Studies, 1985: 227-254.

Monk, Abraham. "Latin American Jewry." Reconstructionist, December 12, 1958: 14-18.

Monson, Rela Geffen. "The Impact of the Jewish Women Movement on the American Synagogue: 1972-1985." In Daughters of the King: Women and the Synagogue, edited by Susan Grossman and Rivka Haut, 226-236. Philadelphia: The Jewish Publication Society, 1992.

Montesino, Sonia. "Understanding Gender in Latin America." In Gender's Place, Feminist Anthropoligies of Latin America, edited by Rosario Montoya, Lessie Jo Frazier and Janice Hurtig, 228-273. New York, NY: Palgrave Macmillan, 2002. 
Montoya, Rosario, Lessie Jo Frazier, and Janise Hurtig. Gender's Place: Feminist Antrhopolgies of Latin America. New York, NY: Palgrave Macmillan, 2002.

Nadell, Pamela. "Bridges to a "Judaism Transformed by Women's Wisdom": The First Genreation of Women Rabbis." In Women Remaking American Judaism, edited by Riv-Ellen Prell, 211-228. Detroit: Wayne State University Press, 2007.

Nadell, Pamela. "Conservative Judaism." In Encyclopedia of Religion, Second Ed., edited by Lindsay Jones, 1957-1966. Detroit: Macmillan Reference USA, 2005.

Nadell, Pamela. "Women and American Judaism." In Women and Judaism, edited by Frederick E. Greenspahn, 155-181. New York, NY: New York University Press, 2009.

Nadell, Pamela. Women in North America. Vol. 21, in Encyclopedia Judaica, edited by Michael Berenbaum and Fred Skolnik, 183-186. Detroit: Macmillan Reference USA, 2007.

—. Women who would be Rabbis: a History of Women's Ordination 1889-1985. Boston,

Navarro, Marysa. "Against Marianism." In Gender's Place:Feminist Anthropologies of Latin America, edited by Rosario Montoya, Leslie Jo Frazier and Janise Hurtig, 257-272. New York, NY: Palgrave MacMillan, 2002.

Navarro, Marysa. "Women in Pre-Columbian and Colonial Latin America and the Caribbean." In Women in Latin America and the Caribbean: Restoring Women $t$ History, by Navarro Marysa and Virginia Sánchez Korrol, 5-58. Bloomington, IN: Indiana University Press, 1999.

Navarro, Marysa, and Catharine Stimpson, . Cambios Sociales, Económicos y Culturales. Buenos Aires, Argentina: Fondo de Cultura Económica de Argentina, 2000.

Navarro, Marysa, and Virgina Sánchez Korrol. Women in Latin America and the Caribbean. Bloomington, IN: Indiana University Press, 1999.

Novak, David. "Women in the Rabbinate?" Judaism, issue 129, vol 33, n1, winter 1984: 39-49.

Pearlmutter, Fishel A. "The Case for Women Rabbis." Judaism, issue 129, vol 33, n1, winter 1984: 50-53.

Pescowitz, Miriam, and Laura Levitt, Judaism since Gender. New York, NY: Routledge, 1997. 
Plascow, Judith. "The Jewish Feminist: Conflict in Identities." In The Jewish Woman: New Perspectives, edited by Elizabeth Koltun, 3-10. New York, NY: Schocken Books, 1976.

Plaskow, Judith. Standing Again at Sinai: Judaism from a Feminist Perspective. New York, NY: Harper Collins Publishers, 1989.

Prell, Riv-Ellen. "Introduction: Feminism and the Remaking of American Judaism." In Women Remaking American Judaism, edited by Riv-Ellen Prell, 1-23. Detroit: Wayne State University Press, 2007.

Rabbinical Assembly Website. n.d. http://www.rabbinicalassembly.org/indexnf.html (accessed Novemeber 24, 2009).

Rabinowitz, Mayer. "An Advocate's Halakhic Responses on the Ordination of Women." Judaism 33, no. 129 (Winter 1984): 55-66.

Rackman, Emanuel. Developments in Modern Orthodoxy. Vol. 15, in Encyclopedia Judaica, edited by Michael Berenbaum and Fred Skolnik, 497-499. Detroit: Macmillan Reference USA, 2007.

Raphael, Melissa. "Gender and Religion: Gender and Judaism." In Encyclopedia of Religion, Second Edition, edited by Lindsey Jones, 3350-3356. Detroit: Macmillan Reference USA, 2005.

Reguer, Sara. "Women and the Synagogue in Medieval Cairo." In Daughters of the King: Women and the Synagogue, edited by Susan Grossman and Rivka Haut, 50-57. Philadelphia: The Jewish Publication Society, 1992.

Rich, Adrianne. Of Woman Born" Motherhood as Experience and Isntitution. New York, NY: W. W. Norton and Company Inc., 1986.

Rosenmann, Marcos Roitman. Pensar América Latina: El Desarrollo de la Sociología Latinoamericana. Buenos Aires, Argentina: Consejo Nacional de Ciencias Sociales, 2008.

Rubin Schwartz, Shuly. "The Tensions that Merit our Attention: Women in Conservative Judaism." In Women Remaking American Judaism, edited by Riv-Ellen Prell, 153-179. Detroit: Wayne State University Press, 2007.

Ruddick, Sara. Maternal Thinking: Toward a Politics of Peace. Boston, MA: Beacon Press, 1995.

Safa, Helen. "Economic Restructuring and Gender Subordination." In Rereading Women in Latin America ad the Caribbean, edited by Jennifer Abbassi and Sheryl 
Lutjens, 43-79. Lanham, Maryland: Rowman and Littlefield Publishers, Inc., 2002.

Safa, Helen, and Cornelia Butler Flora. "Production, Reproduction, and the Polity: Women's Strategic and Practical Gender Issues." In Americas: New Interpretative Essays, edited by Alfred Stepan, 109-136. New York, NY: Oxford University Press, 1992.

Safrai, Hannah. "Traditional Judaism and the Feminist Challenge." In Judaism and the Challenges of Modern Life, edited by Moshe Halbertal and Donniel Hartman, 7359. New York, NY: Continuum, 2007.

Safrai, Hannah. "Women and the Ancient Synagogue." In Daughters of the King: Women and the Synagogue, edited by Susan Grossman and Rivka Haut, 38-49. Philadelphia: The Jewish Publication Society, 1992.

Sánchez Korrol, Virginia. "Women in Nineteenth- and Twentieth-Century Latin America and the Caribbean." In Women in Latin America and the Caribbean: Restoring Women to History, by Marysa Navarro and Sánchez Korrol Virginian, 59-106. Bloomington, IN: Indiana University Press, 1999.

Schers, David. "Culture, Identity, and Community." In The Jewish Presence in Latin America, edited by Judith Laikin Elkin and Gilbert Merkx, 285-296. Winchester, MA: Allen \& Unwin Inc., 1987.

Schers, David, and Hadassa Singer. "The Jewish Communities of Latin America: Internal and External Factos in their Development." Jewish Social Studies, 1977, Vol. 39, Iss. 3: 241-258.

Scholz, Sally J. Feminism. New York, NY: Oneworld Publications, 2010.

Scott, Joan. "Gender: A Useful Category of Historical Analysis." American Historical Review, no. 91 (1986): 1053-1075.

Seidler-Feller, Chaim. "Mujeres Rabinas, Temor Masculino." Maj'shavot/ Pensamientos, Enero-Marzo 1989: 62-69.

Shalvi, Alic. "The Geopolitics of Jewish Feminism." In Gender and Judaism: The Tranformation of Tradition, edited by T. M. Rudavsky, 231-242. New York, NY: New York University Press, 1995.

Shaull, Richard. "Latin America: Three Responses to a New Historical Situation." Interpretation, 46 no 3 Jl 1992: 261-270. 
Shulman, Gail. "A Feminist Path to Judaism." In On Being a Jewish Feminist, edited by Susannah Heschel, 105-109. New York, NY: Schocken Books, 1983.

Sigal. Women of the Wall. n.d. http://womenofthewall.org.il/about (accessed January 5, 2011).

Simon, Rachel. Women in Modern Muslim World. Vol. 21, in Encyclopedia Judaica, edited by Michael Berenbaum and Fred Skolnik, 186. Detroit: Macmillan Reference USA, 2007.

Skorka, Abraham. "Half a Yovel of Rabbinical Service in Argentina." In A Century of Commitment: One Hundred Years of the Rabbinical Assembly, edited by Robert Fierstien, 241-242. New York, NY: The Rabbinical Assembly, 2000.

Smith, Mark K. "Infed." 1996. http://www.infed.org/biblio/b-nonfor.htm (accessed December 22, 2010).

Stepan, Alfred, ed. Americas: New Interpretative Essays. New York, NY: Oxford University Press, 1992.

Stevens, Evelyn. "Marianismo: The Other Face of Machismo in Latin America." In Female and Male in Latin America, edited by Ann Pescatello, 89-102. Pittsburg: University of Pittsburg Press, 1973.

Sylvia Chant, Nikki Craske. Gender in Latin America. New Brunswick, NJ: Rutgers University Press, 2003.

Szteinhendler, Shmuel. "The Rabbinical Assembly in Latin America." In A Century of Commitment: One Hundred Years of the Rabbinical Assembly, edited by Robert E. Fierstien, 234-238. New York, NY: The Rabbinical Assembly, 2000.

Taitz, Emily. "Women's Voices, Women's Prayers: European Synagogues in the Middle Ages." In Daughters of the King: Women and the Synagogue, edited by Susan Grossman and Rivka Haut, 58-71. Philadelphia: The Jewish Publication Society, 1992.

Theall, Michael, and Joseph Farrel. "Teaching and Learning." In Encyclopedia of Education, edited by James W. Guthrie, 2492-2501. Detroit: Macmillan Reference USA, 2002.

Umansky, Ellen. "Creating a Jewish Feminist Theology." In Weaving the Visions: New Patterns in Feminist Spirituality, edited by Judith Plaskow and Carol Christ, 187198. New York, NY: Harper Collins Publishers, 1989. 
Umansky, Ellen M., and Dianne Ashton. Jewish Women Spirituality: a Sourcebook. Waltham, Massachusetts: Brandeis University Press, 2009.

Unesco. "Latin American and the Caribbean Regional Report." Unesco. 2001. http://www.uis.unesco.org/TEMPLATE/pdf/ed2001/Amerique_latine_ENPDF.pd f (accessed July 26th, 2010).

Vitale, Luis. La Mitad Invisible de la Historia Latinoamericana: El Protagonismo Social de la Mujer. Buenos Aires, Argentina: Sudamericana/ Planeta S.A, 1987.

Weisberg, Dvora. "On Wearing Tallit and Tefillin." In Daughters of the King: Women and the Synagogue, edited by Susan Grossman and Rivka Haut, 282-283. Philadeplhia: The Jewish Publication Society, 1992.

Weisberg, Dvora. "Women and Torah Study in Aggadah." In Women and Judaism, edited by Frederick E. Greenspahn, 41-63. New York, NY: New York University Press, 2009.

Weissler, Chava. "The Mystical Spirituality of Eastern European Jewish Women." In Women and Judaism, edited by Frederick E. Greenspahn, 116-130. New York, NY: New York University Press, 2009.

Wessinger, Catherine, ed. Religious Institutions and Women's Leadership: New Roles Inside the Mainstream. Columbia, SC: University of South Carolina Press, 1996.

Wisse, Ruth R. "Women as Conservative Rabbis?" Commentary, Vol 68, n4, October $1797:$ 59-64.

Wurzurberg, Walter. Orthodoxy. Vol. 15, in Encyclopedia Judaica, edited by Michael Berenbaum and Fred Skolnik, 493-497. Detroit: Macmillan Reference USA, 2007.

Yepes, Enrique. Las Mujeres Latinoamericanas en la Búsqueda de de Transfromaciones Sociopolitcas. Brunswick, ME, April 2007.

Zadoff, Efraim, and Haim Avni. Latin America. Vol. 12, in Encyclopedia Judaica, edited by Michael Berenbaum and Fred Skolnik, 507-517. Detroit: MacMillan Reference USA, 2007.

Zohar, Zion. "Orthodox Judaism." In Worldmark Encyclopedia of Religious Practices, edited by Thomas Riggs, 462-468. Detroit: Thomson Gale, 2006.

Zucker, David. American Rabbis: Facts and Fiction. Northvale, NJ: Jason Aronson Inc., 1998. 